\title{
DESENVOLVIMENTO DE HORIZONTES SUPERFICIAIS DE SOLOS PODZOLICOS RELACIONADOS COM AS FORMAÇÕES CORUMBATAÍ E PIRAMBÓIA
}

\author{
HÉLIO DO PRADO
}

Orientador: Dr. ANTONIO CARLOS MONIZ

Dissertação apresentada a Escola Superior de Agricultura "Luiz de Queiróz", para a obtenção do título de Mestre em Agronomiaárea de concentração: Solos $\theta$ Nutrição de Plantas.

PIRACICABA

Estado de São Paulo - Brasil

Novembro - 1986 
Aos meus pais, tios, irmãos

e primos, ofereço

A minha esposa cleide, dedico 


\section{A G R R A D D E C C I M E N T O S}

- Ao Pesquisador Cientifico Dr. Antonio Carlos Moniz, chefe da Seção de Pedologia do Instituto Agronômico do Estado de São Paulo, nossa gratidão pela orientação dessa pesquisa.

- Ao Prof. Dr. José Humberto Barcelos, do Departamento de Geologia Geral e Aplicada do Instituto de Geociências Ciências Exatas da Universidade Estadual "Julio de Mesquita", campus de Rio Claro pela co-orientação do presente trabalho.

- Aoś pesquisadores Dr. Igo Fernando Lepsch.e Dr. Wanderley An tonio Tremocoldi, da Seção de Pedologia do Instituto Agronômico do Estado de São Paulo, pela pronta colaboração quando solicitados.

- Ao Prof. Dr. Armando Márcio Coimbra, do Departamento de Paleontologia e Estratigrafia do Instituto de Geociências da Universidade de são paulo, pelas idéias, sugestões e discussöes.

- A Profá. Drå Selma Simóes de Castro, do Departamento de Geografia da Faculdade de Filosofia e Ciências Humanas da Universidade de São Paulo, pelas discussões micromorfológicas.

- Ao Prof. Dr. José Luiz Ioriatti Demattê, chefe do Departamen to de Solos, Geologia e Fertilizantes da Escola Superior de Agricultura "Luiz de Queiróz", pelas sugestões e comentários. 
- Aos técnicos de laboratório Célia Beatriz Gonçalves, Soraya Maria de Oliveira, Cêlia Panzarin e Angelo'Brás Bresil, pela colaboração e dedicação durante a realização das anälises fí sicas e químicas nos laboratorios da Seção de Pedologia.

- Ao auxiliar agropecuário José da Silva Pinto filho, pela colaboração e dedicação durante a realizaçãodas análises mine ralógicas da fração argila no laboratório de mineralogia da Seção de Pedologia.

- A técnica de laboratório Maria Célia Zadra Schmidt, pelo auxílio nos trabalhos de laboratório e de processamento estatistico.

- Ao estudante de geologia Gervásio Koji Matsumoto, pela colaboração nos trabalhos de laboratório.

- Ao desenhista Sr. Hélio Neme, do Instituto Agronômico do Estado de são Paulo, pelo esmero nas confecções dos gráficos.

- A Empresa Brasileira de Pesquisa Agropecuária (EMBrapa), pe10 suporte financeiro.

- Ao Departamento de Geologia Geral e Aplicada do Instituto de Geologia e Ciencias Exatas da Universidade Estadual Paulista "Julio de Mesquita", campus de Rio Claro, pela cessão dos 1 a boratórios para execução das anālises granulométricas.

- Ao Instituto Agronômico do Estado de São Paulo, atravēs da Comissão de Orientação do Estudante de Pós-Graduação, pelo apoio recebido. 
- A Escola Superior de Agricultura. "Luiz de Queiróz", pela opor tunidade de realizar o Curso de Pós-Graduação. 
1. INTRODUÇÃo $\ldots \ldots \ldots \ldots \ldots \ldots \ldots \ldots \ldots \ldots \ldots \ldots$

2. Revis $\tilde{O}$ De Literatura $\ldots \ldots \ldots \ldots \ldots \ldots \ldots$

3. LOCALIZAÇÃo dA ÄREA ESTUdAdA .......... 09

4. MAteriats e MEtOdOS ................ 10

4.1. Materiais $\ldots \ldots \ldots \ldots \ldots \ldots \ldots \ldots \ldots$

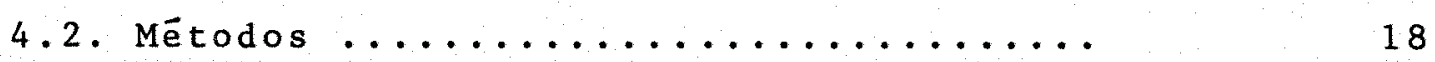

4.2.1. Anālise de laboratório ...... 18

4.2.1.1. Anāiises químicas .... 18

4.2.1.2. Análise granulométrica 20

4.2.1.3. Análise estatistica... 22

4.2.1.4. Análise de morfoscopia 23

4.2.1.5. Estudo minerais pesados $\ldots \ldots \ldots \ldots \ldots \ldots$

4.2.1.6. Análise micromorfológi ca $\ldots \ldots \ldots \ldots \ldots \ldots$ 2....... 23

4.2.1.7. Anālise mineralögica da fração argila .....

4.2.2. Método de traba1ho de campo ...

5. Resultados E discussão (ENCOSTA A) ...... 26

5.1. Encosta A ............... 26

5.1.1. Anälises químicas .......... 26

5.1.2. Anālise granulométrica $\ldots \ldots \ldots \quad 28$ 
5.1.3. Anālise estatistica ...

5.1.4. Descrição morfolögica ..

5.1.5. Anāitse de morfoscopia

5.1 .6 . Estudo dos minerais pesa

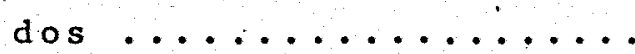

5.1 .7$. Ferro $\ldots \ldots \ldots \ldots \ldots \ldots$

5.2 . Encosta B ................... 64

5.2.1. Anälises químicas ......... 64

5.2.2: Anāilse granulomētrica ...... 65

5.2.3. Anāise estatistica ........ 66

5.2 .4$. Descrição morfolögica ....... 68

5.2.5. Análise de morfoscopia ...... 82

5.2 .6 . Estudo dos minerais pesados ... 85

5.2 .7$. Ferro $\ldots \ldots \ldots \ldots \ldots \ldots \ldots \ldots \ldots$

5.2.8. Anälise micromorfolögica .... 91

5.2.9. Anālise mineralögica da fração

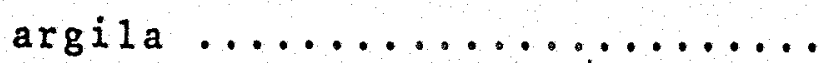

5.3. Comparação entre o arenito da Formação Pirambóia e o folhelho da Formação Corumbatai $\ldots \ldots \ldots \ldots \ldots \ldots \ldots \ldots$

5.3.1. Anälise granulomëtrica ..... 103

5.3 .2 . Anāise estatística $\ldots \ldots \ldots \ldots 108$

5.3.3. Análise de morfoscopia ....... 112

5.3.4. Estudo dos minerais pesados ... 115 
$v i i$

$P \Xi g$ ina

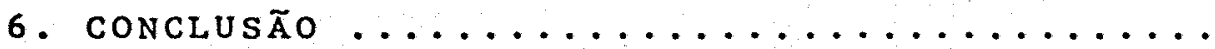

7. Literatura citada ..............

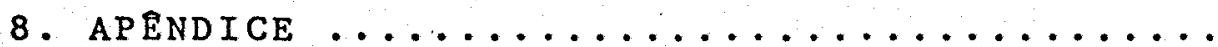

127 
DESENVOLVIMENTO DOS HORIZONTES SUPERFICIAIS DE SOLOS PODZOLICOS RELACIONADOS COM AS FORMAÇOES CORUMBATAI

E PIRAMBŌIA

Candidato: Hélio do Prado Orientador: Dr. Antonio Carlos Moniz

RESUMO

Duas encostas foram estudadas desde seus topos às posiçóes mais baixas do relevo. Nela ocorrem solos classi ficados como Podzölico Vermelho-Amarelo variação Laras (PVIs) nas partes mais elevadas e Podzölico Vermelho-Amarelo variação Piracicaba (PVp) nas mais baixas. o PVls relaciona-se com - arenito da Formação Pirambóia e o PVp com o folhelho da For mação corumbataí.

o objetivo deste trabalho foi verificar a causa do exagerado aumento do teor de argila do horizonte A para o horizonte B do PVp, tomando-se como hipötese que o horizonte superficial desse solo, localizado na parte inferior da encos ta e que tem mudança textural abrupta, recebeu maiores contri buições laterais dos sedimentos grosseiros, derivados do solo da Formação Pirambóia elou do solo dele derivado (PVIs), loca lizado na parte superior da encosta. Para isso foram: a) estu dadas as propriedades minera 10 gicas do PVp visando detectar a 
presença de descontinuidade litolögica, em função da possível contribuição de material grosseiro proveniente da Formação Pi rambóia; b) aplicados parâmetros estatísticos na interpretação da anālise granulométrica para o estudo da uniformidade do material de origem; c) realizados exames demorfoscopiados grãos de quartzo para auxiliar na determinação da procedência da areia do horizonte A do PVp.

Em ārea próxima a ambas encostas, por falta de mais dados na literatura, foram coletados amostras das rochas arenito e folhelho para se conhecer suas caracteristicas (gra nulométricas, mineralógicas da fração areia (pesados) e de morfoscopia, e depois comparar com as dos perfis.

os minerais pesados da fração areia por serem qualitativamente os mesmos, nas rochas (arenito e folhelho) e nos solos estudados, não serviram paraindicaruma possível con tribuição de areia no horizonte A do PVp a partir do arenito da Formação Pirambóia elou do solo dele derivado (PVls). os valores de arredondamento médio da areia do arenito da Formação Pirambóia, que são maiores que do folhelho da. Formação Co rumbataí, assemelham-se aos valores obtidos nos horizontes A e B do PVp, sugerindo que esses horizontes tiveram contribuição do arenito. 
$x i$

os dados referentes a descrição morfológica do PVp indicaram mosqueamento no topo do horizonte $B$, o que sugere ter ocorrido remoção de argila a partir da superfície pelo processo de ferrólise. Esse processo consiste na destruição de argilo-minerais no horizonte superficial e teve inicio pela re moção do ferro na forma bivalente devido as condições : rredutoras do meio ambiente.

os dados da descrição micromorfológica do hori zonte B 2 do PVp mostraram presença de argillans de iluviação, sugerindo translocação de argila do horizonte A para o B. 
DEVELOPMENT OF SUPERFICIAL PODZOLICS SOILS HORIZONS DERIVED FROM CORUMBATAI AND PIRAMBOIA FORMATIONS

Candidate: Hélio do Prado Adviser: Dr. Antonio Carlos Moniz.

SUMMARY

Two sequences of soils, along a moderate inclined slope, were studied in Corumbata $\mathbf{i}$ county, state of São Paulo, Brazil. The soils in the upslope were classified as Red Yellow Podzolic distrophic and alic moderate A horizon sandy/loam texture (PVIs) and in footslope as Red Yellow Podzolic alic moderate A horizon sandy/clay texture. The former is derivated from Pirambóia Formation sandstone and the latter from Corumbatai Formation shale.

The main objetive. was to determine the origin of the considerable textural change between $A$ and $B$ horizons in the PVp soil. The working hypothesis was that the parent material of this soil, on the footslope, was not homogeneous. The higher amount of sand it has in $A$ horizon was due in part the lateral constribution of soils and/or sandy sediments of Piramböia Formation which occour in the upslope. To carry out 
this study following analysis were performed:

a) Identification of heavy minerals in very fine sand of soil profiles to verify the occurance of any 1 ithologic descontinuity;

b) With the same purpose, morfoscopic studies of quartz in very fine sand;

c) Applied statistics parameters in the interpretation of granulometric analysis (mean, standard deviation, swekness and kurtosis) of very fine sand in study of uniformity of parent material.

Some studies on fresh sandstone and samples were performed due the lack of geologic 1iterauture data. The rock samples were collected in areas near the studied soils and the following analysis were performed: particle size distribution, heavy sand mineralogy and sand fraction morphoscopy. These data were compared with similar ones from the studied soils.

The study of sand fraction did not show any contribution from Piramboia sandstone in the A horizon of PVp soil. The heavy minerals of sand are similar both in Pirambóia sandstone and Corumbatai shale. The PVp soil is derived from the latter.

The values of roundness of very fine sand particles of Piramböia Formation sandstone are similar to the values found in $A$ and $B$ horizons of $P V p$ soil and higher than 
those found in Corumbataí Formation shales. This result indicated the A horizon as well as the B horizon had received contribution from the Pirambóia sandstone.

The data related to the morphologic description of the PVp soil presented mottles at the top of $B$ horizon suggesting clay remotion of surface by ferrolysis processes. This process is based on destruction of clay minerals from the surface horizon starting with iron remotion in the $\mathrm{Fe}^{2+}$ form due to environmental redution conditons.

The micromorphological study of B horizon of PVp showed illuviation of argillans suggesting some clay translocation from A to B horizon. 
1. INTRODUÇAOO

No levantamento pedolögico a nível de semidetalhe da quadrícula de São Carlos (PRADo et alii, 1981) foi constatada na região de Corumbataí (SP) a ocorrência de solos pertencentes as classes dos Podzólicos Vermelho-Amarelos que possuem mudança textural abrupta entre os horizontes A $e$ B. Tal solo correlaciona-se com o Podzólico Vermelho-Amarelo variação Piracicaba (COMISSÃO DE SOLOS, 1960), e apresenta hor zonte A moderado de textura arenosa sobrejacente ao horioznte B textural älico de textura argilosa. Foram selecionadas duas encostas, onde na parte mais alta do relevo ocorre o Podzólico Vermelho-Amarelo variação Laras (PVIs), derivado da Formação Pirambóia, e na posição mais baixa o Podzólico VermelhoAmarelo variação Piracicaba (PVp), derivado da Formação Corum bataí e que tem mudança textural abrupta.

o objetivo desse trabalho foi conhecer a origem do horizonte A do PVp, tomando-se como hipótese que o re- 
ferido horizonte recebeu contribuições das partes mais altas do relevo do arenito da Formação Pirambóia e/ou do solo dele derivado. Para isso foram feitos estudos:

a) mineralógicos da fração areia (pesados) visando detectar a presença de descontinuidade litolögica em função da possível contribuição de material grosseiro da Formação Piram bóia;

b) estatisticos na interpretação da anălise granulométrica pa ra o estudo de uniformidade do material de origem e,

c) de morfoscopia dos grãos de quartzo para auxiliar na deter minação de sua procedência. 


\section{REVISATO DE LITERATURA}

Entre os solos com horizonte B textural identificados pela comISST̃O DE SOLOS (1960) estão o Podzólico VeI melho-Amarelo variação Piracicaba ( $P V p)$ e o Podzólico Verme1ho-Amarelo variação Laras (PVIs). Segundo essa CoMISSÃo o ma terial de origem do PVp, solo que motivou a investigação do carāter abrüptico no presente estudo, é o folhelho da Formação Corumbataí e do PVIs o arenito da Formação Pirambóia. Entre as caracteristicas dos solos com horizonte B textural, destaca-se o teor de argila do horizonte A ser inferior ao do horizonte B e uma das explicações mais comuns é a migração de argila do horizonte A para o B, ou seja, a ocorrência do processo de "lessivage" ou argiluviação (BUOL et alii, 1973).

Estudando solos sob vegetação de floresta KARPACHEVSKI (1960), observou que a podzolização è acompanhada pelo processo de intemperismo dos minerais primärios e que a "lessivage" constitui a fase inicial da podzolização. 
(1959) verificou em solos desenvolvidos de granito e xisto,que a ausência de filmes de argila esta associada ao desaparecimen to de argilas micáceas e com aumento em gibbsita, devido a translocação e floculação de alumínio, silica e ferro.sIMONSON (1949) sugeriu como processos atuantes no Podzó1ico VermelhoAmarelo a formação de minerais de argila silicatada em grande profundidade e sua subsequente destruição e desaparecimento.

GAMBLE et alii (1966) estudando as relaçōes de origem e morfogenética dos horizontes superficiais arenosos de Podzólicos Vermelho-Amarelos (U1tissóis) da Carolina do Norte, encontrou uniformidade no valor médio da fração areia dos hori zontes A e B. Esses autores atribuiram ao horizonte A2 origem pedogenética e não por descontinuidade litológica.

Como explicações alternativas para o: fenómeno de acréscimo de argila em profundidade, tem-se:

a) degradação dos finos do horizonte superficial do material adensado por dissecação e formado pela ação da àgua que se movimenta lateralmente ao longo da encosta (MONIZ e BUOL, 1982).

b) destruição dos argilo-minerais no horizonte A provocado por condições de alternância de fases de oxidação e redução. Nes sa ültima fase o ferro na forma bivalente é solubilizado e substitui parte das bases trocāveis. Na fase subsequente de oxidação o ferro bivalente passa para a forma trivalente, 
produzindo hidrogênio que o substitui no complexo sortivo saturando-o. o hidrogênio no complexo sortivo por ser insta vel é substituído pelo alumínio que é liberado por destruição da rede cristalina da argila. Assim as argilas são destruida pelo processo de ferrólise (BRINKMAN, 1969/70).

c) redução do ferro como agente cimentante em superfície, dispersão e eluviação de argila (LEPSCH et alii, 1977).

d) remoção dos finos ao longo da encosta (PENCK, 1953).

e) enriquecimento de bases e sỉlica na solução do solo (CARVALHO et alii, 1983).

f) destruição de argila no epipedon pelo processo de intemperismo, erosão superficial seletiva e sedimentação de material superficial de textura grosseira. (EUA, 1986),

g) coluviamento de material grosseiro coincidente com o horizonte A: (QUEIROZ NETO, 1977).

A descontinuidade litolōgica pode ser determi nada pela anālise mecânica (MARSHALL and HASEMAN, 1942 ; GAMBLE, 1966), através do estudo da distribuição dos separados do solo no perfil, considerando-se especialmente dados da fra ção areia (valor médio, grau: de seleção, assimetria e curtose). Esses parâmetros podem ser determinados graficamente ou matematicamente (KRUMBEIN and PETTIJOHN, 1938). 
BREWER (1968) citou a reduzida iluviação de argila no Podzólico Vermelho-Amarelo e justificou o incremento de argila no horizonte B à própria heterogeneidade do mate rial de origem, ou mesmo ao intemperismo diferenciado entre os horizonte A e B.

A gênese da transição abrupta entre os horizontes $A$ e $B$ do Bruno Não-Calcico foi explicada por RESENDE (1983), pela contribuição do processo de "lessivage" com dissolução dos finos, remoção lateral de argila por um processo seletivo quanto ao tamanho de particulas e pelo processo de ferrölise (BRINKMANN, 1979).

A importância do estudo mineralógico da fração areia (pesados) tem sido destacada por muitos autores por ser ütil no estudo de uniformidade de material de origem. CAMARGO e VAGELER (1937), salientaram a importância da mineralo gia e PETTIJOHN (1941) propôs uma sequência de minerais resis tentes ao processo de intemperismo, classificando como mais resistentes turmalina, zirconita, monazita e granada, como me nos resistentes biotita, apatita, ilmenita, magnetita, estaurolita, cianita e epidoto. MARSHALL (1941) e MARSHALL e HASEMAN (1945) possivelmente foram os primeiros a considerar a zirconita como mineral indice partindo da suposição de que mi nerais resistentes permanecem constantes no desenvolvimento do solo. 
A relação zircão/turmalina da fração areia é considerada como mineral-indice para avaliar uniformidade de material de origem e värios autores utilizaram essa relaçäo (DEMATTE, 1978), (GALHEGO, 1977), (LỔO, 1971), (BAHIA, 1973). WU e SOARES (1974) identificaram a estaurolita como sendo o mineral predominante no arenito da Formação Pirambóia.

DECHEN (1979) estudando o Podzōlico VermelhoAmarelo variação Piracicaba, verificou que a fração areia é constituída predominantemente de quartzo, seguido de mica e feldspato em menor quantidade.

os dados relativos a granulometria dos sedimentos, em geral, não apresentam distribuição normal e um estudo detalhado desses materiais deve incluir além da granulometria dados quantitativos sobre composição mineralógica. Devido à grande quantidade de dados obtidos no estudo detalhado dos sedimentos, a estatistica deve ser usada para estudar as suas variações, numa anālise em conjunto, organizando e sinte tizando dados. No estudo sedimentolögico as seguintes medidas estatísticas são as mais usadas: diâmetro médio, mediana e percentil (medidas de posição), desvio padrão, quartis (medidas de dispersão), curtose e assimetria. A média indica a ordem de magnitude dos tamanhos da partícula, o desvio padrão empregado como medida de dispersão relaciona-se com o grau de seleção, os coeficientes de assimetria e curtose indicam a 
forma de distribuição sendo que esta ültima retrata a agudez dos picos de distribuição de frequência e a assimetria o afas tamento do diâmetro médio ou mediana.

Värios autores discorreram sobre estatistica em sedimentologia, entre eles KRUMBEIN (1936) que empregou a escala de WENTWORTH após transformar o tamanho do separato do solo em milimetro para a escala $\varnothing$. Em trabalho posterior (1938) esse autor mostrou que a conversão logaritmica para a escala $\emptyset$ gera curva de frequência normal.

Outro parâmetro de importância no estudo sedimentológico relaciona-se com o grau de arredondamento por per mitir explicar histörias de depósitos sedimentares. Estudo inicial comparativo entre arredondamento de grânulos minerais e seu transporte foi feito por sorby em 1879 (KRUMBEIN e PETTIJOHN, 1938), que classificou grânulos de areia em cinco classes de arredondamento. RUSSEL e TAYLOR (1937) desenvolveram tabelas de comparação de arredondamento de cinco graus e as distinções entre as classes são caracterizados por certos valores numericos de graus de arredondamento de WADEL (1932), e PETTIJOHN (1957) introduziu cinco classes de arredondamento: grânulo angular $(0,00-0,15)$; subangular $(0,15-0,25)$; subarredondado $(0,25-0,40)$; arredondado $(0,40-0,60)$ e bem arredondado $(0,60-1,00)$. 
9

3. LOCALIZAÇÃO DA AREA ESTUDADA

A ārea estudada situa-se no município de Corumbataí (SP), próximo a borda com o Planalto ocidental e está to talmente inserida na Depressão Periferica. Localiza-se aproximadamente às seguintes coordenadas geográficas: $22^{\circ} 16^{\prime} \mathrm{s}$ e $47^{\circ} 37^{\prime}$ W de Greenwich. (Eigura 1).

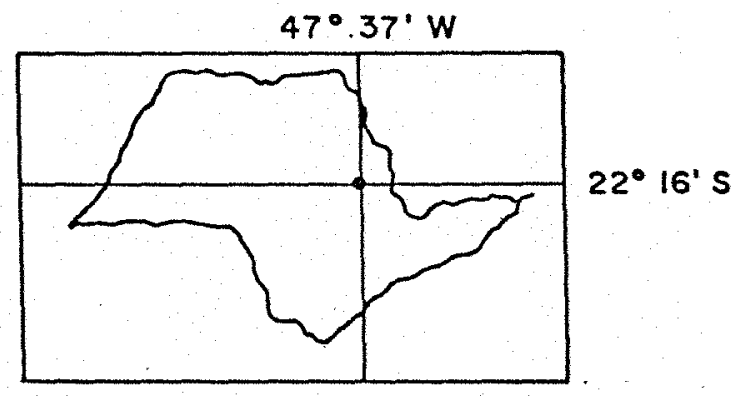

Figura 1. Localização da ārea estudadano Estado de São Paulo 


\section{MATERIAIS E METODOS}

4.1. Materiais

Foram estudadas duas encostas (A $e$ B), nas quais foram descritas e coletadas amostras de solo de quatro perfis na encosta $A(P 1, P 2, P 3$ e P4) e três perfis na encosta B (P5, P6 e P7). Os perfis estäo localizados ao sul de corumbataí, conforme estā assinalado na figura. 2. Os três perfis que ocu pam as posições mais elevadas na encosta A (PVls) tem como substrato o arenito da Formação Piramböia, enquanto que o perfil da parte mais baixa do relevo (PVp) está sobre o folhelho da Formação Corumbataí. Na encosta B os dois perfis das partes mais altas (PVIs) e o terceiro (PVp) relacionam-se respectivamente com os mesmos arenitos e folhelhos. (Figura 3 ).

o PVp selecionado apresenta gradiente textural muito elevado, com teores de argila no horizonte All e B2l de $5,8 \%$ e. $28,8 \%$, respectivamente (Perfil P4) e $9,5 \%$ e $27,3 \%$ (Perfil P7), respectivamente.

Como existem poucos trabalhos sobre o arenito 
da Formação Piramböia e sobre o folhelho da Formação Corumbataí, foram coletadas em ārca circunvizinha a ambas encostas se lecionadas, amostras desses materiais para caracteriza- $10 s$ sob - ponto de vista granulométrico, mineralögico da fração areia (pesados) e de morfoscopia dos grãos de quartzo, com o objetivo de se conhecer suas amplitudes de variaçöes e comparä-1as com as dos perfis de solos das encostas A e B.

o relevo da ärea estudada é ondulado, com decli ves que variam de 8 a $16 \%$, mantidos nas cotas de 600 a $640 \mathrm{~m}$. Em geral os topos das encostas são quase planos, com déclive inferior a $3 \%$ e têm pequena expressão de ārea. No final das en costas ocorre planície aluvional de pequena expressão geogräfi ca.

Segundo o mapa geológico do Estado de São Paulo (IPT, 1981) ocorrem na ärea estudada duas unidades litoestrati gräficas: Grupo Passa Dois representada pela Formação Corumbataí e Grupo São Bento representado pela Formação Pirambóia. As rochas pertencentes à Formação Corumbataí são constituídas por depósitos possivelmente marinhos incluindo argilitos, folhelhos e siltitos cinza arroxeados ou avermelhados. A rocha da Formação Pirambōia é constituida de depósitos fluviais incluin do os arenitos.

Na encosta A, os perfis P1, P2 e P3 (PVIs). estão relacionados com o arenito da Formação Pirambóia e o P4 (PVp) com o folhelho da Formação Corumbatal. Na encosta $B$ os 
perfis P5 e P6 (PVIs) relacionam-se com o arenito e o P7 (PVp) com ofolhetho (Figura 3 ).

Na região estudada são praticamente inexistentes locais com vegetação original e nos poucos locais onde persistem, o cerrado constitui a vegetação primäria remanescente. 


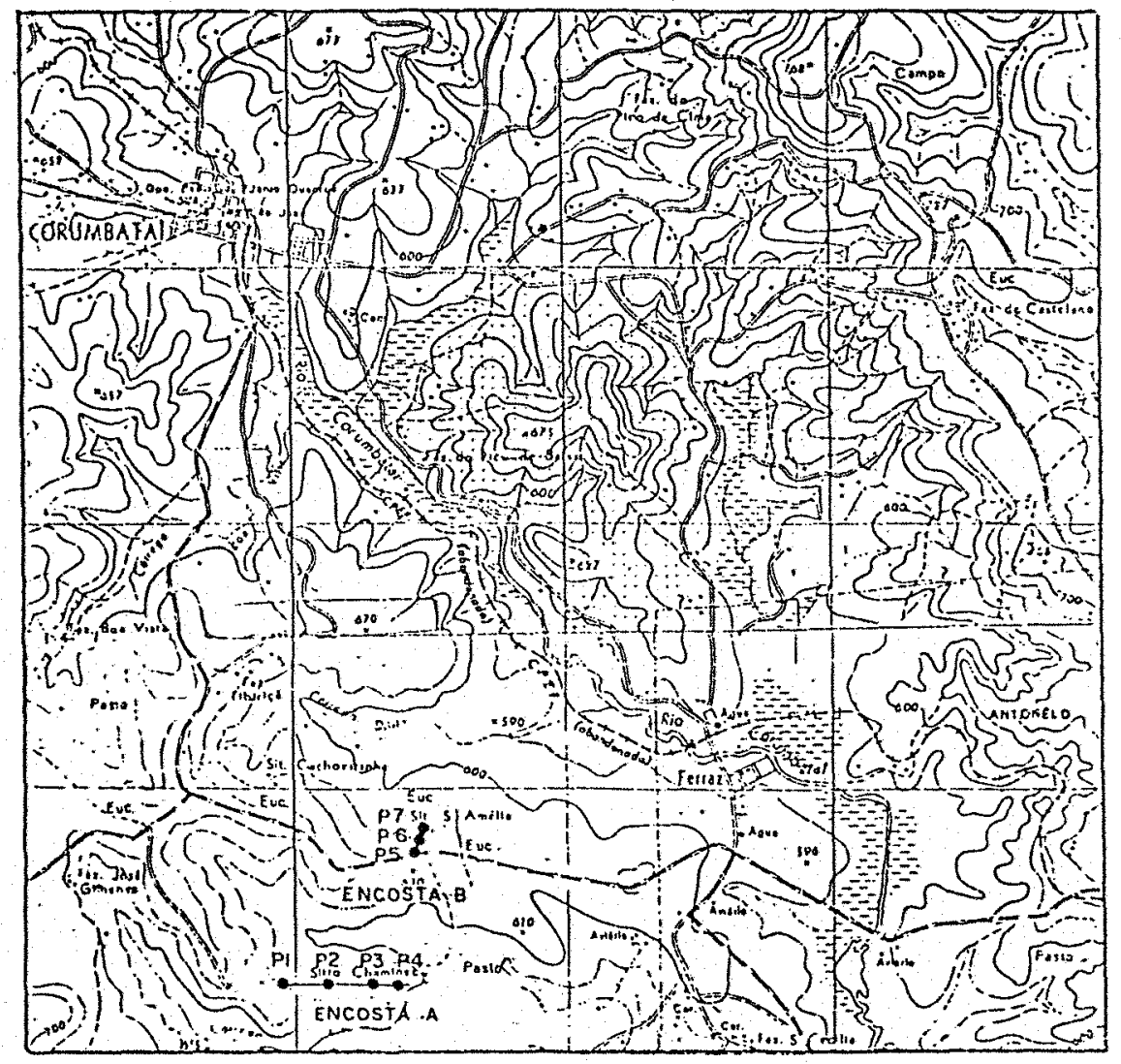

Figura 2. Localização das encostas A e B nas Folhas Topogräfi cas de Corumbataí e Rio Claro, SP.

Escala 1:50.000. 


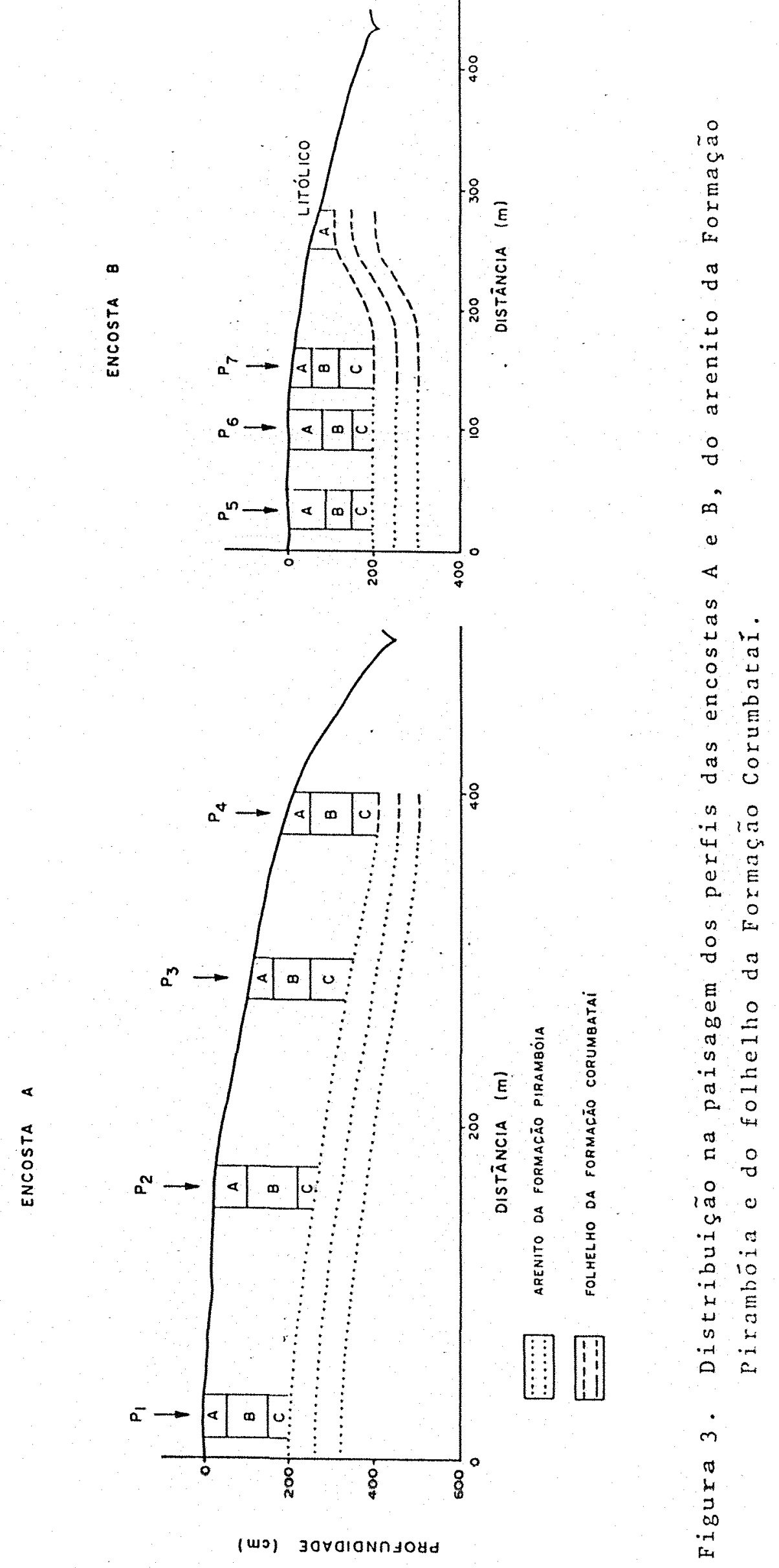


A classificação climātica de toda a ärea estuda da pelo sistema de köppen è do tipo CWa ou seja, clima mesotér mico de inverno seco. Pelo cálculo do balanço hídrico, efetuado pelo método de Thorthwaite \& Mather (para $125 \mathrm{~mm}$ ) de retenção de água no solo; a deficiência hídrica anual è de $49 \mathrm{~mm}$, concentrada a partir de abril até o final de setembro. o perío do de māxima precipitação pluvial compreende os meses de outubro a março, com excedente máximo de $356 \mathrm{~mm}$ (Figura 4). A Tabe 1 a 1 apresenta dados mensais de precipitação pluvial e temperatura do município de Rio Claro ( $S P$ ).

Tabela 1. Precipitação pluvial mensal registrada no município de Rio Claro (SP) no período de 1941-1970, e temperatura estimada através de regressão (PINTo et alii 1972 )

Mes

Precipitação

Temperatura

\begin{tabular}{lcc} 
& $\mathrm{mm}$ & oc \\
\hline Janeiro & 226 & 23,0 \\
Fevereiro & 205 & 23,0 \\
Março & 149 & 22,5 \\
Abril & 44 & 20,8 \\
Maio & 44 & 18,2
\end{tabular}


Tabela 1. (cont.)

\begin{tabular}{lcc} 
Mes & Precipitação & Temperatura \\
\hline & mm & ${ }^{\circ} \mathrm{C}$ \\
Junho & 29 & 16,8 \\
Julho & 20 & 16,6 \\
Agosto & 25 & 18,0 \\
Setembro & 53 & 19,8 \\
Outubro & 126 & 21,0 \\
Novembro & 132 & 22,0 \\
Dezembro & 199 & 22,5 \\
\hline
\end{tabular}

Fonte: Seção de Climatologia Agrícola do Instituto Agronômico. 


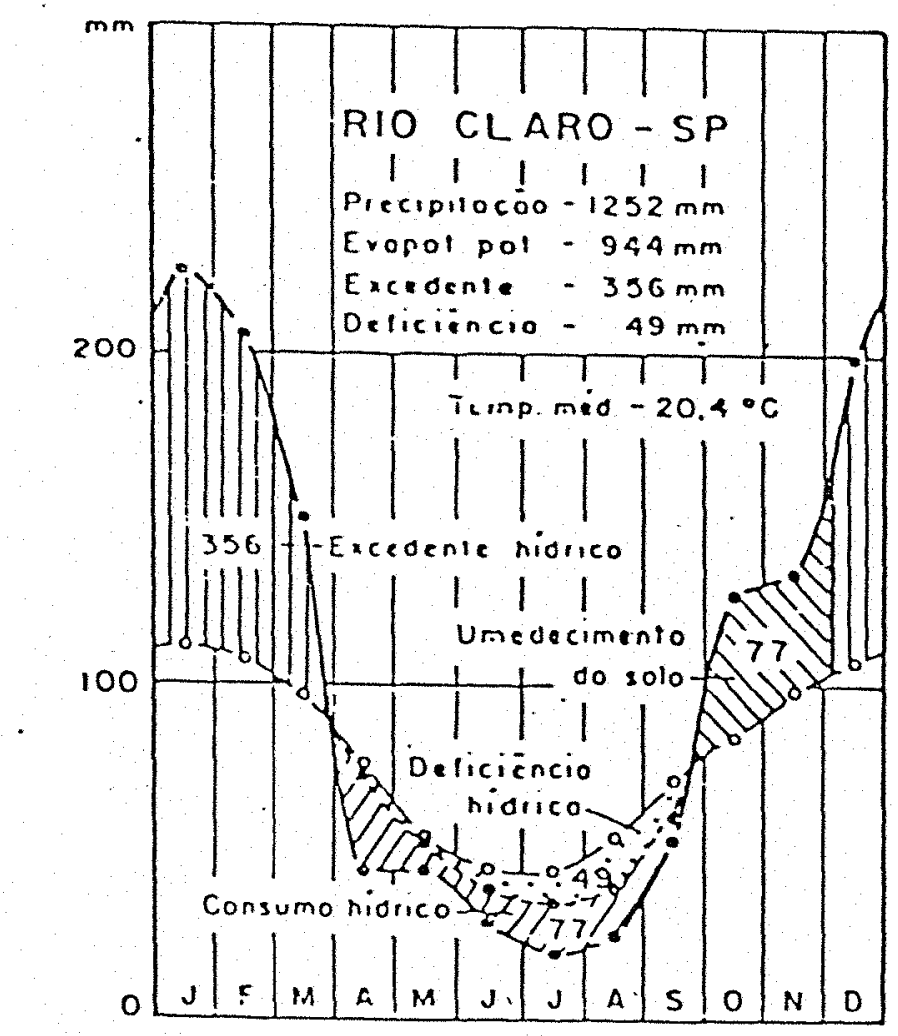

Figura 4. Balanço hídrico pelo método Thornthwaite \& Mather (1955) para a localidade de Rio Claro (SP), armazenamento de $125 \mathrm{~mm}$ de āgua no solo. Fonte: Seção de Climatologia do Instituto Agronômico de Campinas ( SP). 
4.2. Mētodos

As amostras foram secas ao ar, destorroadas e passadas em peneiras de $2 \mathrm{~mm}$ de abertura e a fração menor que esse valor constitui a terra fina seca ao ar (TFSA).

4.2.1. Métodos de Laboratório

4.2.1.1. Anālise química

Foram feitas as seguintes determinações:

- $\underline{\mathrm{pH}}$ èm ägua e em solução de cloreto de potássio 1N: determina ção potenciométrica após três horas de repouso; relação solo1iquido $1: 2,5$.

- Carbono orgânico (C): oxidação da matéria orgânica com solução $1 \mathrm{~N}$ de dicromato de potássio em meio ácido e titulação do excesso de dicromato com solução de sulfato amoniacal $0,05 \mathrm{~N}$ e uso da difenilamina como indicador (VETTORI, 1969).

- Bases trocāveis: extração por agitação de $5 \mathrm{~g}$ de T.F.S.A. com $50 \mathrm{ml}$ de $\mathrm{NH}_{4} \mathrm{OAC} 1 \mathrm{~N} \cdot \mathrm{pH} 7,0$. O cälcio e o magnésio foram determinados no extrato por espectrofotometria de absorção atômi ca, utilizando-se solução de óxido de 1 antânio a $0,2 \%$ para eli minar a interferência do alumínio e fósforo (SLAVIN, 1968). o potásio foi determinado por fotometria de chama (CATANI e PAI VA NETO, 1949). 
- Acidez titulável $\left(H^{+}+A 1^{3+}\right)$ : extração por agitação de $5 g$ de T.F.S.A. com 100ml de acetato de cálcio $1 \mathrm{~N}$ pH 7,0 e titulação com $\mathrm{NaOH} 0,1 \mathrm{~N}$, us ando fenolftaleina como indicador.

- Alumínio trocāvel $\left(\mathrm{Al}^{3+}\right)$ : extração por agitação de $5 \mathrm{~g}$ de $\mathrm{T}$. F.S.A. com $100 \mathrm{ml}$ de cloreto de potässio $1 \mathrm{Netitulaçãocom} \mathrm{NaOH}$ $0,1 \mathrm{~N}$ usando fenolftaleina como indicador.

- Ferro livre: extração com citrato-bicarbonato-ditionito(CBD) segundo JACKSON (1969).

- Ferro oxalato: extração com solução ācida de oxalato de amônio e determinação por absorção atômica (SCHWERTMANN, 1964).

- Ferro tota 1: digestão com $\mathrm{H}_{2} \mathrm{SO}_{4} \mathrm{~d}=1,47$ e determinação colori métrica em aliquotas do filtrado usando 1,10 o-fenantrolina. (RAIJ e VALADARES, 1974).

- Potássio total: o potássio total da fração argila $(<0,002 \mathrm{~mm})$ foi extraído por digestão a quente com ācido sulfúrico 18N.Uti lizou-se $\lg$ de argila e na determinação do teor de potāsio utilizou-se ofotômetro de chama. A porcentagem de ilita (mica) presente na amostra foi determinada baseando-se em JACKSON $(1956)$, isto $\bar{e}$, assumindo-se que $1 \%$ de $\mathrm{K}_{2} \mathrm{O}$ corresponde a $10 \%$ de ilita. 
4.2.1.2. Anālise Granulométrica

A composição granulométrica foi determinada pe1o método da pipeta, utilizando-se o hexametafosfato e hidróxi do de sódio, segundo GROHMANN \& RAIJ (1973). A escala textural empregada è a de ATTERBERG (Tabela 2).

Tabela 2. Escala granulómétrica segundo Atterberg

$\mathrm{mm}$

$2,0 \therefore-0,2$

$0,2-0,02$

$0,02-0,002$

$<\quad 0,002$
Classificaçāo

areia grossa

areia fina

silte

argila

Como na classificação de Atterberg é pequeno o nümero de subdivisões das classes de particulas unitárias, uti lizou-se também aquela preconizada por Wentworth $\therefore$ que adota maior nümero de sub frações, especialmente da fração areia, on de foram utilizadas as seguintes peneiras: 2,00; 1,410; 1,00; 0,$707 ; 0,500 ; 0,354 ; 0,250 ; 0,177 ; 0,125 ; 0,088$ e $0,062 \mathrm{~mm}$. A fração argila foi determinada pelo método da pipeta, enquanto que a fração silte por diferença. Utilizou-se o processo convencional de pipetagem para as particulas menores que $0,062 \mathrm{~mm}$, e peneiramento para as partículas maiores que essa dimensão. Foram empregados intervalos de $1 / 2 \emptyset$ nas classes de peneiramento e $1 \varnothing$ nas classes dimensionadas por pipetagens, que são os 
intervalos da escala textural de Wentworth (1922) (Tabela 3).

Tabela 3. Escala granulométrica segundo Wentworth

Tamanho

Classificação

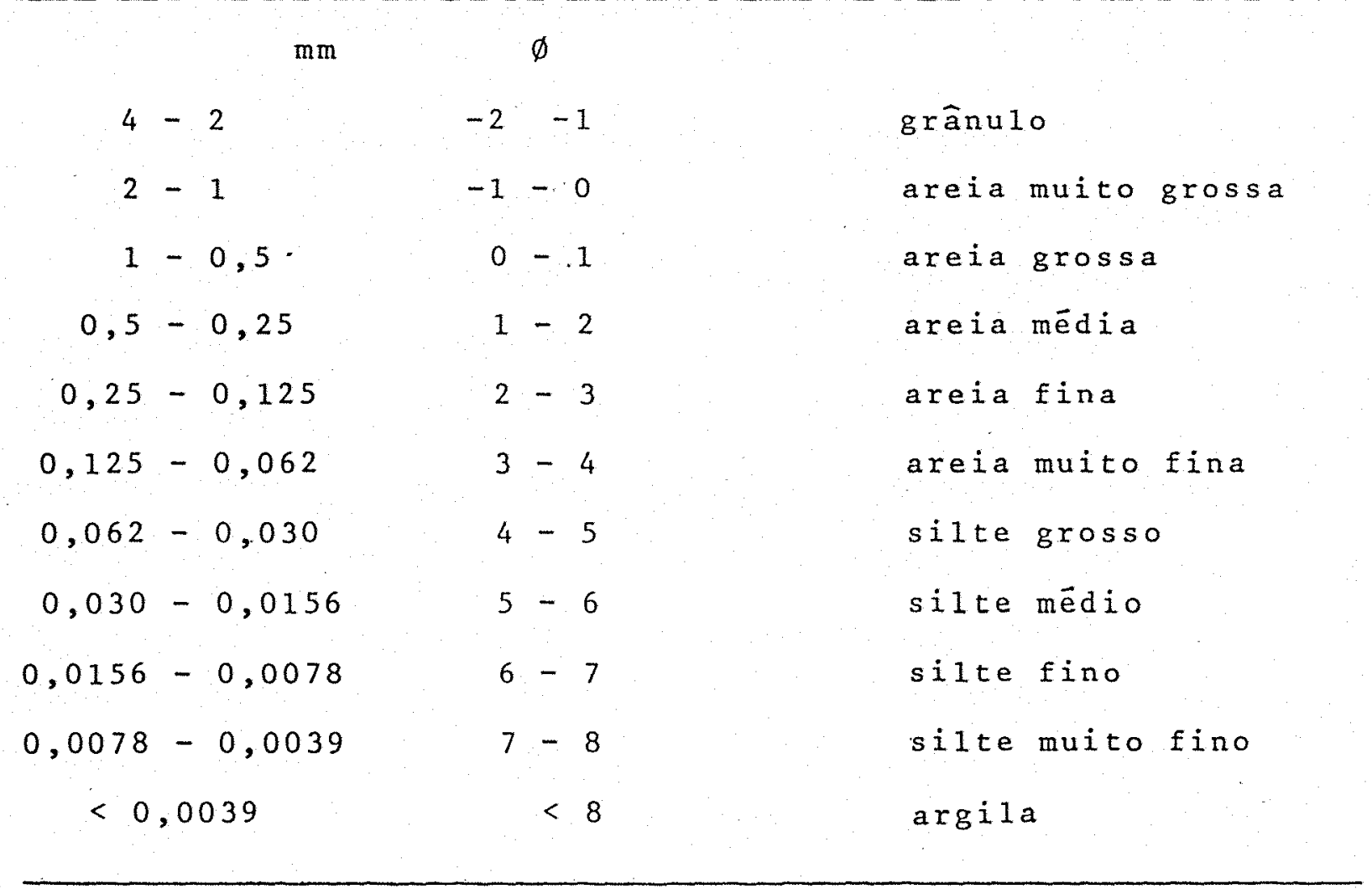

De cada amostra de solo foram separados $10 \mathrm{~g}$ de TFSA para ser utilizados na anālise granulométrica pelo método da pipeta. Essas amostras foram colocadas em frascos de ErIenmeyer com ägua destilada e posteriormente acondicionadosem ag $\underline{i}$ tador rotativo com alta rotação e agitadas por 15 minutos. Em seguida, a argila e o silte foram eliminados através da peneira de malha $0,053 \mathrm{~mm}$, sob jato de àgua. 
Esse procedimento foi repetido atè que todo o sobrenadante fosse esgotado, restando apenas a fraça total a qual foi submetida a tratamentos para a eliminação da matéria orgânica e oxidos de ferro livre.

Para a obtenção da fração areia do folhelho, ut lizou-se $100 \mathrm{~g}$ de folhelho, deixando esse material em contato com àcido clorídrico $1 \mathrm{~N}$ diluído em ägua na proporção 1:1. A ca da três dias foi feita agitação mecânica combastão de vidro para facilitar a desagregação do folhelho. obtida a fração de tamanho areia, esta foi misturada com ägua destilada em becker de $50 \mathrm{ml}$ e colocado no ultrassom por aproximadamente cinco minu tos. Em seguida esse material foi peneirado em peneira de maIha $0,053 \mathrm{~mm}$ e levado a lupa de aumento para verificar se não mais apresentava agregados, at $\vec{e}$ constituir-se de apenas areia quartzosa.

\subsubsection{Anāilse estatistica}

Foram utilizados os parâmetros estatísticos de FOLK \& WARD (1957, in SUGUIO, 1973) para descrever os sedimentos em termos de suas propriedades ligadas a distribuição granulométrica, indicando o diâmetro médio, o desyio padrão, grau de assimetria e a curtose. 
4.2.1.4. Anälise de morfoscopia

Na anālise de morfoscopia dos gräos de quartzo utilizou-se a técnica de comparação visual, conforme descrição in suguro (1973). Foram feitas contagens de 100 grãos da areia muito fina (fração de $0,125-0,062 \mathrm{~mm}$ ), utilizando-se a lupa estereoscópica.

4.2.1.5. Estudo dos minerais pesados

Nos sedimentos a separação dos minerais pesados foi feita com auxílio de bromofórmio, segundo a tëcnica descri ta por KRUMBEIN PETTIJOHN (1938). Os minerais foram montados em lâminas de vidro usando-se como meio de montagem o balsamo do Canadá e em seguida foram feitas identificações e contagens de 100 grãos de minerais transparentes da fração areia muito fina $(0,125$ a $0,062 \mathrm{~mm})$, correndo-se sistematicamente a lâmina sobre a platina do microscōpio petrográfico com o auxílio do "charriot".

4.2.1.6. Anā1ise micromorfolögica

Inicialmente as amostras secas ao ar foram inpregnadas a vācuo, utilizando-se como meio resina poliester, na qual foi adicionada estireno para redução da viscosidade e 
peróxido de metil-etil-cetona como agente catalizador. As amos tras colocadas em dessecadores adaptados para impregnação foram mantidas sob vācuo por período de tempo necessário à renoção do ar. Em seguida foram deixadas a temperatura ambiente por vários dias para endurecimento do material. Procedeu-se o corte, polimento por via úmida com pó de carborundumemontagez em lâminas de vidro com bálsamo do canadá. o polimento final foi feito com o referido pó, sucessivamente mais fina até a ob tenção de secçó̀es delgadas com cerca de 30 micra de espessura.

4.2.1.7. Anālise mineralögica da fração argila

Realizada com difração de raios $X$ em amostzas previamente tratadas para eliminação da matēria orgānica e $\overline{0}: \underline{\text { I }}$ dos deferro, saturadas com magnésio, glicolação e temperatu ras variadas após a saturação com potāsio. 
4.2.2. Método de trabalho de campo

o trabalho de campo consistiu no percurso pela região do município de Corumbataí (SP) visando selecionar as encostas para posterior descricão dos perfis de solos. Esse trabalho foi facilitado pois durante o levantamento pedológico semidetalhado da quadrícula de são Carlos (PRADo et alii, 1981) verificou-se a ocorrência de solos derivados do folhe1ho da Formação Corumbataí que possuem o carāter abrūptico,ou seja, apresentam brusca mudança textural com exagerado aumento de argila (equivalente ao dobro ou mais), num pequeno intervalo vertical na zona limitrofe do horizonte $A$ para o $B$ (ate $7,5 \mathrm{~cm})$.

Os perfis de solos foram examinados e amostra dos em trincheiras e a descrição morfológica obedeceu as normas estabelecidas no Manual para Descrição de solo no Campo. (INSTITUTO AGRONÔMICO, 1969 ). 
5. RESULTADOS E DISCUSSAOO

5.1. Encosta A

5.1.1. Anālises químicas

a) $\mathrm{pH}$ em àgua

Observando os dados de pH em ägua, nota-se que os perfis P1, P2 e P3 no horizonte A apresentam valores com menor amplitude de variação $(4,9$ a 5,4$)$ do que o perfil p4 $(5,5$ a 5,8$)$ (Tabelas 4 a 7 ). Em todos os perfis há aumento da acidez à medida que aumenta a profundidade e os valores de $p H$ em cloreto de potássio são inferiores aos valores de $\mathrm{pH}$ em āgua, portanto o $\Delta \mathrm{pH}$ é negativo. Segundo MEKARU e UEHARA(1972) e RAIJ e PEECH (1972), pH negativo indica predominânciade car ga líquida negativa no solo. 
b) Carbono

os valores de carbono são mais elevados no horizonte A do que em profundidade em todos os perfis estudados, em razão da maior adição de matéria orgânica pela decomposição das raízes. (Tabelas 4 a 7 ).

c) Soma e saturação em bases

Os valores de soma de bases (S) nos horiozntes superficiais variam de 0,5 a 3,6 meq/100g diminuindo em profundidade nos perfis P1 e P4 e aumentando no P2 e P3.

os valores de saturação em bases são mais elevados no horizonte A dos perfis P1 ao P4 (22 a $55 \%$ ) diminuindo significativamente em profundidade (1 a 15\%). Os valores mais elevados de saturação em bases que ocorrem nos horizontes superficiais provavelmente são devidos a adubação e/ou ao eféito da reciclagem de bases. (Tabelas 4 a 7 ).

d) Capacidade de troca de cātions e saturação em alumínio

Os perfis P2 e P3, ao conträrio do P1 e. P4, apresentam capacidade de troca de cätions com valores superio res a 24 e.mg/100g de argila após correção do carbono, portan to são solos com argila de atividade alta. Todosos perfis des sa encosta possuem o caräter älico visto que a saturação em alumínio supera $50 \%$. (Tabelas 4 a 7 ). 
DEMATTE (1970) estudando solos classificados co mo Podzōlico Vermelho-Amarelo variação Piracicaba (COMISSÃo DE SOLOS, 1960) e que corresponde aos perfil p4 e P7 do preserte trabalho, verificou que esse solo pode ter diferentes valores de saturação em bases.

\subsubsection{Anälise granulomëtrica}

A distribuição granulométrica do perfil Pl apon ta teores praticamente nulos das areias grossa e muito grossa ao longo do perfil, diminuição em profundidade das areias média e fina e aumento da areia múito fina nessa mesma direção. As areias fina e muito fina perfazem valores compreendidos entre 82 a $97 \%$ : da fração areia total a longo do perfil. o teor de argila aumenta gradualmente em profundidade assumindo valor de $8,2 \%$ no horizonte A1I e $20 \%$ no horizonte B2I (Tabela 8 ).

os dados granulométricos do perfil p2 mostram que com excessão dos horizontes AII e Al2. onde dominam as areias média e muito fina $(66 \%$ da areia total), nos demais horizontes hà predominância das areias fina e muito fina, cuja so ma atinge valores que variam de 74 a $79 \%$ da areia total.os teo res de argila são 1,6 e $25,2 \%$ nos horizontes All e B2l, respec tivamente (Tabela 9). 
A anālise granulométrica do perfil P3 apresenta valores de areia que aumentam, e diminuem em profundidade, e em quase todos os horizontes predominam as areias fina e muito fina ( 53 a $76 \%$ da areia total). Os valores de argila sãode 6,7 e $30,9 \%$ nos horizontes $A 11$ e B21, respectivamente (Tabela 10).

Os dados granulométricos do perfil P 4 indicam que a areia total varia de 68 a $78 \%$ no horizonte A, 46 a $56 \%$ no horizonte B2 e 20 a $33 \%$ no horizonte C. Em relação a areia total, as areias fina e muito fina contribuem com valores que va riam de 74 a $79 \%$, no horizonte $A, 73$ a $76 \%$ no horizonte B 2 e 70 a $73 \%$ no horizonte C. (Tabe1a 11).

Os dados dos perfis PI, P2, P3 e P4 indicam que hā grande variação na composição granulométrica em profundidade, principalmente nos perfis P2, P3 e P4 que apresentam o carāter abrūptico.

5.1.3. Anälise estatistica

Os perfis desta encosta ( 1 ao $P 4)$ apresentam, respectivamente, valores de diâmetro médio da fração areia no horizonte $A 1$ de $0,15,0,13,0,16$ e $0,15 \mathrm{~mm}$, no horizonte B21 de $0,14,0,15,0,17$ e $0,16 \mathrm{~mm}$ e no horizonte $\mathrm{cl}$ de $0,13,0,15,0,22$ e $0,17 \mathrm{~mm}$. o desvio padrão apresenta do P1 ao P4 nos horizontes A, B e C os valores respectivamente, de $0,724,0,882,0,981$ e 
$0,835,0,728,0,958,0,943$ e 1,033, e $0,708,0,896,1,166$ e 1,127. De acordo com tralhahos de TRASK (KRUMBEIN e PETTIJOHN, 1938) sobre seleção de sedimentos os valores do desvio padrão no horizonte Al são: moderadamente selecionados (P1 ao P4). No horizonte B2 moderadamente selecionados (PI e P2), pobremente selecionados (P3) e moderadamente selecionados (P4). No horizonte Cl tem-se sedimentos moderadamente selecionados (P1 P2) e pobremente selecionados (P3 e P4). o grau de assimetria é ne gativo em todos os quatro perfis da encosta A, significando que a cauda da distribuição da fração areia se concentra no Ia do das areias mais grosseiras. A curtose apresenta no horizonte Al valor classificado como mesocūrtica (PI), muito platicūr tica (P2), platicürtica (P3) e mesocürtica (P4). No horizonte B21 os valores enquadram-se como mesocürtica (P1) e platicūrti ca (P2, P3 e P4) e no horizonte C1 como mesocürtica (P1 e P2), muito platicūrtica (P3) e platicürtica (P4). (Tabelas 12 a 15 ). A figura 5 apresenta a distribuição dos teores de argila e dos valores de diâmetro médio da fração areia ao longo do perfil (P1 ao P4). Observa-se nessa figura que, especialmente no PVP (Perfil 4), hä acentuado acrēscimo de argila em profundidade, e que ovalor da mediana da fração areia (diâmetro médio) è uniforme entre os horizontes $A$ e B, diminuindo no horizonte C. 

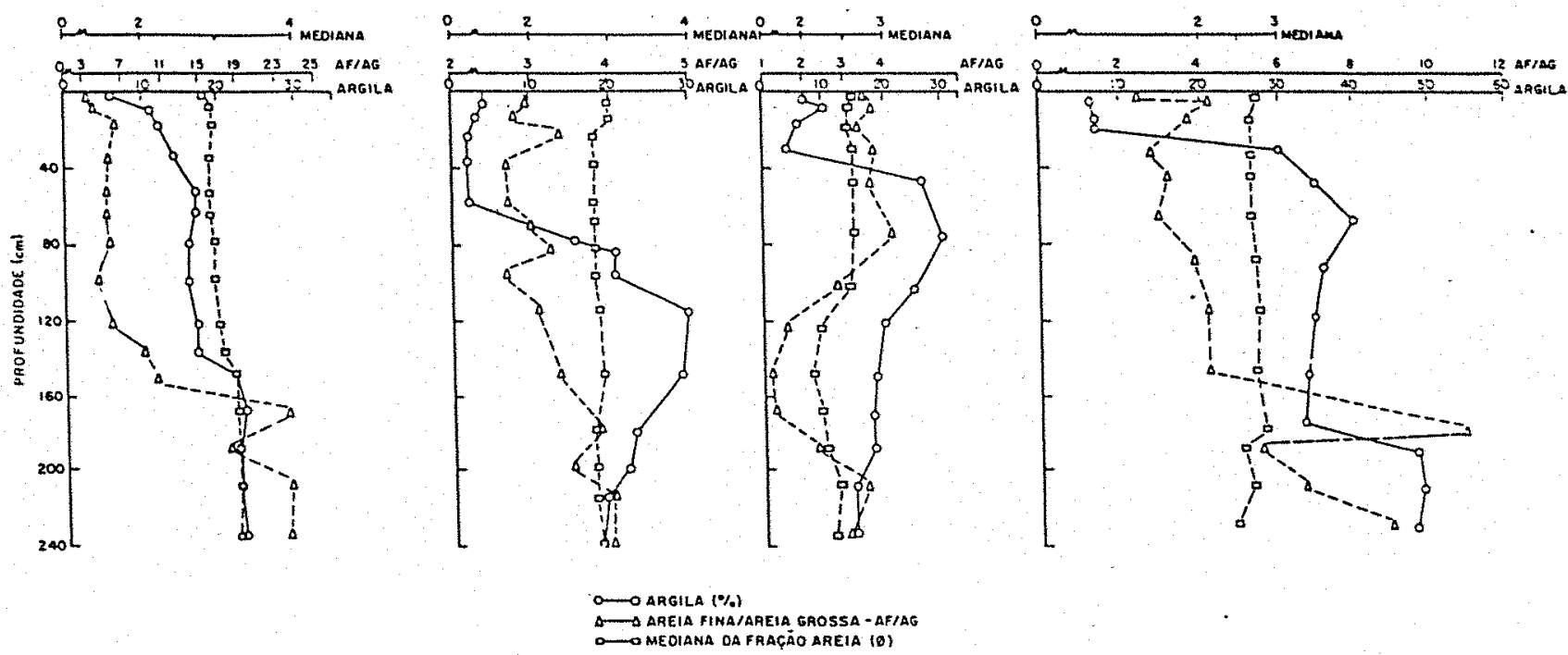

Figura 5. Distribuição em profundidade de argila (\%) da relação areia fina/areia grossa e da mediana da fração areia ( () dos perfis P1 ao P4 (Encosta A). 


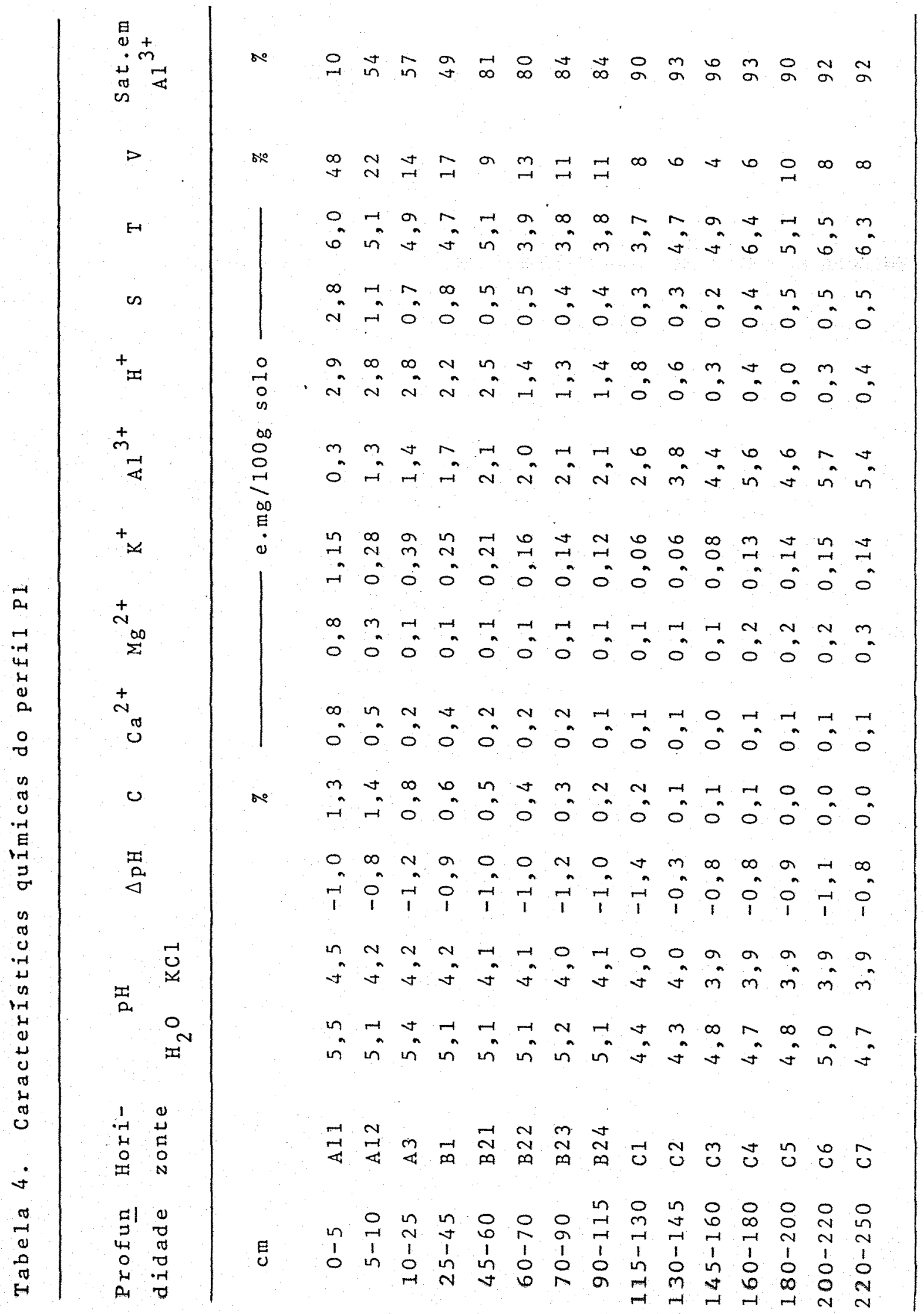




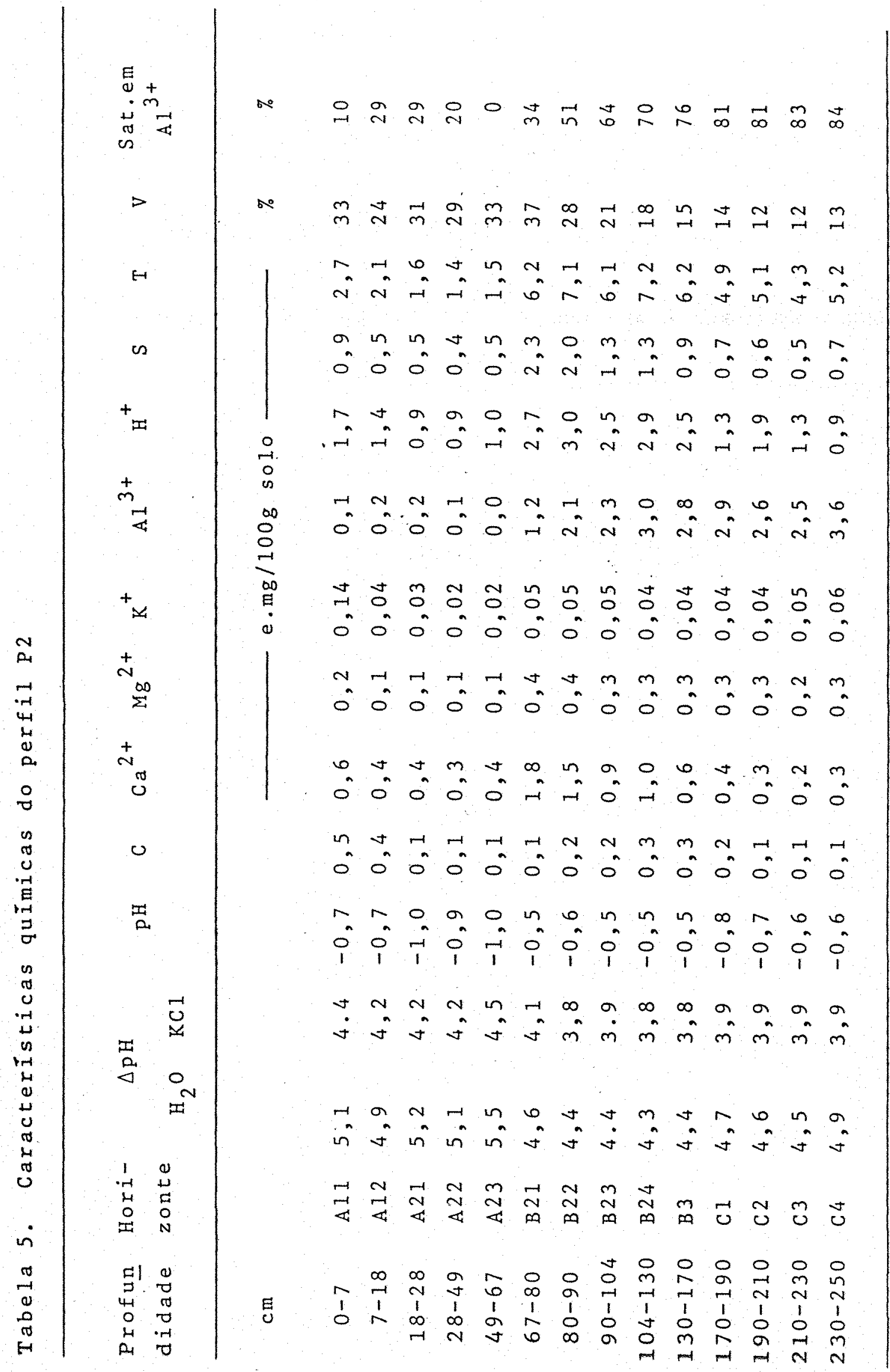




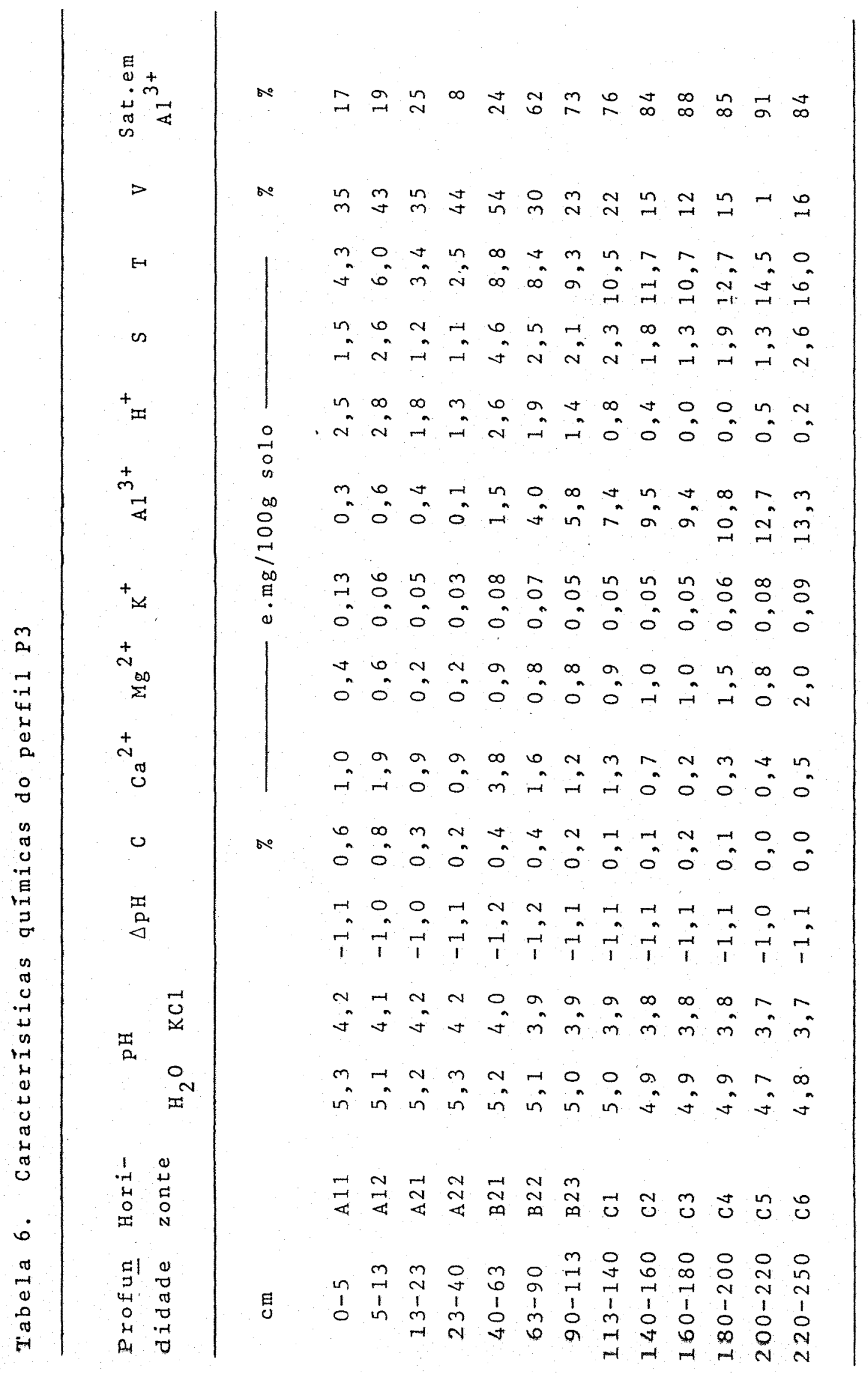




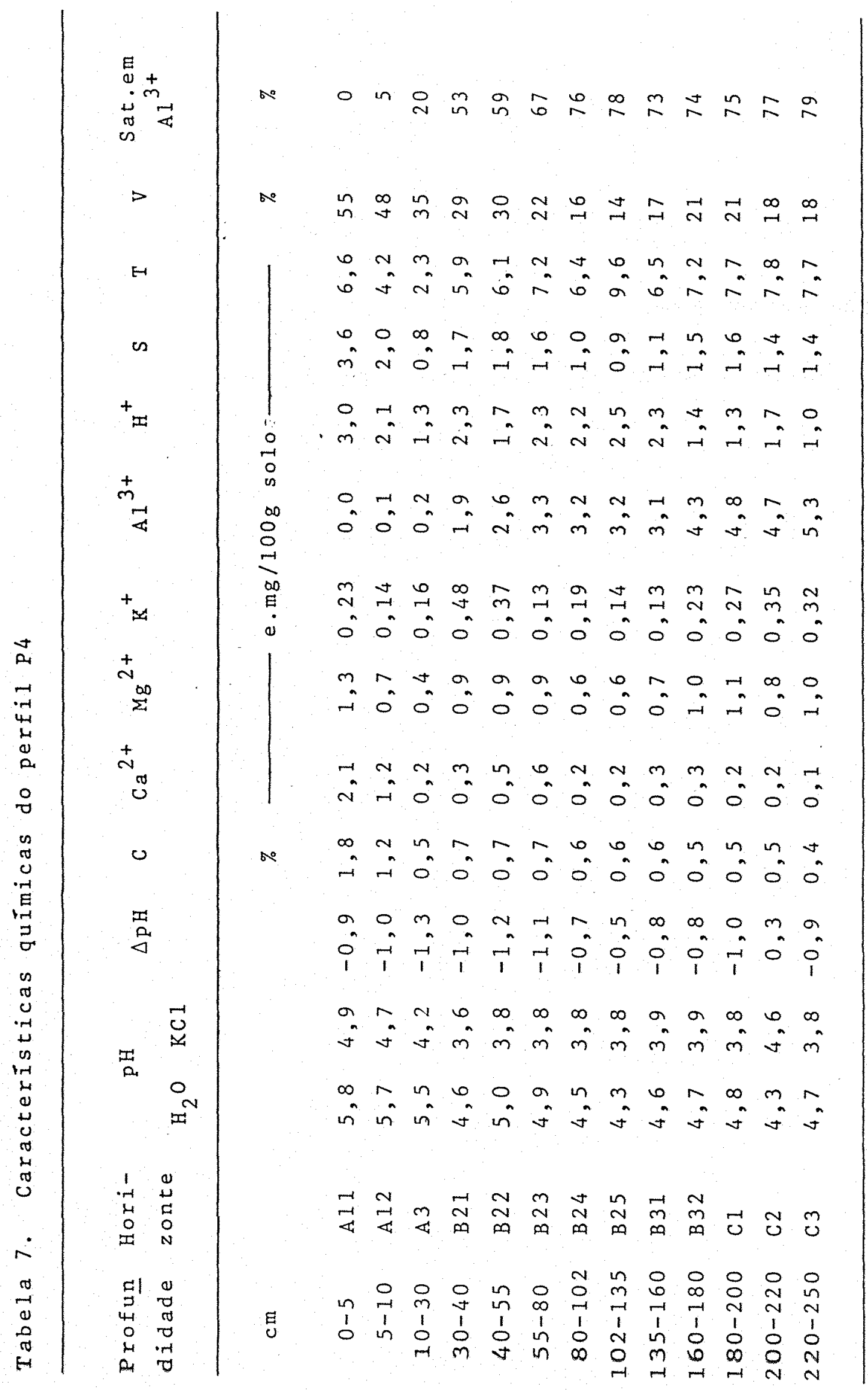




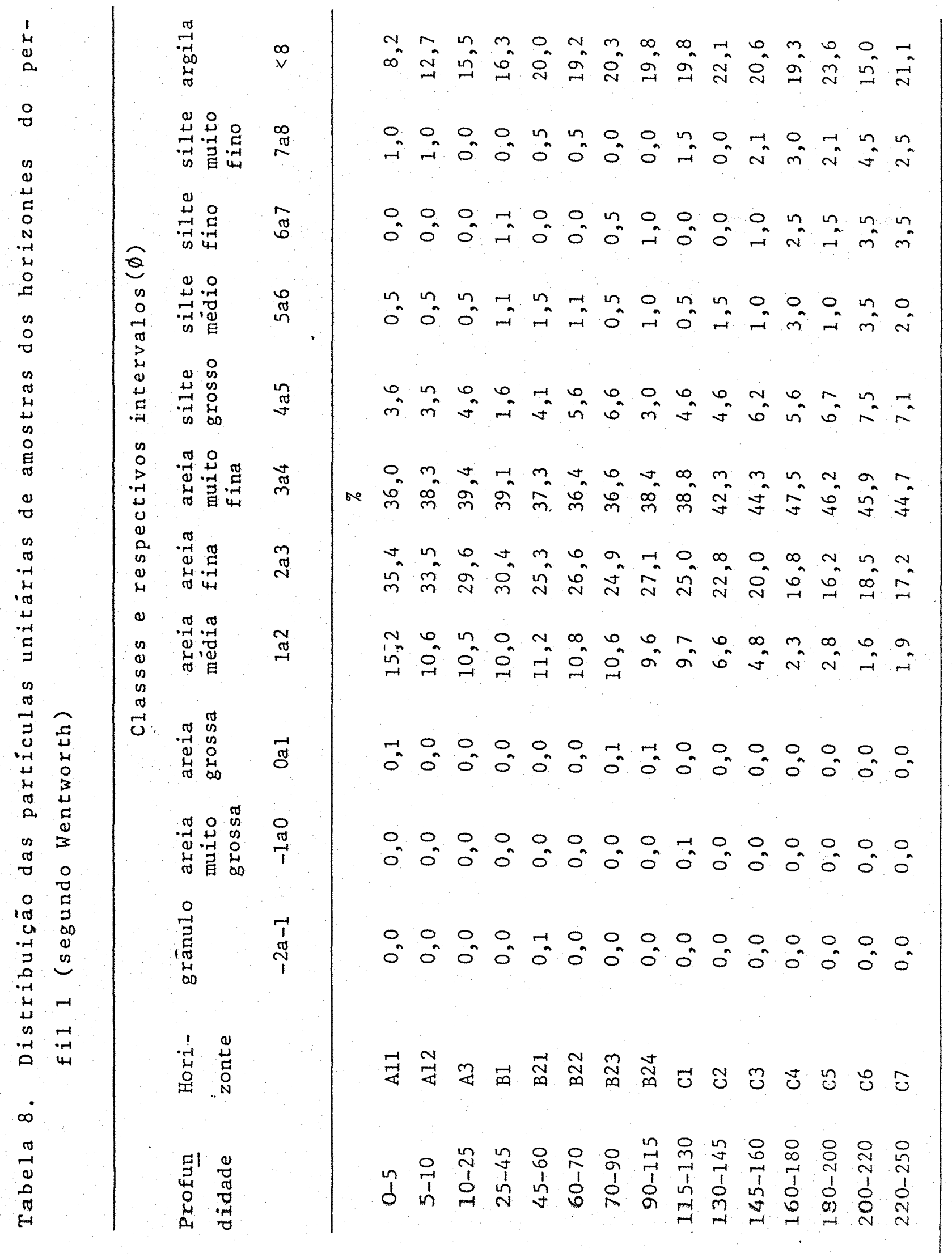




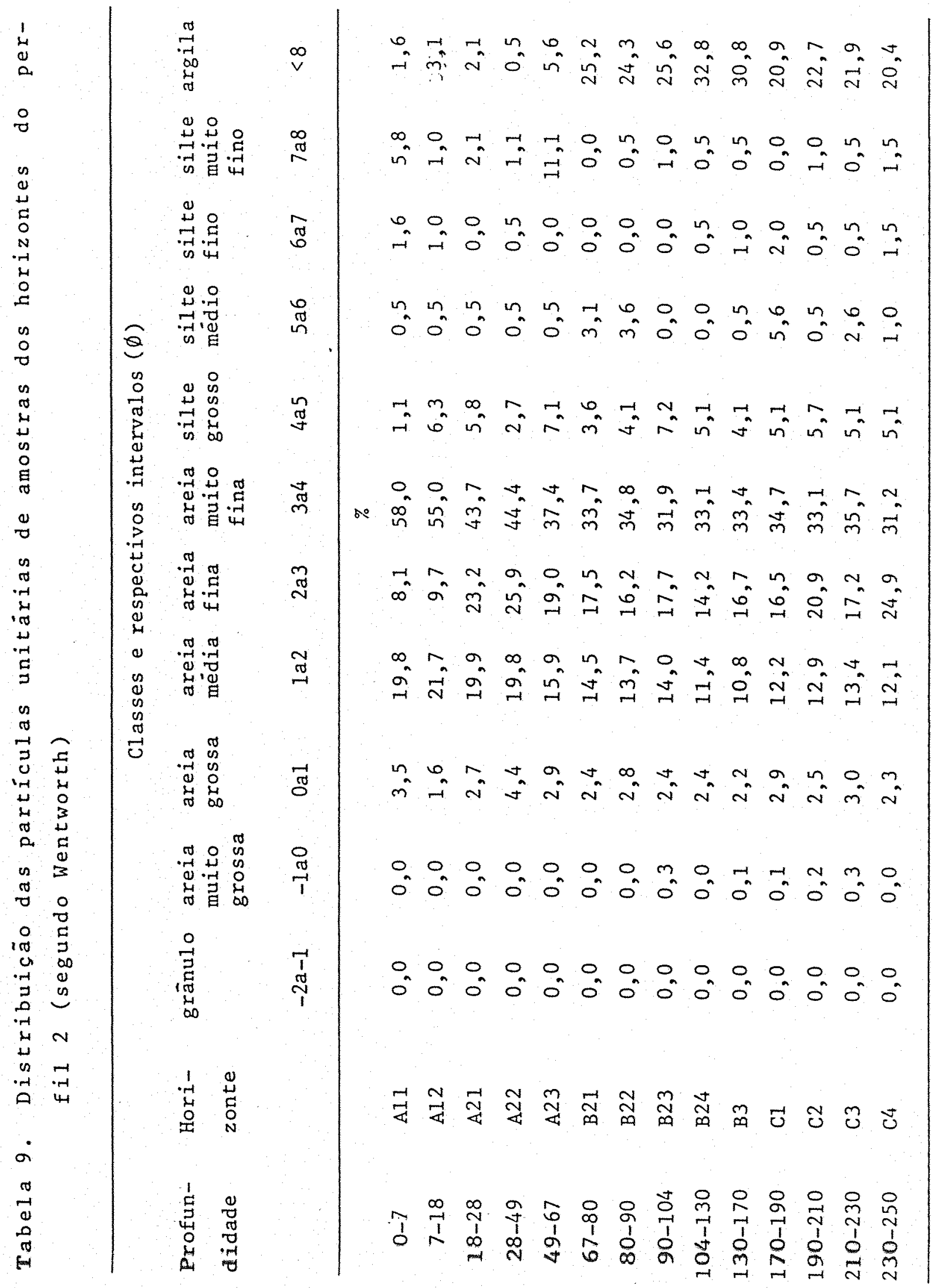




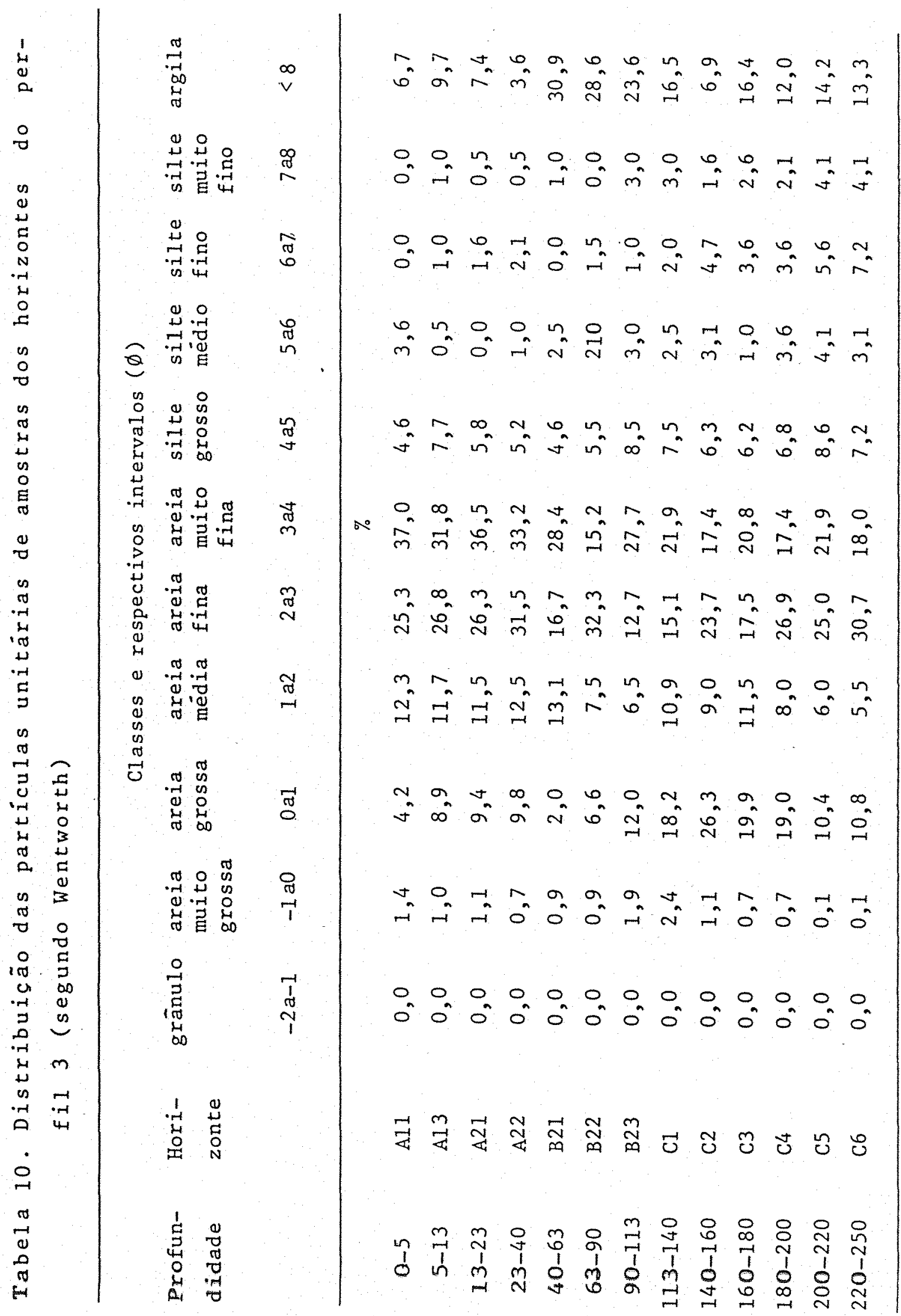




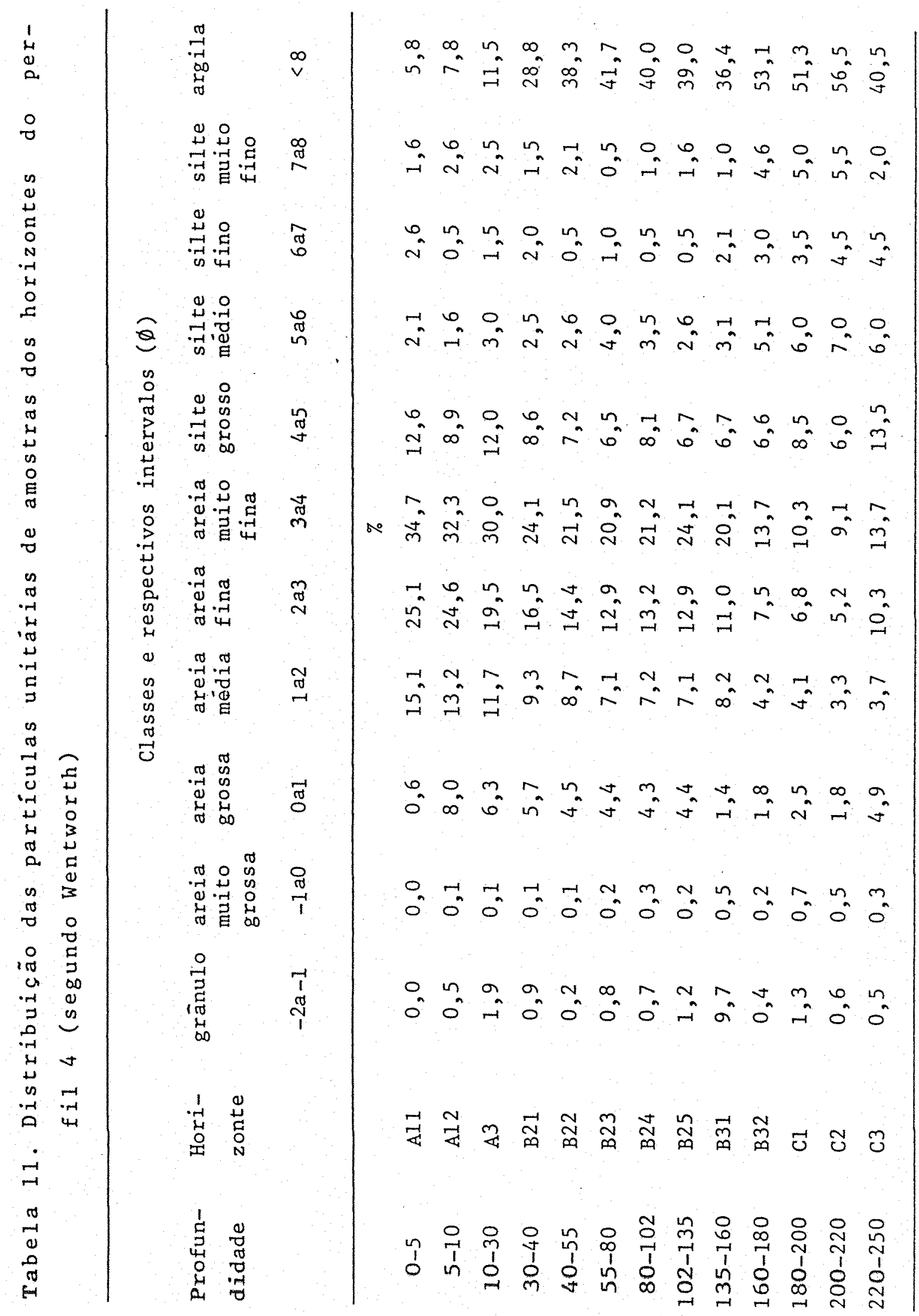


Relação areia fina/areia grossa

A relação areia fina/areia grossa tem sido frequentemente utiizada para se detectar indicios de descontinu王 dade litolögica (BARSHAD, 1964). Os valores dessa relação variam de 2,5 a 4,2 no PVp (perfil P4), sugerindo a ocorrêrcia de estratos coluvionais que foram sucessivamente depositados entre os horizontes A11 e $112, A 12$ e A3, A3 e B21 e B23 e B24. (Tabe 1 a 16).

A distribuição dos valores da relação areia fina/areia grossa (AF/AG) è apresentada na figura . Esses dados referem-se aos perfis da encosta A, que foi a encosta sele cionada para esse estudo. Todos os perfis apresentam variações dessa relação ao longo do perfil, especialmente os perfis PI (PVIs) e o P4 (PVp). Para o perfil PI foi verificado na profun didade de $160 \mathrm{~cm}$ o valor mäximo da relação AF/AG. Esse valor, provavelmente, $\vec{e}$ devido as diferentes estratificações prōprias do arenito da Formação Piramböia. Para o perfil P4 identificou-se na profundidade de $200 \mathrm{~cm}$ o maior valor da relação AF/AG. 


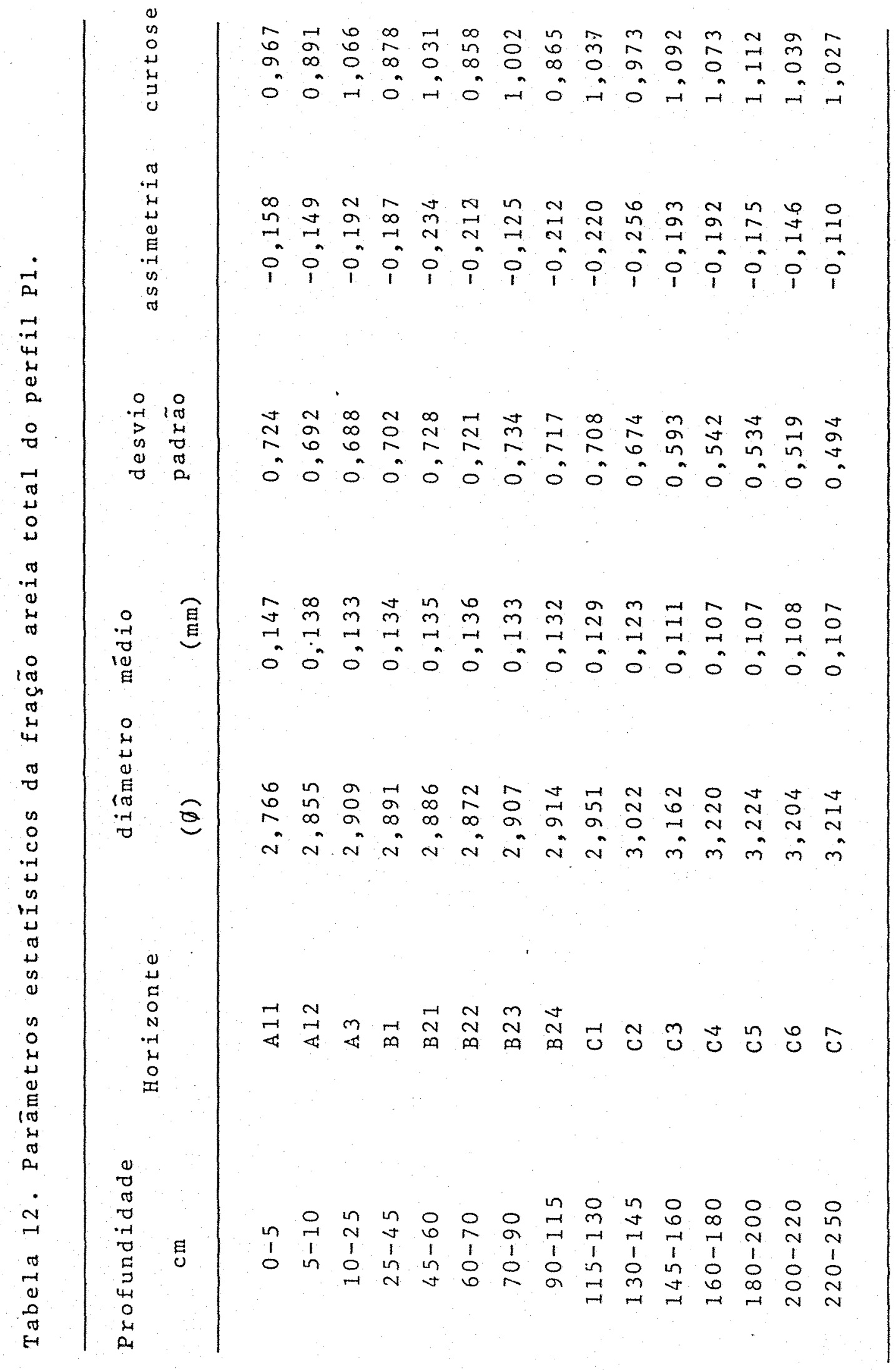




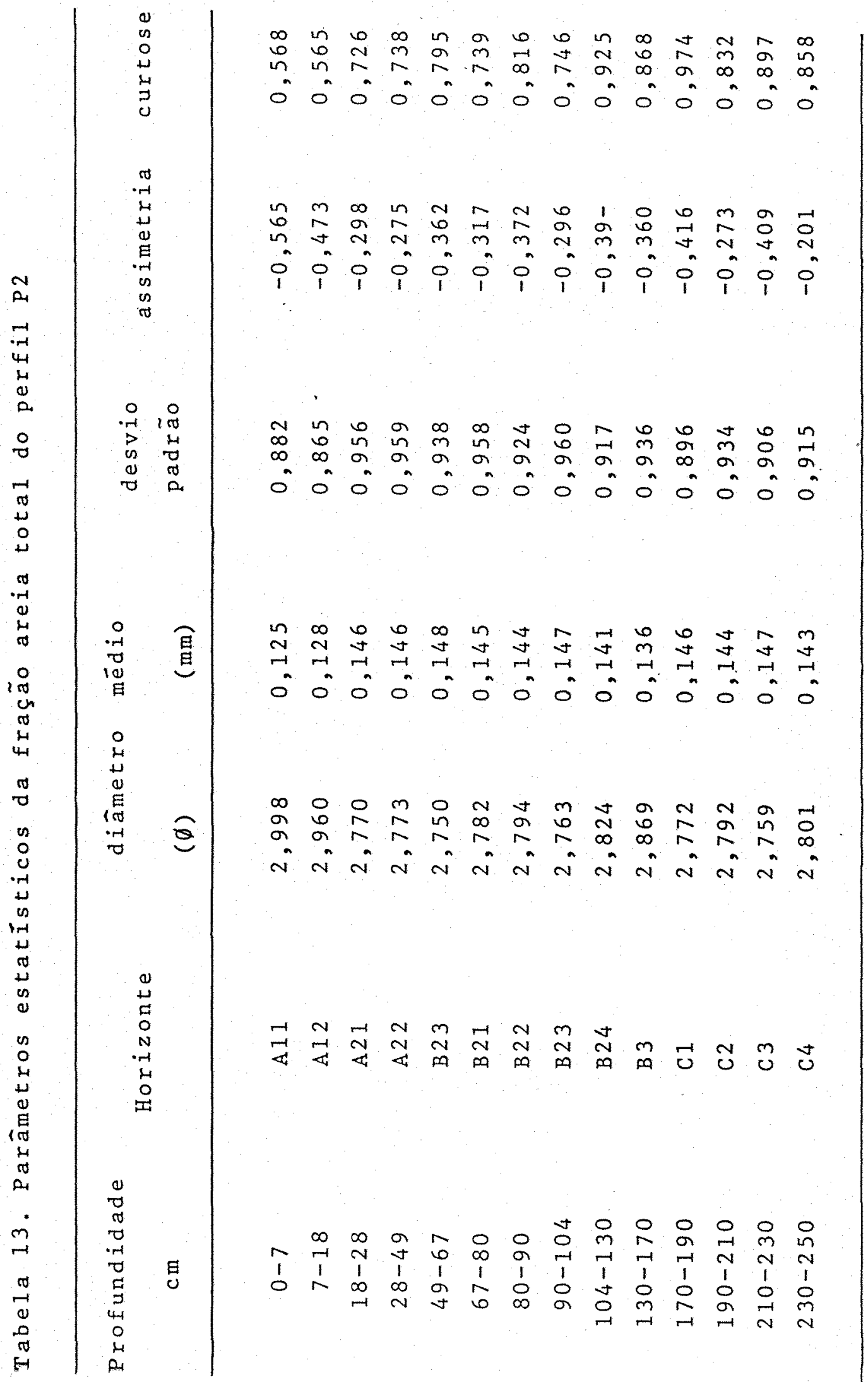




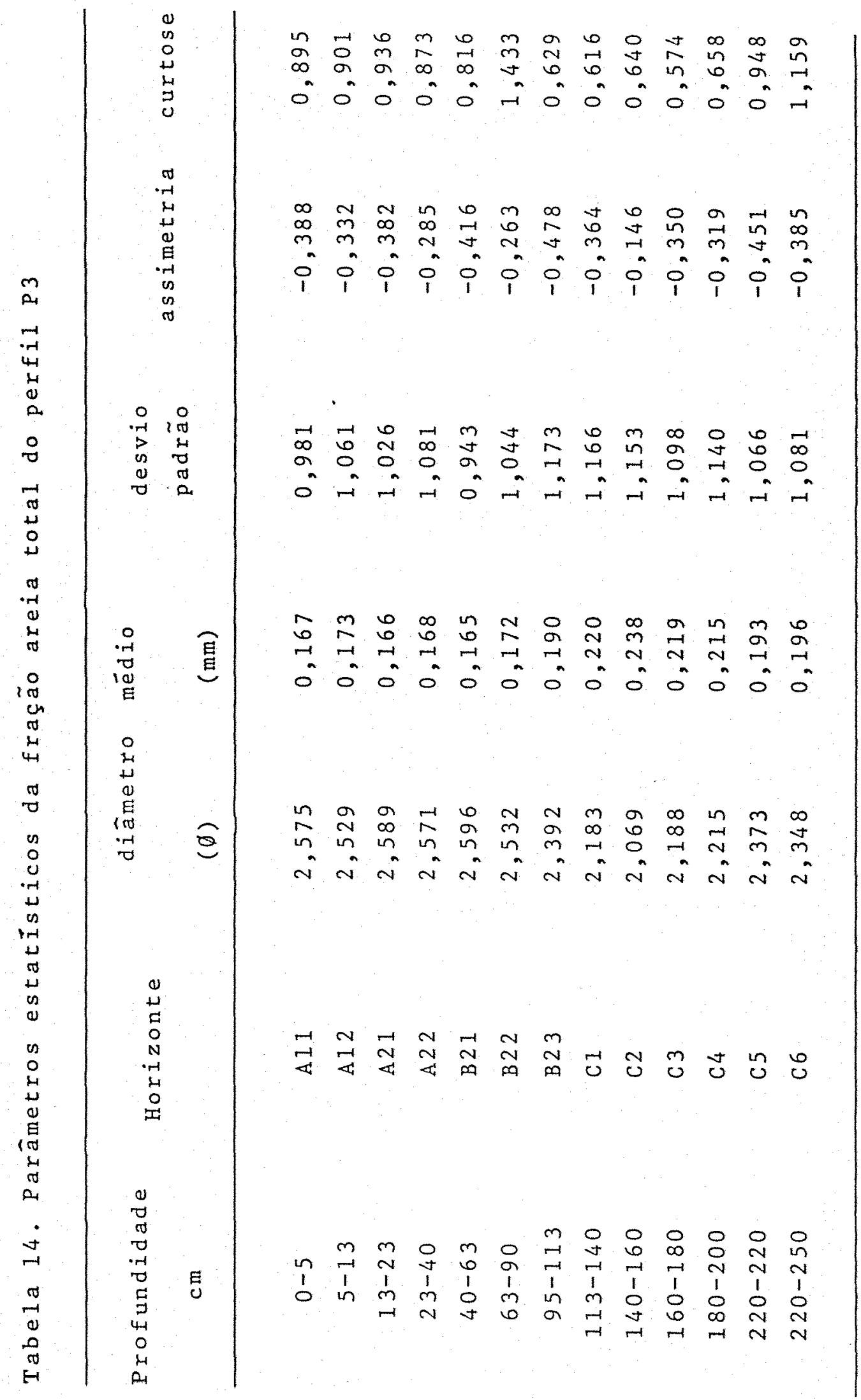




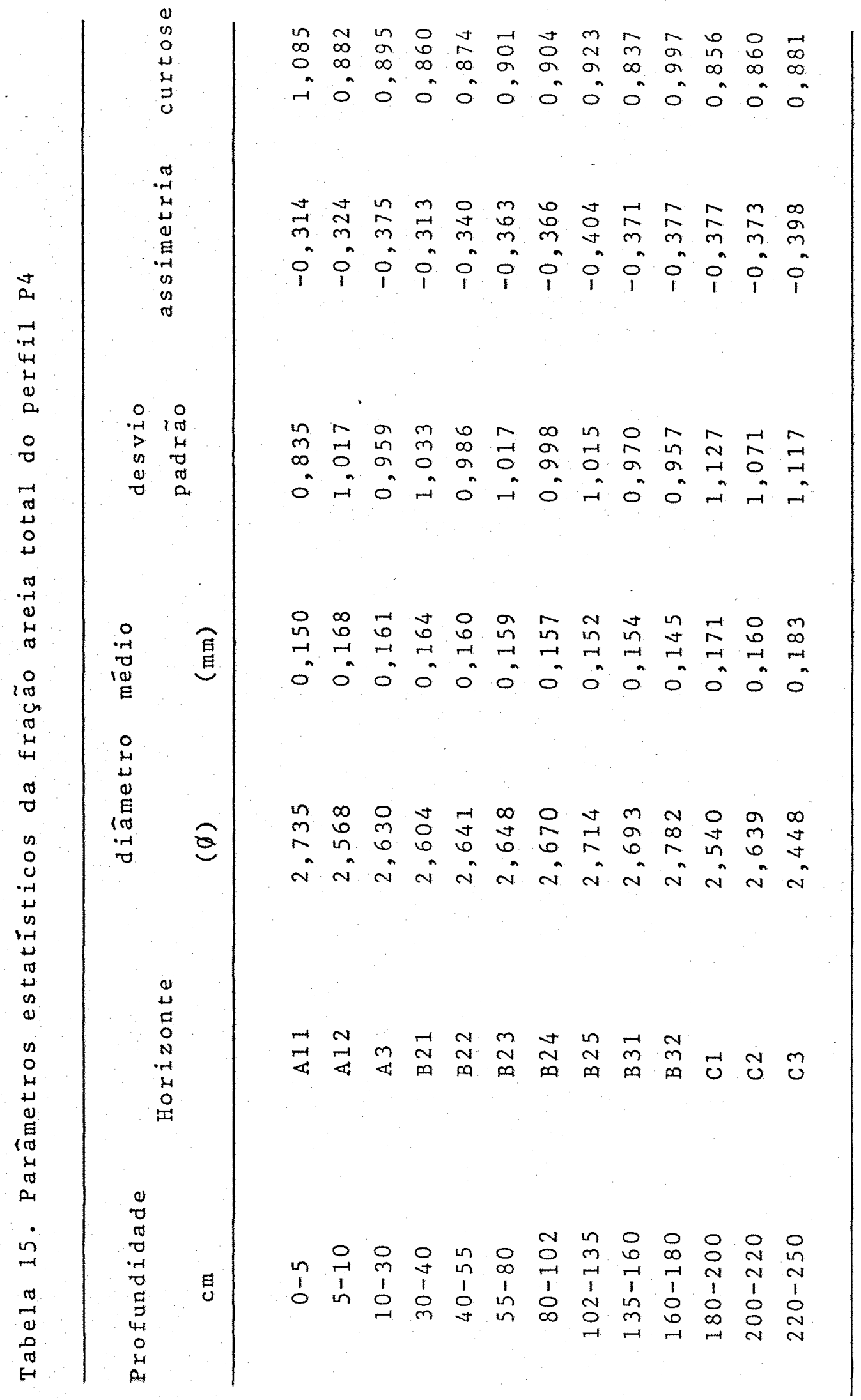




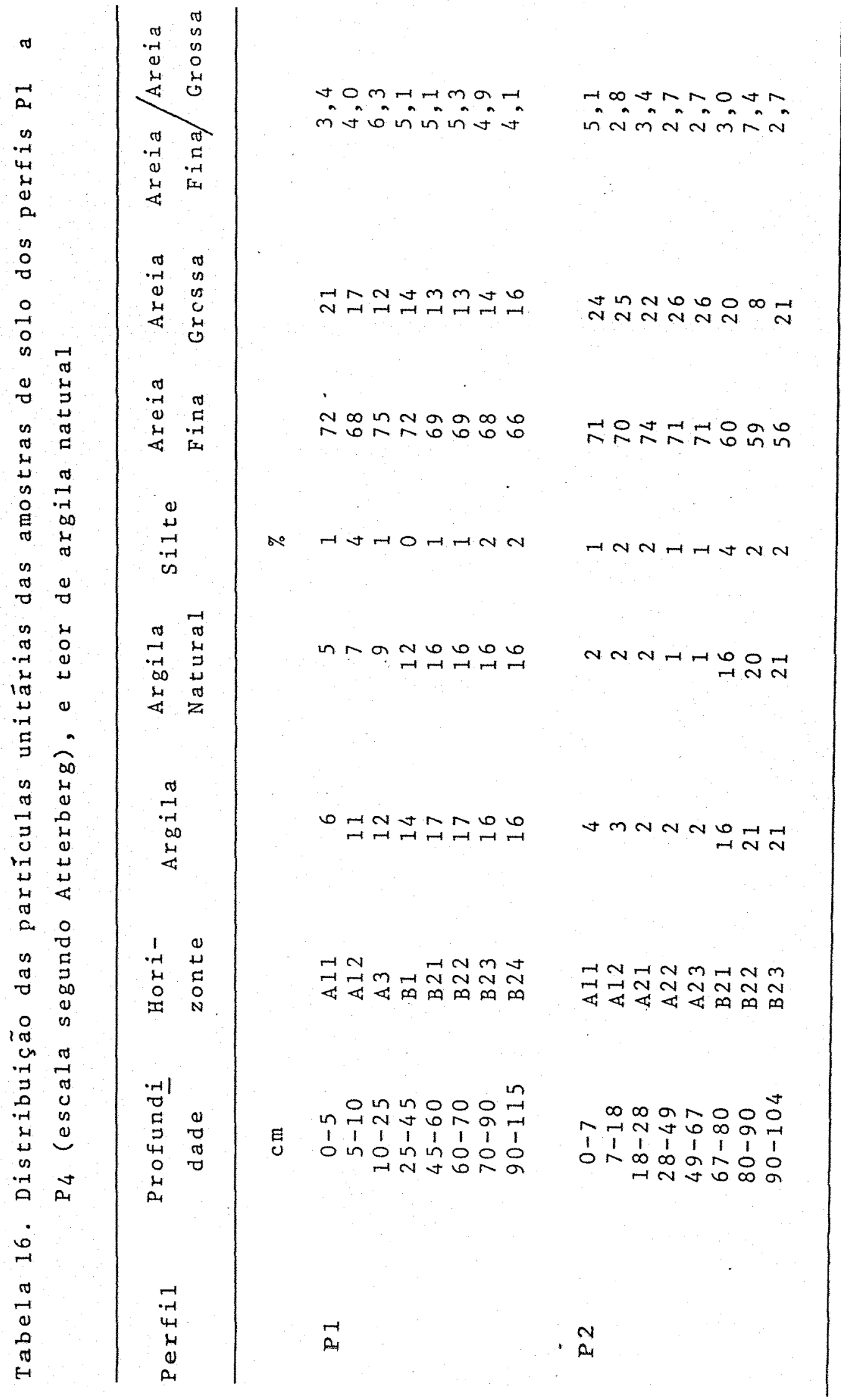




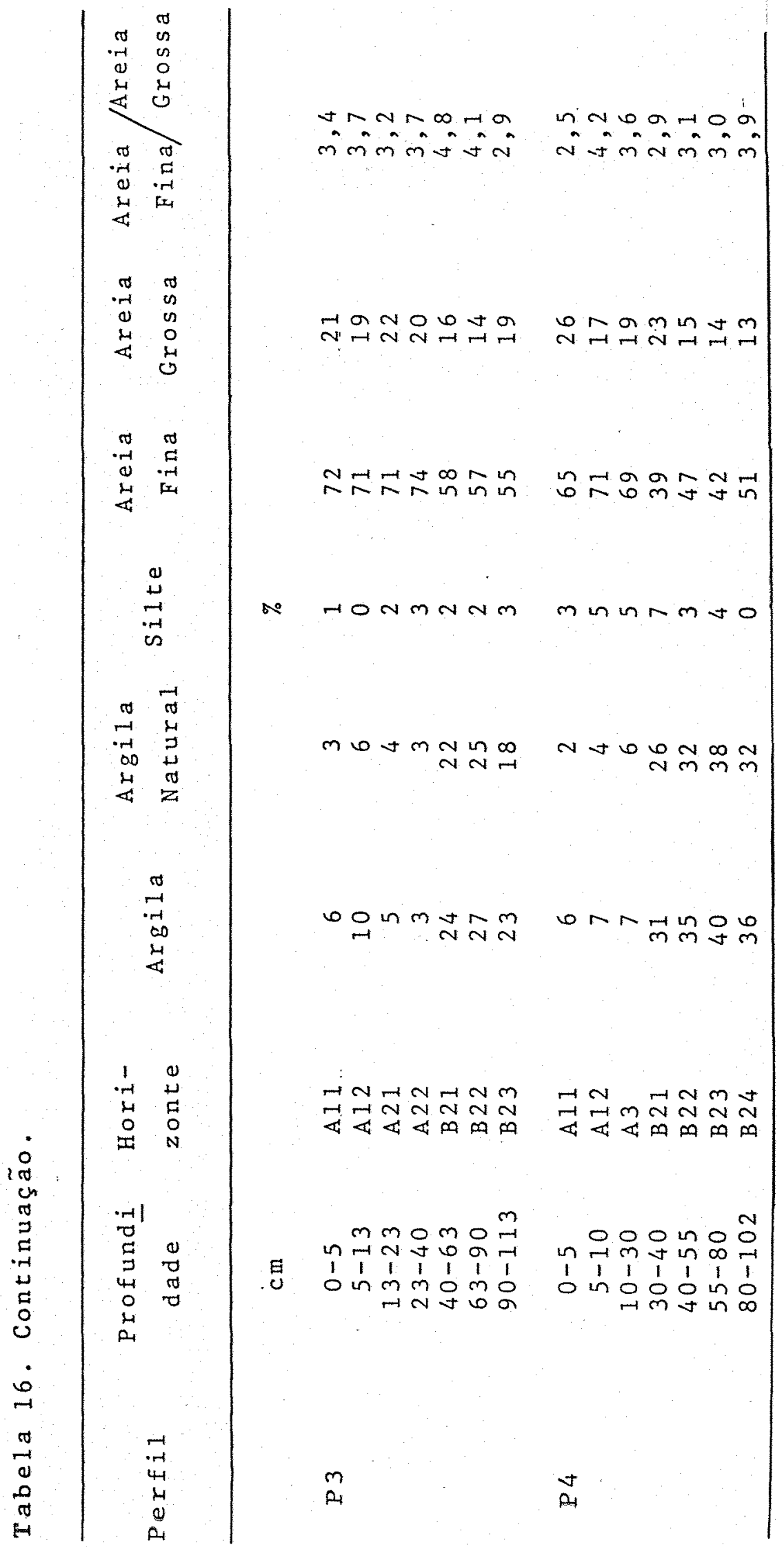




\subsubsection{Descrição Morfolögica}

No apendice encontram-se as descrições morfologicas detalhadas dos perfis.

No topo da encosta A o perfil PI apresenta hor zonte A moderado de $25 \mathrm{~cm}$ de espessura, coloração bruna acinzen tada no subhorizonte A11 (7,5YR 4/2) e bruna nos subhorizontes A12 e A3 (7,5YR 4/3, 4/4), respectivamente, classe textural areia ou areia franca, estrutura variando de granular pequena fraca a subangular media fracamente desenvolvida e consistência friāvel ou firme/friāve1, ligeiramente plástica e ligeiramente pegajosa. A transição entre os horizontes $A$ e $B$ é clara e plana. O horizonte $B$ possui cor laranja amarelada nos subhorizontes B1, B21 e B22 (1OYR $6 / 3,6 / 4$ e 6/5) e bruna amarelada clara no B23 e B24 (10YR 7/6 e 6/6), respectivamente. Sua clas se textural é areia franca ou franco arenosa, a estrutura subangular mēdia fraca e a consistência friāvel ou firme/friāvel (ümida), ligeiramente plástica e ligeiramente pegajosa (molhada).

No perfil P2, localizado na posição de meia encosta, o horizonte A bastante espesso $(67 \mathrm{~cm})$ apresenta coloração bruno amarelada acinzentada no sub horizonte AlI (IOYR 4/2), bruna no Al2 (7,5YR 4/4) e bruno amarelado acinzentado ou bruno no A21, A22 e A23 (7,5 ou 10YR 5/2 e 7,5YR 6/3), respectivamente. A transição entre os horizontes $A$ e $B$ é abrupta e ondulada. O horizonte B2 possui coloração brunada, bruno cla 
ra ou bruno amarelada (7,5YR 5/4,5/5), com mosqueamento pouco pequeno distinto bruno laranja amarelado ou bruno claro ( $7,5 Y R$ $5 / 7$ ou loYR $5 / 5,5 / 7$ e $6 / 3$ ).

o perfil p3, localizado na posição de terço inferior, morfologicamente se assemelha ao $P 2$, por $\overrightarrow{e m}$ tem estrutu ra e consistência seca e ümida mais desenvolvida no horizonte B 2 .

Na parte inferior do relevo, o perfil $P 4$ apresenta horizonte A moderado de $30 \mathrm{~cm}$ de espessura, cor ümida bru na acinzentada no AlI (7,5YR 4/2) e bruna no AI2 e Al3 (7,5YR $4 / 3$ e 5/3) respectivamente, estrutura granular pequena fraca e consistência friāvel (ūmida), não plàstica e não pegajosa (mo1hada). A transição entreos horizontes A e B è abrupta e plana. O horizonte $B$ apresenta classe textural franco argilosa ou argilo arenosa, estrutura subangular média moderadamente desen volvida, consistência firme (ümida), 1igeiramente plästica ou plástica e ligeiramente pegajosa. A cor è laranja amarelada no B21 (10YR 6/4), bruna no B22 e B24 (7,5YR 5/3 e 5/4) respectivamente, laranja no B24 (7,5YR 6/4) e bruno clarono B 25. (7,5YR 5/7). Todos esses horizontes apresentam mosqueamento pouco pequeno distinto bruno amarelado claro (10YR 6/6). A cerosidade comum a moderada reveste os agregados estruturais do horizonte B 2 . 
$5.1 .5 \cdot$ Anä1ise de morfoscopia

o graude: arredondamento dos grãos de quartzo da fração areia, que tem sido utilizado para decifrar eventos deposicionais, constitui-se como bom indicio de maturidade do se dimento e somente areias retrabalhadas a vārios ciclos sucessi vos $\vec{e}$ que apresentam grãos moderadamente ou bem arredondados.

A anälise de morfoscopia da fração areia muito fina $(0,125-0,062 \mathrm{~mm})$ revelou que no perfil $\mathrm{P} 4$ ha semelhança no grau de arredondamento entre os horizontes $A$ e $B$, os quais diferem do horizonte $C$, que apresenta areia menos arredondada. os valores de arredondamento médio encontrados no horizonte Al dos perfis da encosta $A$ (P1 ao P4) são, respectivamente, 0,67 , $0,61,0,73$ e 0,60 , no horizonte B2 $0,65,0,69,0,66$ e 0,58 e no horizonte C $0,50,0,50,0,62$ e 0,46 (Tabela 17). 
Tabela 17. Valores de arredondamento médio dos horizontes A, B e C dos perfis P1 a P4 (encosta A)

Horizonte

PERFIL

$\begin{array}{llll}\text { P1 } 1 & \text { P } 2 & \text { P } 3 & \text { P4 }\end{array}$

A 1

0,67

0,61

0,74

0,60

A 12

0,55

0,61

0,70

0,59

B 2

0,65

0,69

0,66

0,58

C

0,50

0,50

0,62

0,46

A figura 6 apresenta histogramas das classes de arredondamento da fração areia muito fina $(0,125-0,062 \mathrm{~mm})$ dos quatro perfis da encosta A. Nota-se nessa figura que no PVp (Perfil P4) hà maior frequência de valores mais altos de arredondamento da fração areia nos horizontes $A$ e $B$ do que no horizonte C. 

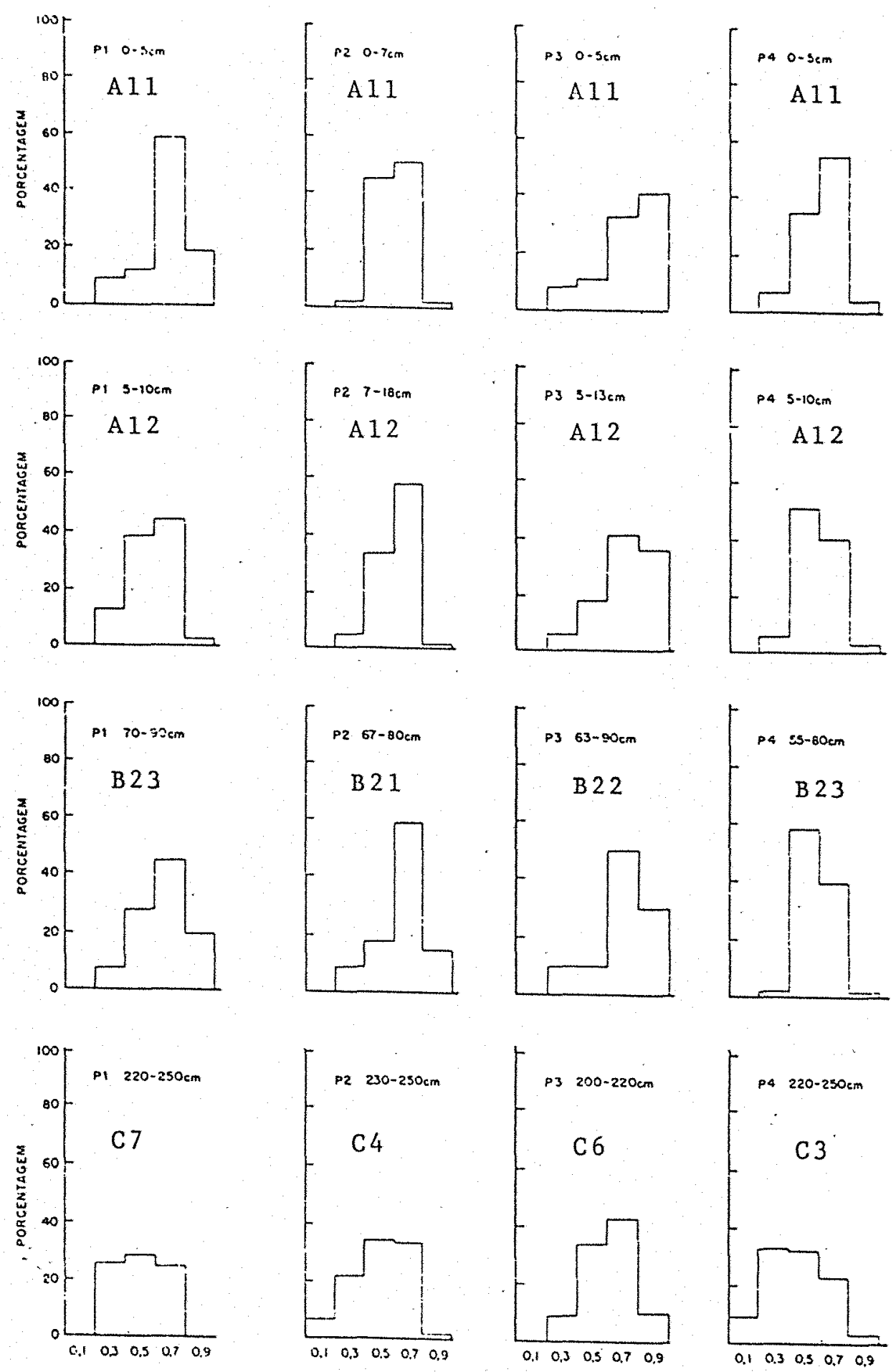

Figura 6. Histogramas da distribuição das classes de arredon damento da fração areia muito fina dos horizontes A, B e C dos perfis P1 a P4. 
5.1.6. Estudo. dos minerais pesados.

o estudo mineralögico da fração areia muito fina $(0,125-0,062 \mathrm{~mm})$ revelou que nas amostras de solo dos horizontes A, B e C dos quatro perfis da encosta A, os minerais pe sados predominantes são: zircão, turmalina e estaurolita. Ocor re, em geral, quantidade reduzida de rutilo e cianita (Tabela 18). Para se obter mais subsídios na verificação de um provāvel coluviamento no horizonte A do PVp (perfil P4) a partir do PVIs (P1, P2 e P3), foi feito estudo mineralógico (pesados) mais detalhados que o anterior, considerando-se caracteristicas de cor, do tipo prismático ou arredondado e da forma. (Tabe las 19 a 22). Os resultados obtidos nesse estudo mostraram cer ta semelhança na quantidade de turmalina castanha, verdee azul com relação ao horizonte A do perfil PI (Tabela 19) e ao horizonte A do perfil p4 (Tabela 21) e grande diferença com referência ao horizonte B do perfil P4 (Tabela 22), sugerindo depo sição de material grosseiro no horizonte A do PVp a partir do pvis, que está situado na posição mais alta do relevo. 
Tabela 18. Frequências porcentuais dos minerais pesados trans parentes referentes aos perfis de solo da encosta A (fração $0,125-0,062 \mathrm{~mm}$ ).

Perfil Profun Estau-
didade rolita Rutilo Cianita

\begin{tabular}{|c|c|c|c|c|c|c|c|}
\hline & $\mathrm{cm}$ & & & & & & \\
\hline \multirow{4}{*}{ P 1} & $0-5$ & 32 & 1 & 0 & 54 & 60 & 0,9 \\
\hline & $5-10$ & 8 & 1 & 0 & 64 & 27 & 2,4 \\
\hline & $70-90$ & 12 & 3 & 0 & 65 & 20 & 3,3 \\
\hline & $90-115$ & 7 & 3 & 0 & 76 & 14 & 5,4 \\
\hline \multirow[t]{3}{*}{$\mathrm{P} 2$} & $0-7$ & 17 & 2 . & 0 & 65 & 26 & 2,5 \\
\hline & $7-18$ & 5 & 1 & 0 & 52 & 42 & 1,2 \\
\hline & $67-80$ & 9 & 0 & 0 & 52 & 39 & 1,3 \\
\hline \multirow[t]{4}{*}{ P 3} & $0-5$ & 6 & 1 & 0 & 70 & 23 & 3,0 \\
\hline & $5-13$ & 6 & 6 & 0 & 77 & 12 & 6,4 \\
\hline & $95-113$ & 9 & 16 & 0 & 48 & 23 & 2,1 \\
\hline & $113-140$ & 8 & 1 & 0 & 42 & 8 & 5,2 \\
\hline \multirow[t]{4}{*}{$\mathrm{P} 4$} & $0-5$ & 9 & 2 & 6 & 48 & 35 & 1,4 \\
\hline & $5-10$ & 12 & 7 & 0 & 52 & 28 & 1,9 \\
\hline & $55-80$ & 6 & 4 & 2 & 74 & 14 & 5,3 \\
\hline & $80-102$ & 23 & 0 & 0 & 50 & 27 & 1,9 \\
\hline
\end{tabular}


Tabela 19. Espécies de minerais pesados transparentes na amostra de areia muito fina $(0,125-0,088 \mathrm{~mm})$ do horizonte $A 1(0-5 \mathrm{~cm})$ do perfil P1

\begin{tabular}{lccc}
\hline Mineral & Tipo & de & Grãos \\
& 1 & 2 & 3 \\
& & & \\
Turmalina castanha * & 1,0 & 39,0 & 33,0 \\
Turmalina verde * & 0,0 & 7,0 & 10,0 \\
Turmalina azul * & 0,0 & 1,0 & 3,0 \\
Turmalina incolor * & 0,0 & 0,0 & 0,0 \\
Zircáo * & 2,0 & 34,0 & 47,0 \\
Estaurolita ** & 2,0 & 14,0 & 8,0 \\
Rutilo *** & 1,0 & 2,0 & 0,0 \\
\hline
\end{tabular}

\section{Tipo de grãas}

* $\quad 1$ - Prismātico bipiramidal

2 - Prismático com terminaçōes piramidais arredondadas

3. Arredondado

$* * 1$ - Sem alteração

2 - Pouco alterada

3 - Muito alterada

$* * * \quad 1$ - Forma não prismática

2 - Forma prismātica. 
Tabela 20. Espēcies de minerais pesados transparentes na amostra de areia muito fina $(0,125-0,088 \mathrm{~mm})$ do horizonte B $21(70-90 \mathrm{~cm})$ do perfil P1

\begin{tabular}{lccc}
\hline & Tipos & de & Grãos \\
Mineral & 1 & 2 & 3 \\
& & $\%$ & \\
& & 5,0 & 5 \\
Turmalina castanha * & 0,0 & 2,0 & 0,5 \\
Turmalina verde * & 0,0 & 1,0 & 1,0 \\
Turmalina azul * & 0,0 & 0,0 & 0,0 \\
Turmalina incolor & 0,0 & 17,5 & 4,0 \\
Zircäo * & 2,0 & 9,0 & 4,5 \\
Estaurolita ** & 1,0 & 0,5 & 0,0 \\
Rutilo *** & 1,5 & & 5 \\
\hline
\end{tabular}

Tipos de grãos

* $\quad 1$ - Prismätico bipiramidal

2 - Prismātico com terminações piramidais arredondadas

3 - Arredondado

** $\quad 1-$ Sem alteração

2 - Pouco alterado

3 - Muito alterado

$* * * 1$ - Forma não prismātica

2 - Forma prismātica 
Tabela 21. Espécies de minerais pesados transparentes na amostra de areia muito fina $(0,125-0,088 \mathrm{~mm})$ do horizonte A1 $(0-5 \mathrm{~cm})$ do perfil P4.

\begin{tabular}{lccc}
\hline Mineral & Tipos & de & Grãos \\
& 1 & 2 & 3 \\
& & $\%$ & 28,0 \\
Turmalina castanha * & 1,0 & 36,0 & 8,0 \\
Turmalina verde * & 0,0 & 9,0 & 0,0 \\
Turmalina azul * & 0,0 & 1,0 & 0,0 \\
Turmalina incolor * & 0,0 & 0,0 & 45,0 \\
Zircão * & 6,0 & 66,0 & 2,0 \\
Estaurolita ** & 10,0 & 16,0 & 0,0 \\
Rutilo *** & 9,0 & 3,0 & \\
\hline
\end{tabular}

Tipos de grãos

* 1 - Prismätico bipiramidal

2 - Prismātico com terminações piramidais arredondadas

3 - Arredondado

** 1 - Sem alteração

2 - Pouco alterado

3 - Muito alterado

$* * * 1-$ Forma não prismätica

2 - Forma prismātica 
Tabela 22. Espécies de minerais pesados transparentes na amostra de areia muito fina $(0,125-0,088 \mathrm{~mm})$ do horizonte B21 $(55-8,0 \mathrm{~cm})$ do perfil p4

\begin{tabular}{lccc}
\hline Mineral & Tipos & de & Grãos \\
& 1 & 2 & 3 \\
& & $\%$ & 7,0 \\
Turmalina castanha * & 0,0 & 5,0 & 0,5 \\
Turmalina verde * & 0,0 & 0,5 & 0,0 \\
Turmalina azul * & 0,0 & 0,5 & 0,0 \\
Turnalina incolor * & 0,0 & 0,0 & 48,0 \\
Zircão * & 2,5 & 24,5 & 1,0 \\
Estaurolita ** & 2,5 & 4,5 & 0,0 \\
Rutilo *** & 2,0 & 1,5 & \\
\hline
\end{tabular}

Tipos de grãos

* $\quad 1$ - Prismático bipiramidal

2 - Prismático com terminações piramidais arredondadas

3 - Arredondado

$* * \quad 1$ - Sem alteração

2 - Pouco alterada

3 - Muito alterada

*** 1 - Forma não prismätica

2 - Forma prismātica 


\section{Relação Zircão/Turmalina ( $/ T$ T)}

A uniformidade de material de origem pode ser determinada pela constância da relação de dois minerais resis tentes ao intemperismo (BREWER, 1977). Os valores da relação zircão/turmalina do perfil P4 (Tabela 18) tem variações entre os horizontes $A$ e B, sugerindo ter ocorrido deposição de mate rial de outra fonte, mas hä de se considerar que essa relação também varia no horizonte B, indicando que o material de origem.é formado por diversos estratos sedimentares, cujos conta tos, não necessariamente, coincidem com os atuais 1imites entre os horizontes $A$ e B. Isto $\vec{e}$ hä probablilidade de ocorrên cia de descontinuidades em värias partes do perfil e, por isso, sua ocorrência entre o horizonte A e o B não é suficiente para explicar o abrupto aumento de argila no perfil P4. 


\subsubsection{Ferro}

Foram feitas anāitses de ferro extraídos pelo método do ditionito nos quatro pexfis da encosta A (P1, P2, P3 e P4). Para o perfil P4, que representa o solo mais relacionado ao problema estudado, além do ferrolivre, foram feitas anälises adicionais de ferro, com extrações pelos métodos do äcido sulfūrico e oxalato. Com esses dados, foram feitas relações ferro-ditionito/ferro-total (Fe-d/Fe-t), ferro-oxala to/ferro-ditionito (Fe-ox/Fe-d) e ferro-ditionito/argila (Tabe 1 as 23 e 24 l.

A relação Fe-ox/Fe-d indica o domínio das formas cristalinas de ferro e admite-se que todo ferro extraido pelo oxalato de amonio provenha da ferridrita (SCHWERTMANN et a1ii, 1982).

observando a figura $\dot{7}$, nota-se que as relações Fe-d/Fe-t e Fe-d/argila são praticamente uniformes em profundidade e que a relação Fe-ox/Fe-d apresenta uma distribuição bem diferente, dado o acentuado decrëscimo dessa relação, pas sando na superfície de 0,4 para 0,1 em profundidade. A diminuição da relação Fe-ox/Fe-d em profundidade indica que formas melhor cristalizadas de ferro se encontram nos horizontes de subsuperfície (DEMATTE, 1975). Segundo SCHWERTMANN

a presença de matéria orgânica na superficie retarda a taxa de cristalização de óxidos e hidróxidos de ferro. 


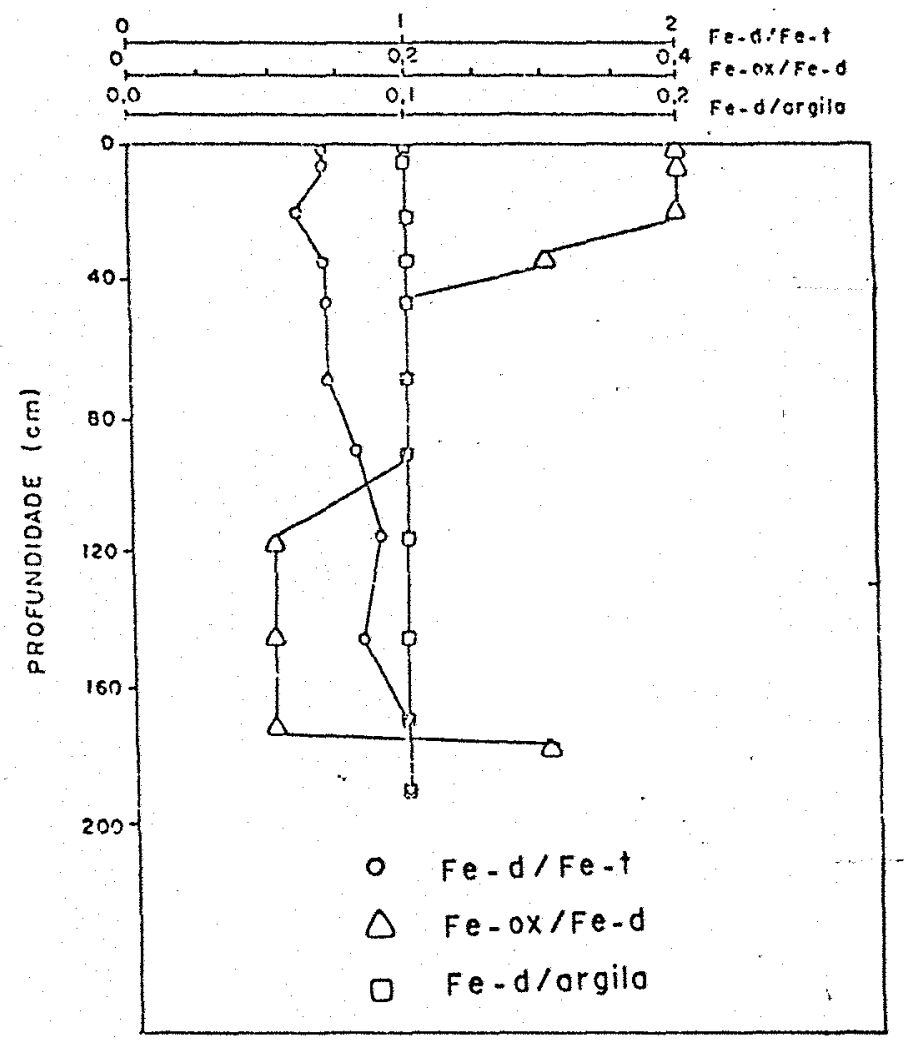

Figura 7. Relações ferro-ditionito/ferro-total (Fe-d/Fe-t), ferro-oxalato/ferro-ditionito (Fe-ox/Fe-d) e ferro-ditionito/argila (Fe-d/argila) do perfil P 4. 
Tabela 23. Ferro extraído pelo método do ditionito (Fe-d), teor de argila e relação Fe-d/argila dos perfis P1, P2, e P 3 .

Perfil $\begin{gathered}\text { Profundi } \\ \text { dade }\end{gathered}$ Horizonte Fe-d Argila Fe-d/Argila

\begin{tabular}{|c|c|c|c|c|c|}
\hline & $\mathrm{cm}$ & & $\%$ & $\%$ & \\
\hline \multirow[t]{11}{*}{ P 1} & $0-5$ & A11 & 0,25 & 6 & 0,03 \\
\hline & $5-10$ & $\mathrm{~A} 12$ & 0,36 & 11 & 0,02 \\
\hline & $10-25$ & A 3 & 0,54 & 12 & 0,03 \\
\hline & $25-45$ & B 1 & 0,61 & 14 & 0,03 \\
\hline & $45-60$ & B 21 & 0,71 & 17 & 0,03 \\
\hline & $60-70$ & B 22 & 0,72 & 17 & 0,03 \\
\hline & $70-90$ & B 23 & 0,76 & 16 & 0,03 \\
\hline & $90-115$ & B 24 & 0,71 & 16 & 0,03 \\
\hline & $115-130$ & $\mathrm{C} 1$ & 1,30 & 17 & 0,05 \\
\hline & $130-145$ & $\mathrm{C} 2$ & 1,15 & 17 & 0,05 \\
\hline & $145-160$ & C 3 & 1,44 & 20 & 0,05 \\
\hline \multirow[t]{14}{*}{$\mathrm{P} 2$} & $0-7$ & A11 & 0,29 & 4 & 0,05 \\
\hline & $7-18$ & A 12 & 0,23 & 3 & 0,05 \\
\hline & $18-28$ & A 21 & 0,23 & 2 & 0,08 \\
\hline & $28-49$ & A 22 & 0,19 & 2 & 0,07 \\
\hline & $49-67$ & A23 & 0,21 & 2 & 0,08 \\
\hline & $67-80$ & B 21 & 1,23 & 16 & 0,05 \\
\hline & $80-90$ & B 22 & 1,30 & 21 & 0,04 \\
\hline & $90-104$ & B 23 & 1,50 & 21 & 0,05 \\
\hline & $104-130$ & B 24 & 1,89 & 30 & 0,05 \\
\hline & $130-170$ & B 3 & 1,87 & 28 & 0,05 \\
\hline & $170-190$ & $\mathrm{C} 1$ & 1,61 & 23 & 0,05 \\
\hline & $190-210$ & $\mathrm{C} 2$ & 1,61 & 22 & 0,05 \\
\hline & $210-230$ & C 3 & 1,24 & 19 & 0,05 \\
\hline & $230-250$ & $\mathrm{C} 4$ & 1,21 & 18 & 0,05 \\
\hline
\end{tabular}


Tabela 23. Continuação.

\begin{tabular}{|c|c|c|c|c|c|}
\hline Perfil & $\begin{array}{c}\text { Profund } \underline{i} \\
\text { dade }\end{array}$ & Horizonte & $F e-d$ & Argila & $\mathrm{Fe}-\mathrm{d} / \mathrm{Argila}$ \\
\hline & $\mathrm{cm}$ & & $\%$ & $\%$ & \\
\hline \multirow[t]{11}{*}{ P 3} & $0-5$ & A11 & 0,46 & 6 & 0,06 \\
\hline & $5-13$ & A 12 & 0,48 & 10 & 0,03 \\
\hline & $13-23$ & A 21 & 0,48 & 5 & 0,07 \\
\hline & $23-40$ & A 22 & 0,35 & 3 & 0,08 \\
\hline & $40-63$ & B 21 & 1,87 & 24 & 0,06 \\
\hline & $63-90$ & B 22 & 2,33 & 27 & 0,06 \\
\hline & $90-113$ & B 23 & 1,19 & 23 & 0,06 \\
\hline & $113-140$ & C 1 & 2,00 & 20 & 0,10 \\
\hline & $140-160$ & $\mathrm{C} 2$ & 1,14 & 17 & 0,07 \\
\hline & $160-180$ & C 3 & 1,52 & 16 & 0,10 \\
\hline & $180-200$ & $\mathrm{C} 4$ & 1,46 & 16 & 0,10 \\
\hline
\end{tabular}




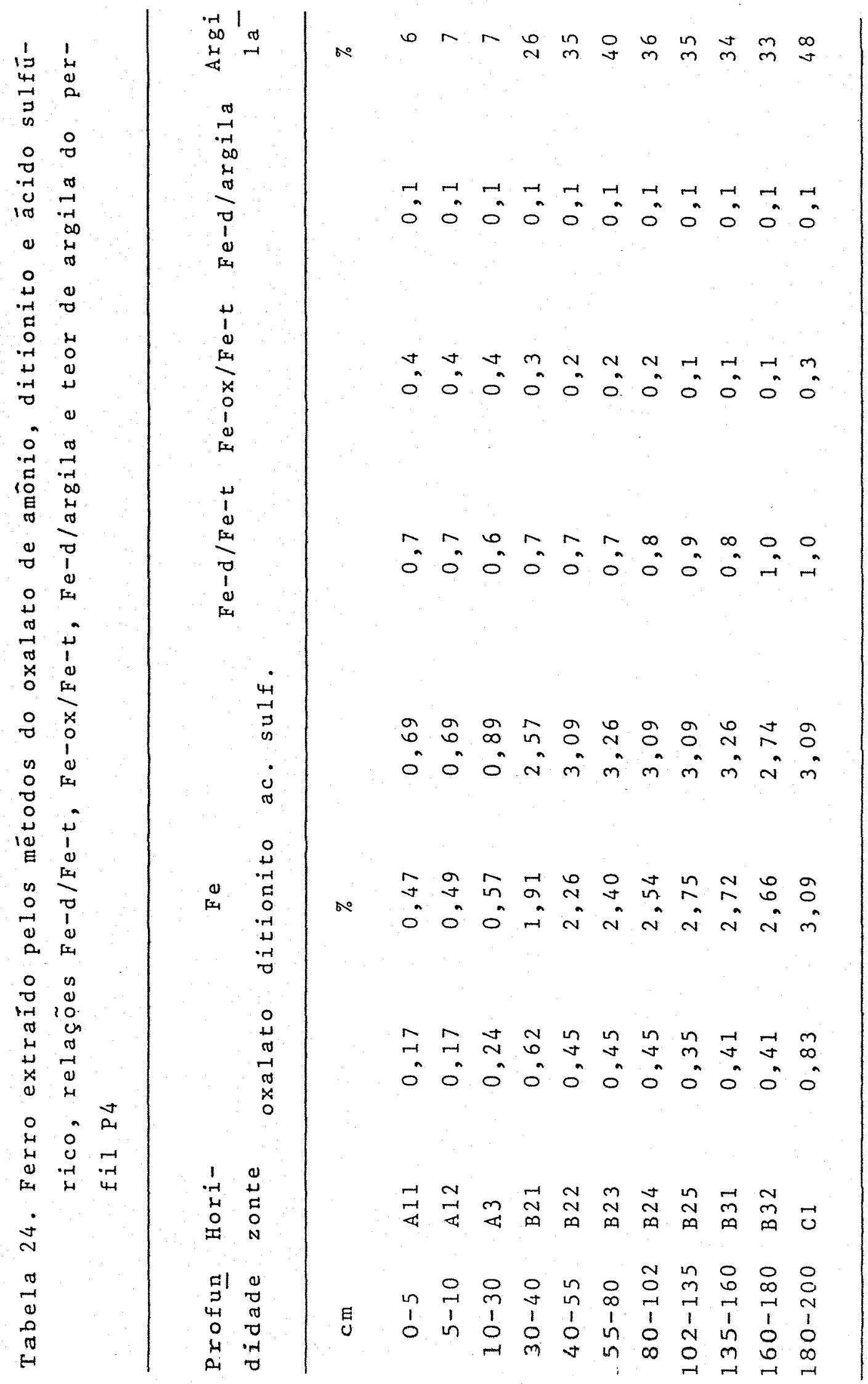




\subsection{Encosta B}

\subsubsection{Anāitises quimicas}

\section{a) $\mathrm{pH}$ em àgua}

A amplitude de variação dos valores de pH ägua verificado no horizonte $A$, são os seguintes: 5,7 a 6,8 (P5), 5,7 a $6,7(\mathrm{P} 6)$, e 5,6 a 5,9 (P7), sendo que o grau de acidez se eleva com o aumento da profundidade. $0 \Delta p H$ apresenta sinal negativo nos três perfis indicando dominânciadecarganegativa.

b) Carbono

os maiores valores de carbono na superfície estão relacionados com a adição de matéria orgânica pelo processo de decomposição do sistema radicular das plantas.

c) Soma e saturação em bases

os valores de soma de bases oscilam entre 0,4 a 4,9 meq/100g TFSA em superficie diminuindo em profundidade (P5 e P7) e aumentando (P6) em profundidade. Os valores de saturação em bases variam de 33 a $58 \%$ no horizonte superficial diminuindo nos horizontes sub superficiais. 
d) Capacidade de troca de cátions e saturação em alumínio

Dos três perfis dessa encosta somente o perfil P5 possui argila de atividade alta, e o caráter älico estā pre sente em todos eles.

As tabelas 25 a 27 apresentam as caracteristicas químicas dos perfis P 5 ao P7 .

\subsubsection{Anālise granulométrica}

o perfil p5 possui valores quasenulos dasareias grossa e muito grossa e as areias média e fina contribuem com valores variando de 37 a $59 \%$ da areia total ao longo do perfil. o valor de argila $\vec{e}$ de apenas $2,0 \%$ no horizonte Al1 e aumenta para $26,4 \%$ no horizonte B21 (Tabela 28).

o exame dos dados granulométricos do perfil P6 aponta valores desprezíveis de areia grossa e muito grossa ao longo do perfil. As areias média e fina representam 33 a $72 \%$ da areia total. A fração argila assume valor de $4,6 \%$ no ho rizonte A e 15,1\% no horizonte B21 (Tabela 29).

o perfil P7 apresenta teores de areia grossa e muito grossa bastante reduzidas ao longo do perfil com valores inferiores a $1 \%$. Os valores de areia total variam de 63 a $81 \%$ no horizonte A, 28 a $50 \%$ no horizonte B, e no horizonte C O 
teor e de apenas $12 \%$. Em relação a areia total as areias média e fina são as que predominam sobre os demais com valores que variam de 65 a $76 \%$ no horizonte A, 63 a $74 \%$ no horizonte B. No horizonte $\mathrm{C}$ o valor é de $71 \%$. 0 teor de areia grossa não ultra passa a $1 \%$ ao longo do perfil e o de areia muito grossa é de apenas $0,2 \%$ nos horizontes 322 e $B 23$.

o valor de argila è de $9,5 \%$ no horizonte Al e se eleva para 27,3 no horizonte B21. Na rocha (folhelho) os teo res de areia muito grossa, grossa e média são nulos (Tabela $30)$.

Todos os perfis da encosta $B$ apresentam o caräter abrüptico.

\subsubsection{Anāilse estatistica}

No horizonte A1 dos perfis P5 ao P7 os valores de diâmetro médio da fração areia correspondem, respectivamente, a $0,20,0,19$ e $0,19 \mathrm{~mm}$, no horizonte B21 assumem..0,19, 0,18 e $0,18 \mathrm{~mm}$ e no C1 $0,19,0,17$ e $0,18 \mathrm{~mm}$. Os valores do desvio padrão são do P5 ao P7 de $0,677,0,739$ e 0,791 (horizonte AI), $0,720,0,792$ e 0,830 (horizonte B21) e $0,731,0,817$ e 0,875 (ho rizonte (1), respectivamente. Quanto ao grau de seleção esses sedimentos classificam-se como moderadamente selecionados nos horizontes A1, B21 e C1. A assimetria é positiva em todos hor zontes dos três perfis dessa encosta, logo a cauda da distri- 
buição da areia se encontra do lado das areias mais finas. A curtose apresenta no horizonte Al valor classificado mesocúrti co (P5), platicūrtico (P6) e mesocūrtico (P7). Nos horizontes A e B21 os valores enquadram-se como mesocūrtico e no horizonte Cl como platicūrtico.

As tabelas 31 a 33 apresentam os dados estatisticos dos horizontes A, B e C relativos aos perfis da encosta B $($ P 5 ao P7).

$$
\text { Observando-se as figura } 8 \text { a } 12 \text { relativa ao peI }
$$

fil P7 que foi escolhido para representar o PVp, nota-se clara mente o contraste de grosseiros entre a rocha (folhelho) e o solo, indicando que esse solo certamente teve contribuiçào de material externo.

Nessas figuras observa-se tambēm o menor tamanho de areia do horizonte B2, em relação ao horizonte A e B 3 , mas trata-se de fotografia de uma amostra de solo que não represen ta o valor de diâmetro médio (Mz) obtido na população analisada granulometricamente, a qual revelou valöres pröximos de diâ metro médio entre os horizontes $A, B$ e C. 
5.2.4. Descrição Morfolögica

Na parte superior da encosta B o perfil P5 apre senta horizonte A moderado bastante espesso ( $90 \mathrm{~cm}$ ), subdividido em Al1 e A12, de coloração bruna $(7,5 Y R 4 / 2,4 / 3)$, e A21, A22 (álbicos) com coloração bruno acinzentada e cinza brunada $(7,5 Y R 6 / 2,7 / 2)$, respectivamente. A classe textural é areia e a consistência solta (ūmida), não plästica e não pegajosa (mo1hada). A estrutura é granular pequena fracamente desenvolvida (A11) e em grãos simples nos sub horizontes A21 e A22. A transição para o horizonte B é abrupta e ondulada.

No horizonte B2 a classe textural è franco arenosa ou franco argilo arenosa, a cor é bruna nos sub horizontes B 31, B 22 е B23(7,5YR $5 / 3,6 / 6$ e $5 / 5$, respectivamente), com mosqueamento pouco distinto de $\operatorname{cor} 1$ aranja (7,5YR 6/6). A estrutura dos blocos è do tipo subangular, de tamanho médio e grau fraco de desenvolvimento e consistência friävel (ümida), ligeiramente plästica e ligeiramente pegajosa (molhada).

o perfil P6 assemelha-se ao P5 nas suas caracte risticas morfolögicas,

Na posição de meia encosta o perfil p7 possui horizonte A moderado com espessura de $20 \mathrm{~cm}$, cor bruna ou bruna acinzentada $(7,5 \mathrm{YR} 4 / 2,4 / 3)$, classe textural areia franca, es trutura subangular média fracamente desenvolvida e consistência friāvel (ūmida), ligeiramente plästica e ligeiramente pega 
josa (mo1hada).

O horizonte $B 2$ apresenta classe textural franco argilo arenosa ou argilo arenosa, coloração bruna no B2l e B22 $(7,5 Y R 5 / 4$ e 5/5) ou bruno c1ara no B23 e B24 (7,5YR 4/5 ou $5 / 7)$ com mosqueamento pouco pequeno distinto laranja (7,5YR 6/6), estrutura subangular média fortemente desenvolvida e consistência firme (ümida), ligeiramente plástica e ligeiramen te pegajosa (molhada). A cerosidade é comum e moderada no sub horizonte B31, pouca/comum e moderada nos sub horizontes B22 e B23 e pouco fraca no B24.

No apêndice se encontram as descrições morfologicas mais detalhadas dos perfis P5, P6 e P7. 


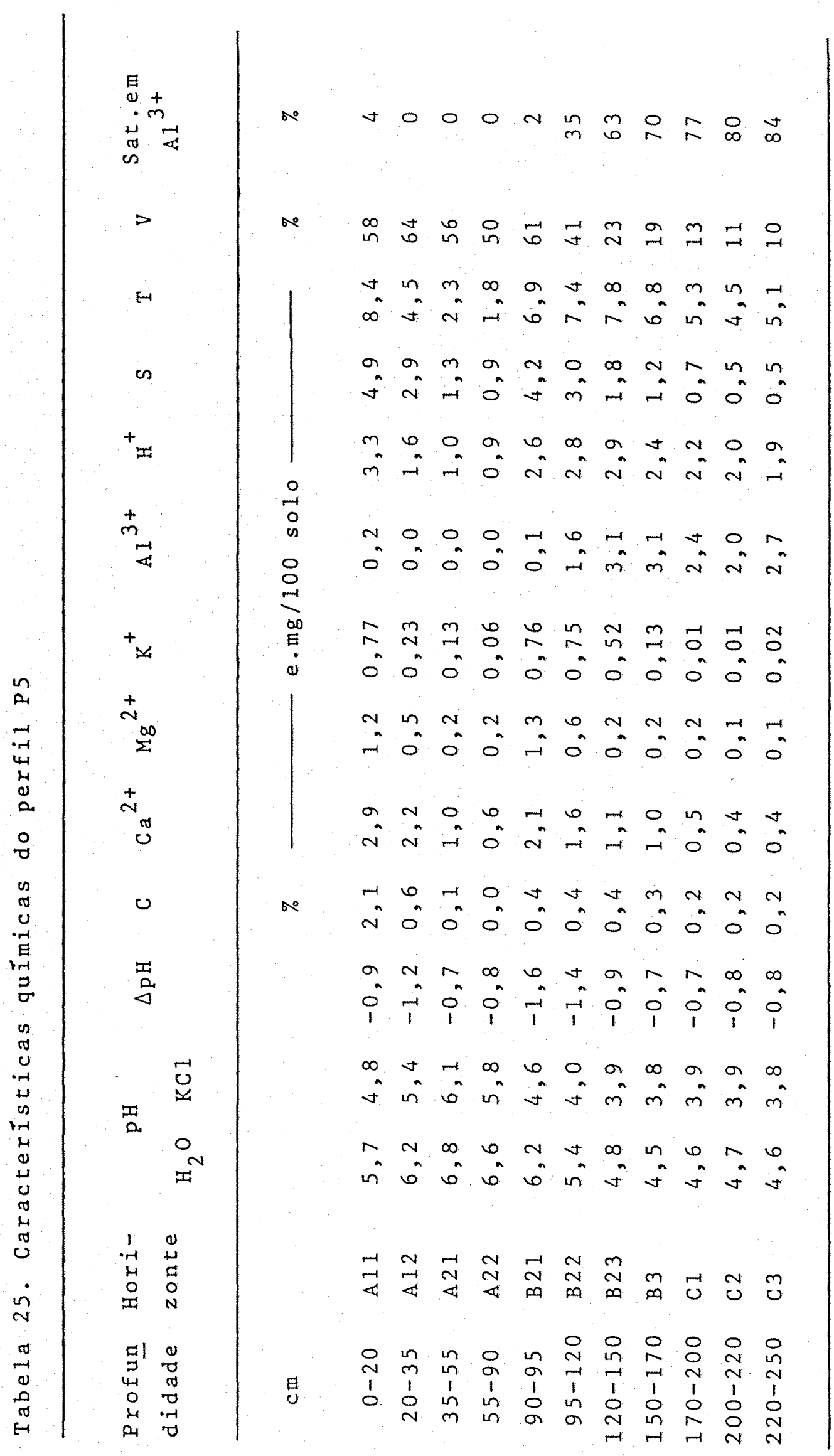




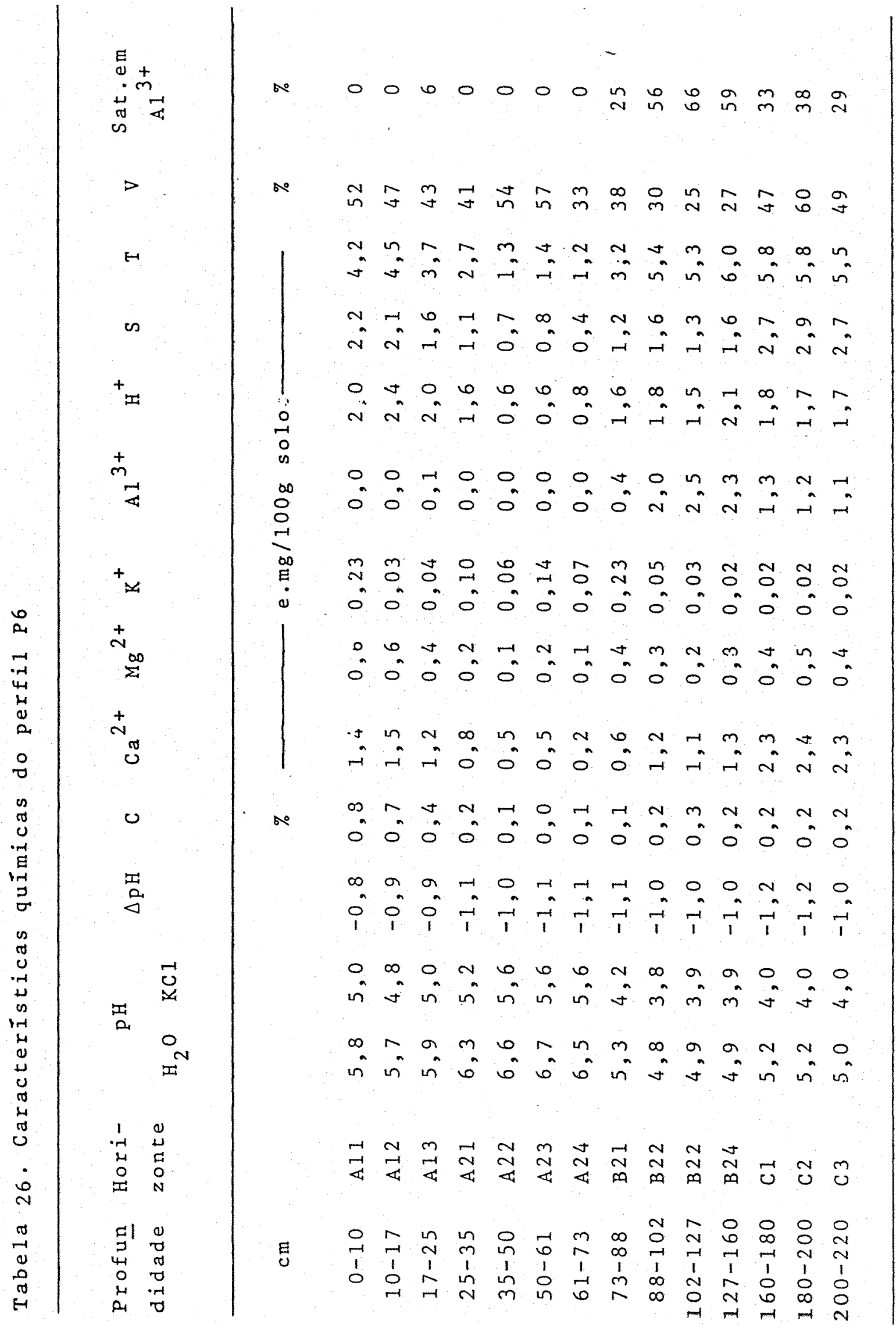




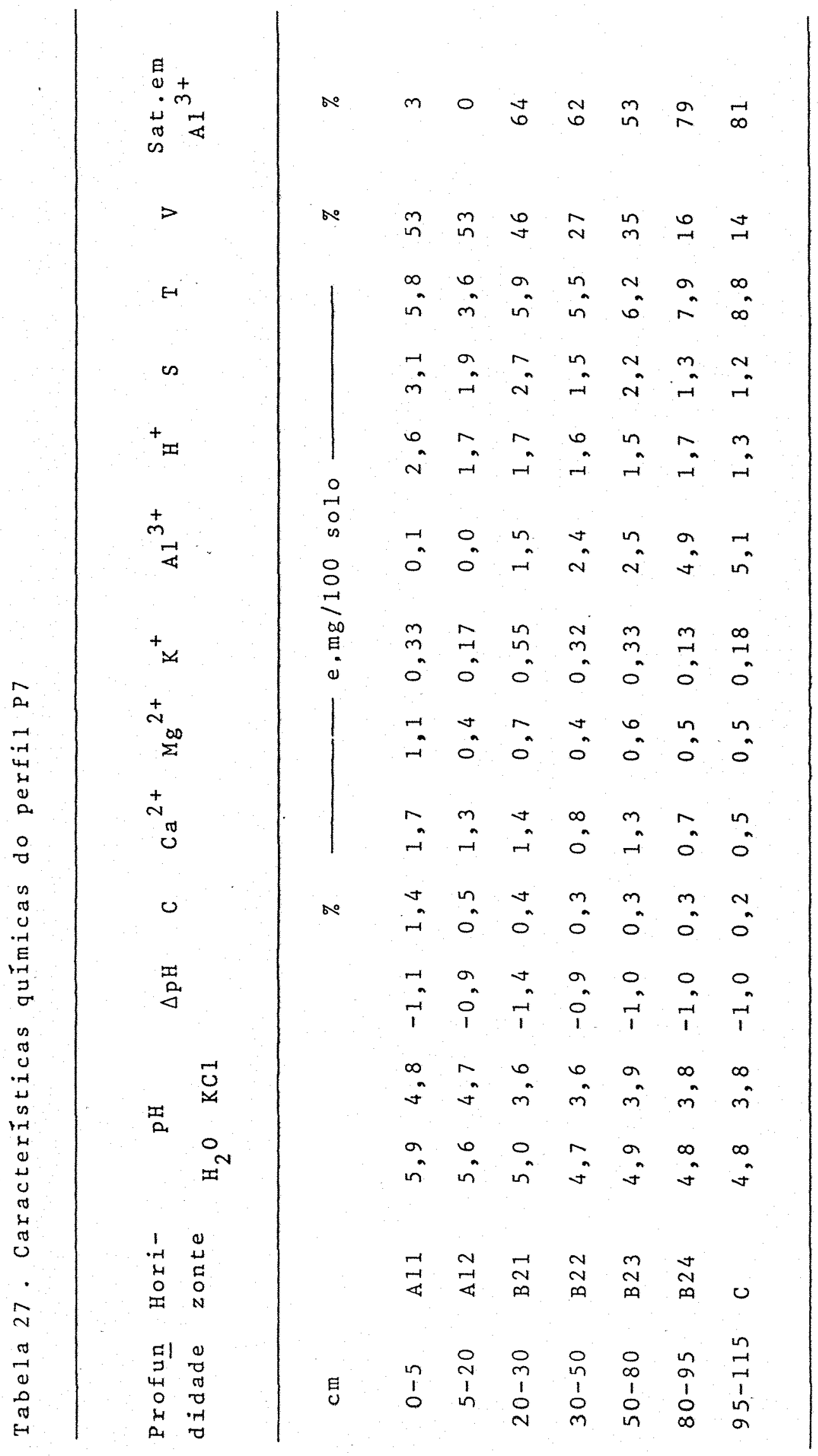




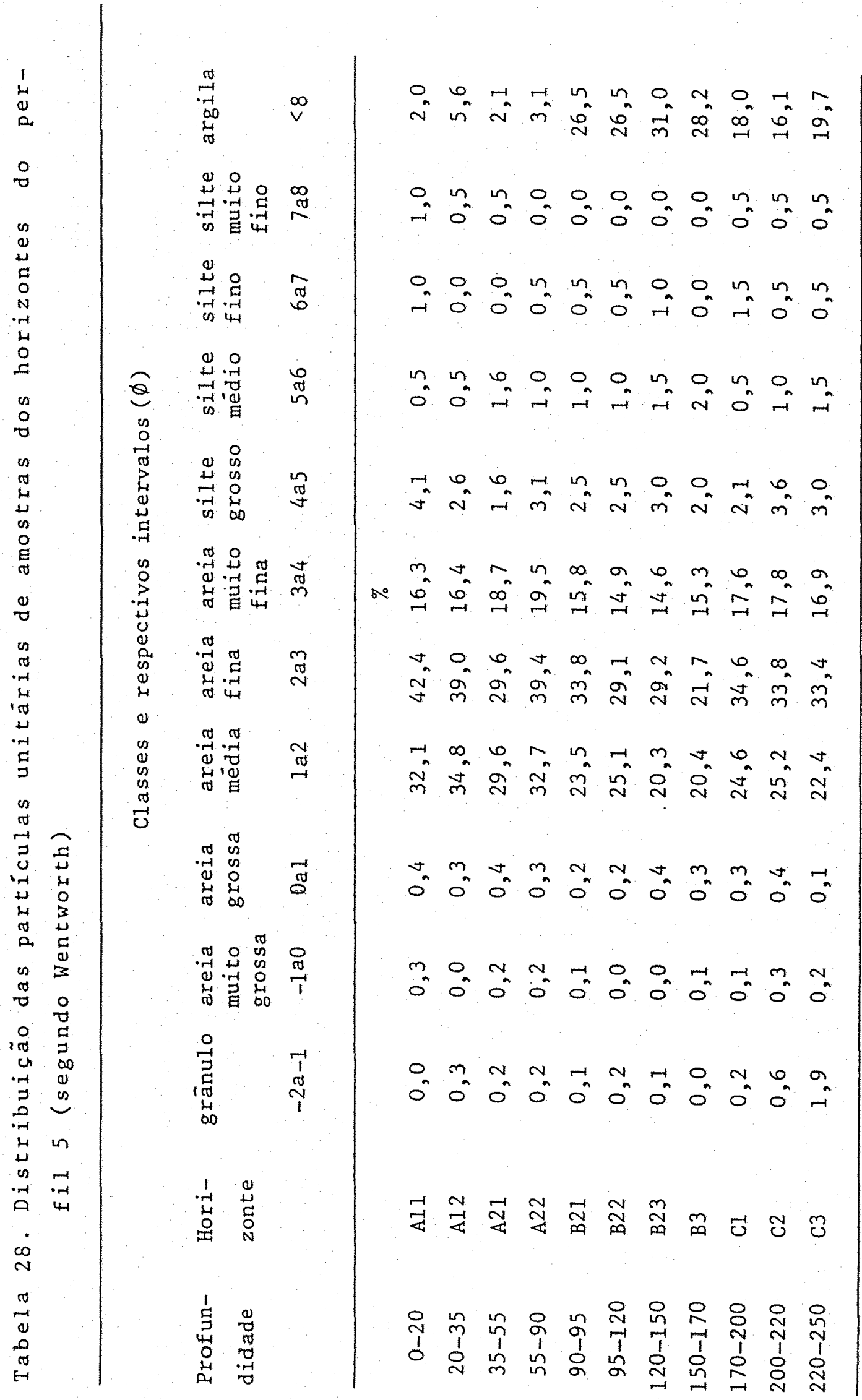




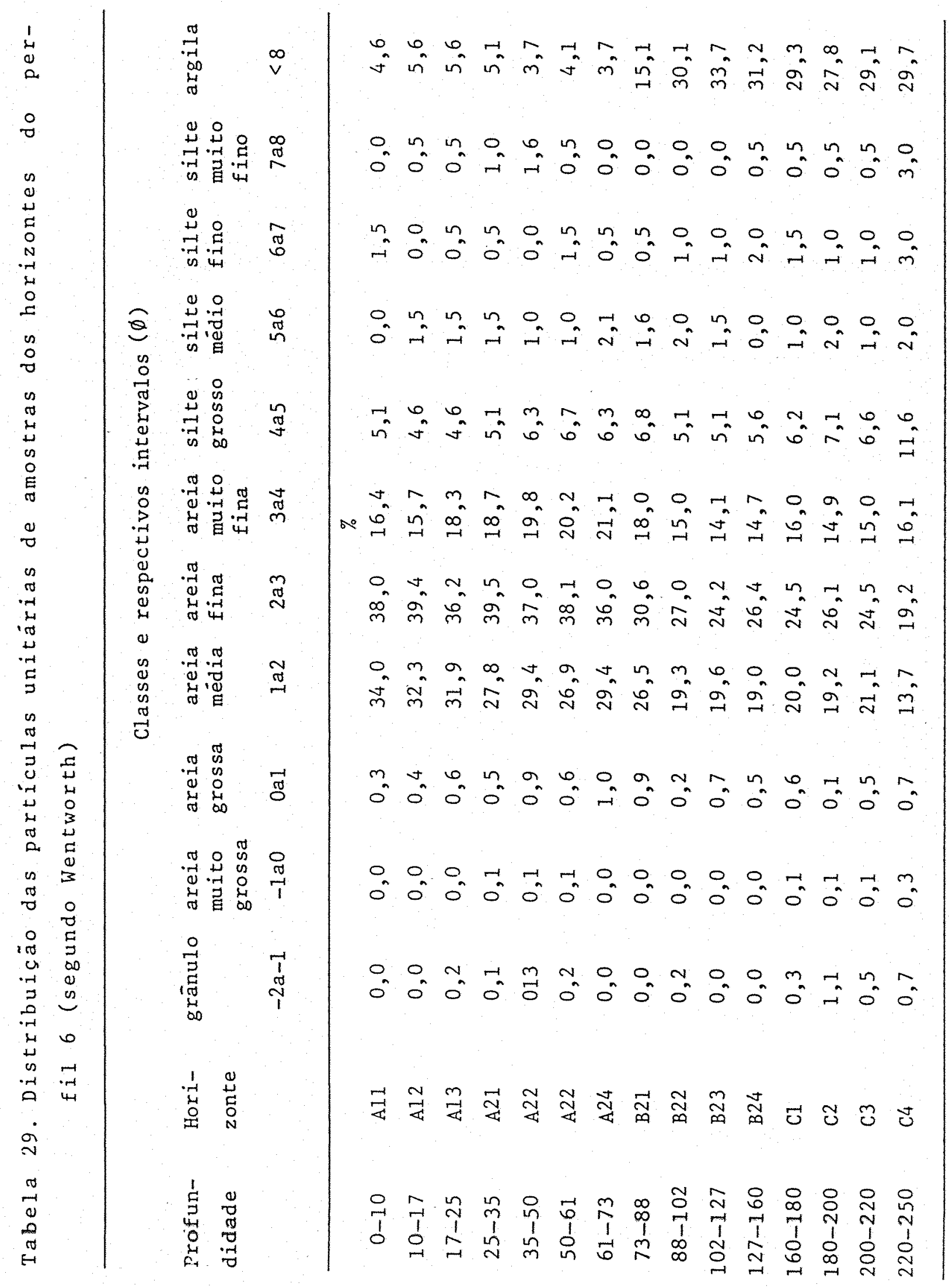




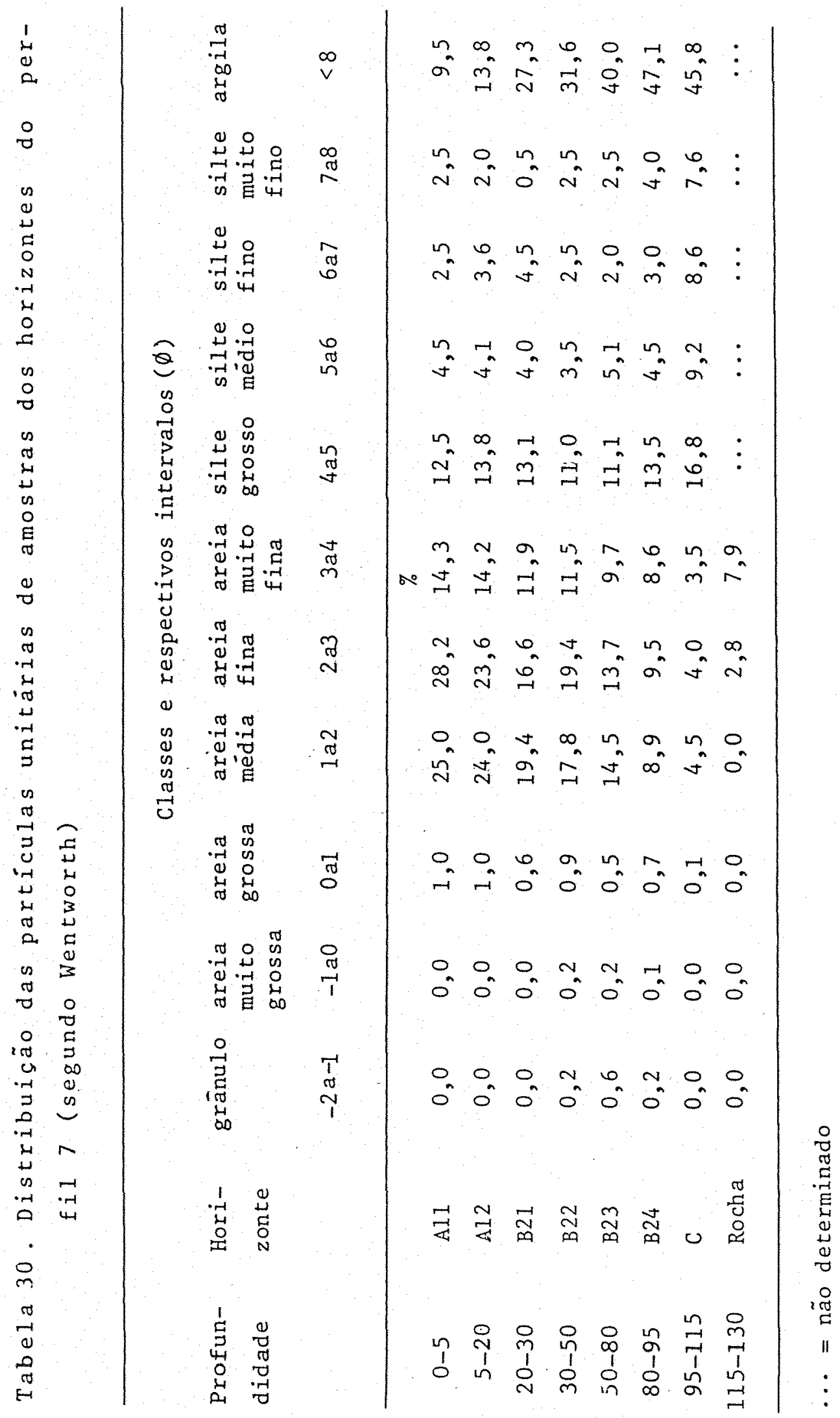




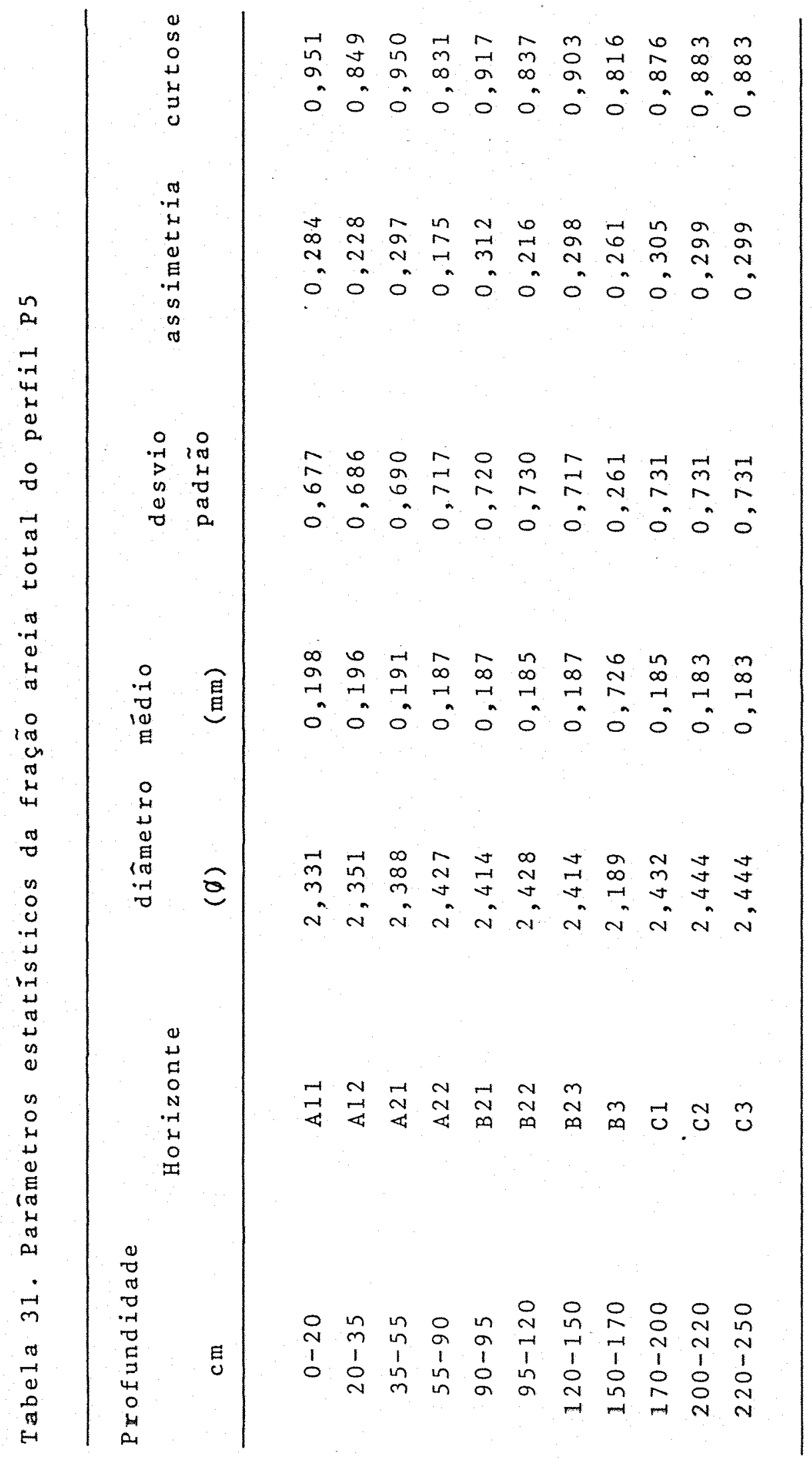




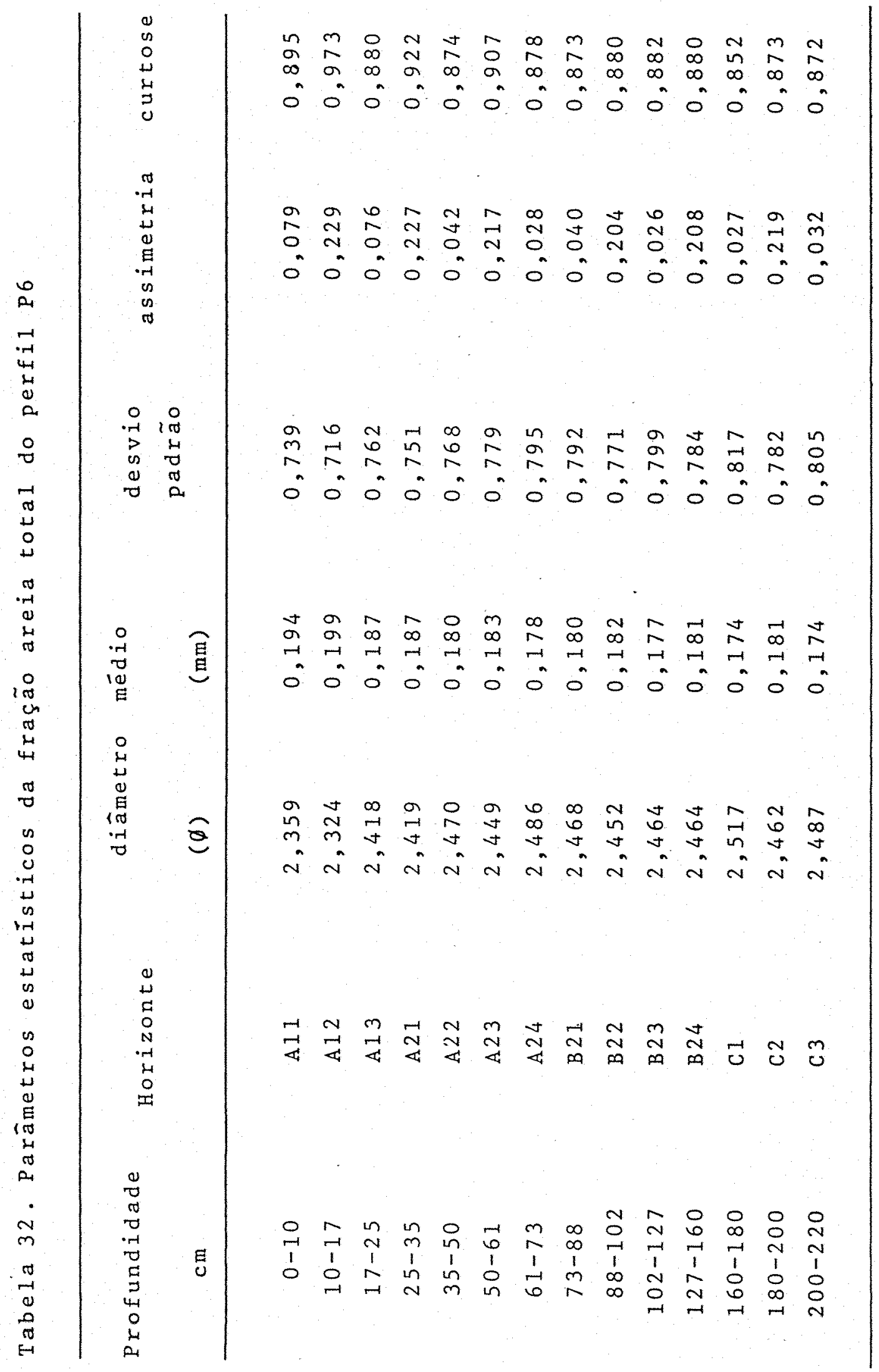




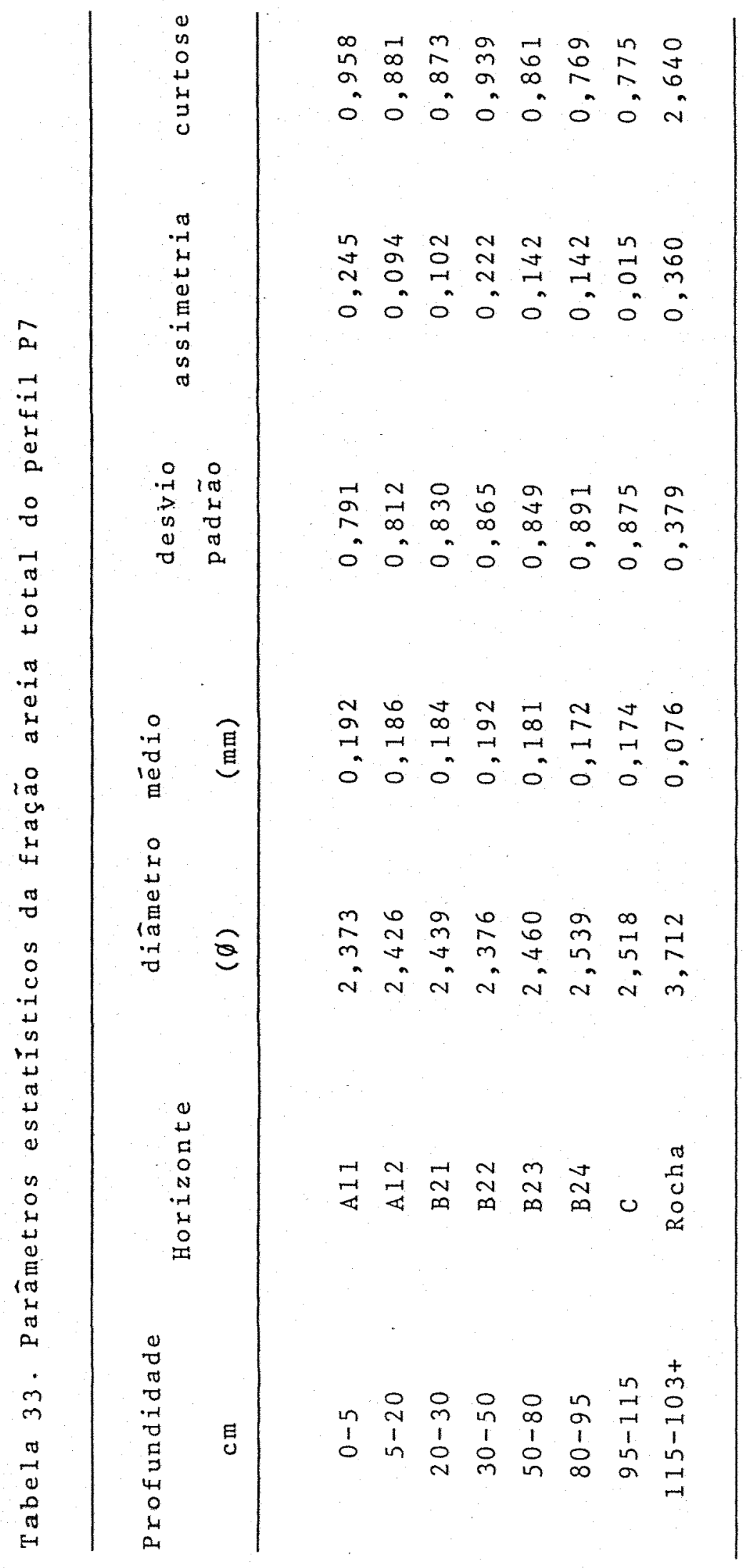


Relação areia fina/areia grossa

os valores da relação areia fina / areia grossa do perfil P7 variam muito em profundidade (Tabela 34) passando de 1,3 no horizonte A11 para 5,6 no horizonte $C$, e sugerem a ocorrência de estratos coluvionais que foram sucessivamente de positados entre os horizontes B23, B24 e C. 


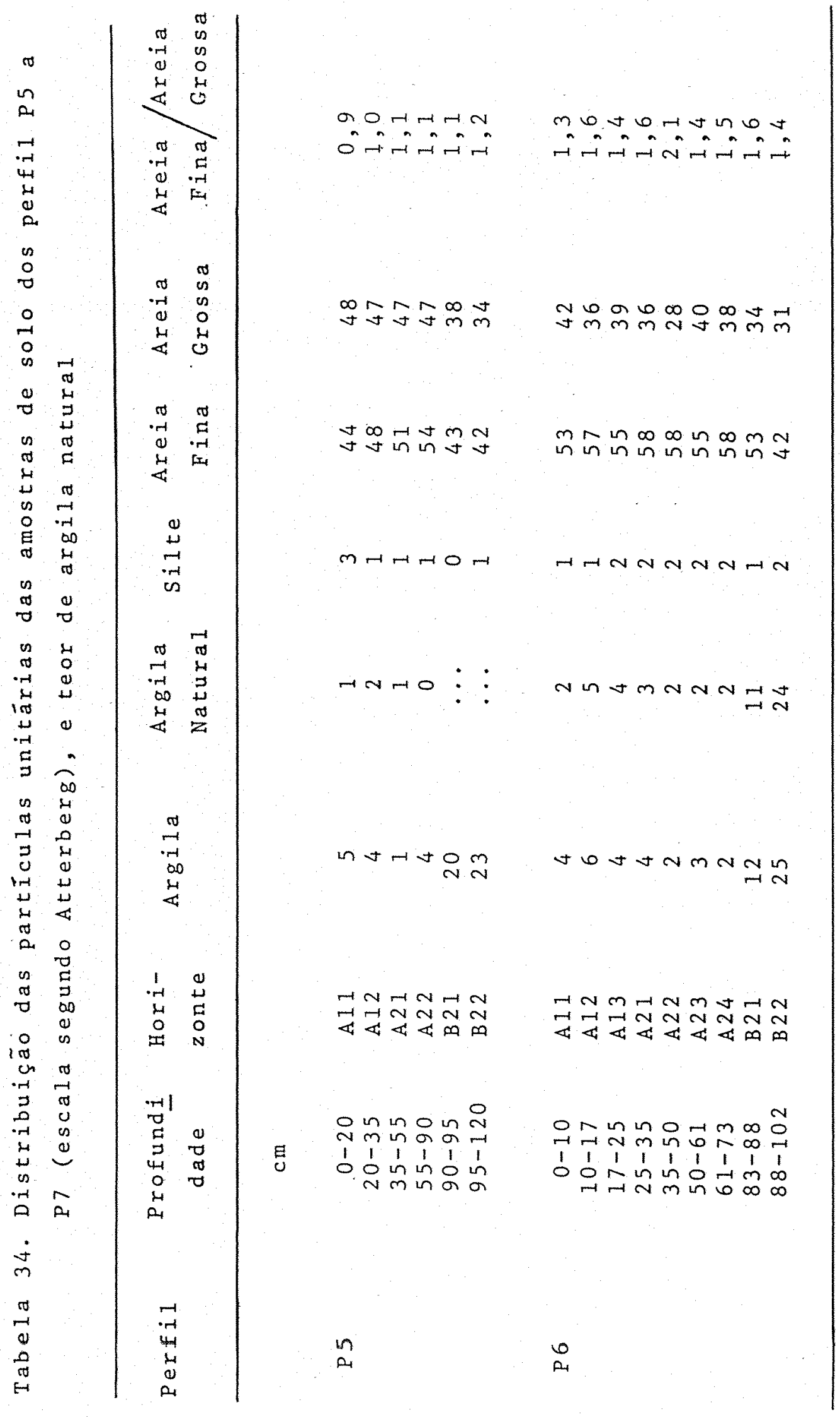




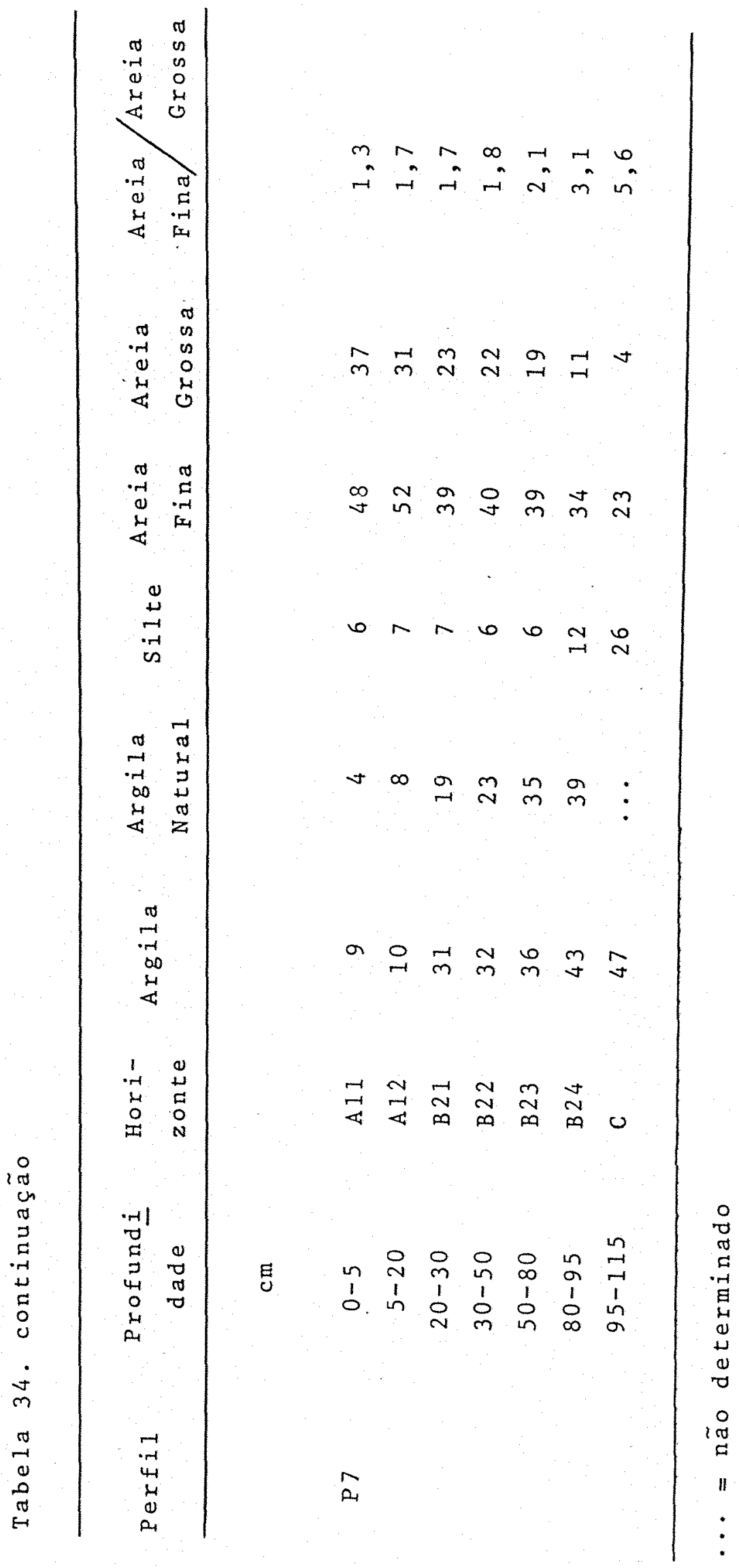




\subsubsection{Anä1ise de morfoscopia}

Nos perfis P5 a P7, os valores de arredondamento mëdio no horizonte $\Lambda 1$ são, respectivamente, $0,59,0,63$ e 0,61 , no horizonte B $0,57,0,60$ e 0,54 e no horizonte C 0,42 , 0,53 e 0,51 . No perfil P7 foi estudado o arredondamento da areia da rocha (folhelho) tendo-se encontrado para esse material o valor médio de 0,35. Portanto tem-se nessa rocha areia bem menos arredondada do que no solo suprajacente. o valor de arredondamento médio do horizonte $A(0,61)$ è mais alto do que - encontrado para o horizonte B $(0,54)$, que está próximo do va lor relativo ao horizonte $C(0,51)$, indicando que no horizonte A tem-se areia mais retrabalhada (Tabela 35 ).

Tabela 35. Valores de arredondamento médio dos horizontes A, B e C e da rocha dos perfis P5 a P7 (encosta B):

Horizonte

PERFIL.

P 5

P 6

P 7

A1 1

0,59

0,63

0,61

A 12

0,63

0,59

0,61

B 2

0,57

0,60

0,54

C

0,42

0,53

0,51 
83

A figura 8 apresenta histogramas das classes de arredondamento da fração areia muito fina $(0,125-0,062 \mathrm{~mm})$ dos três perfis da encosta B. Essa figura mostra que para o PVp (perfil P7), nos horizontes $A$ e $B$, é mais elevada a frequência de valores mais altos de arredondamento da f́ração areia do que no horizonte $C$, e principalmente do que na rocha (folhe 1ho). 

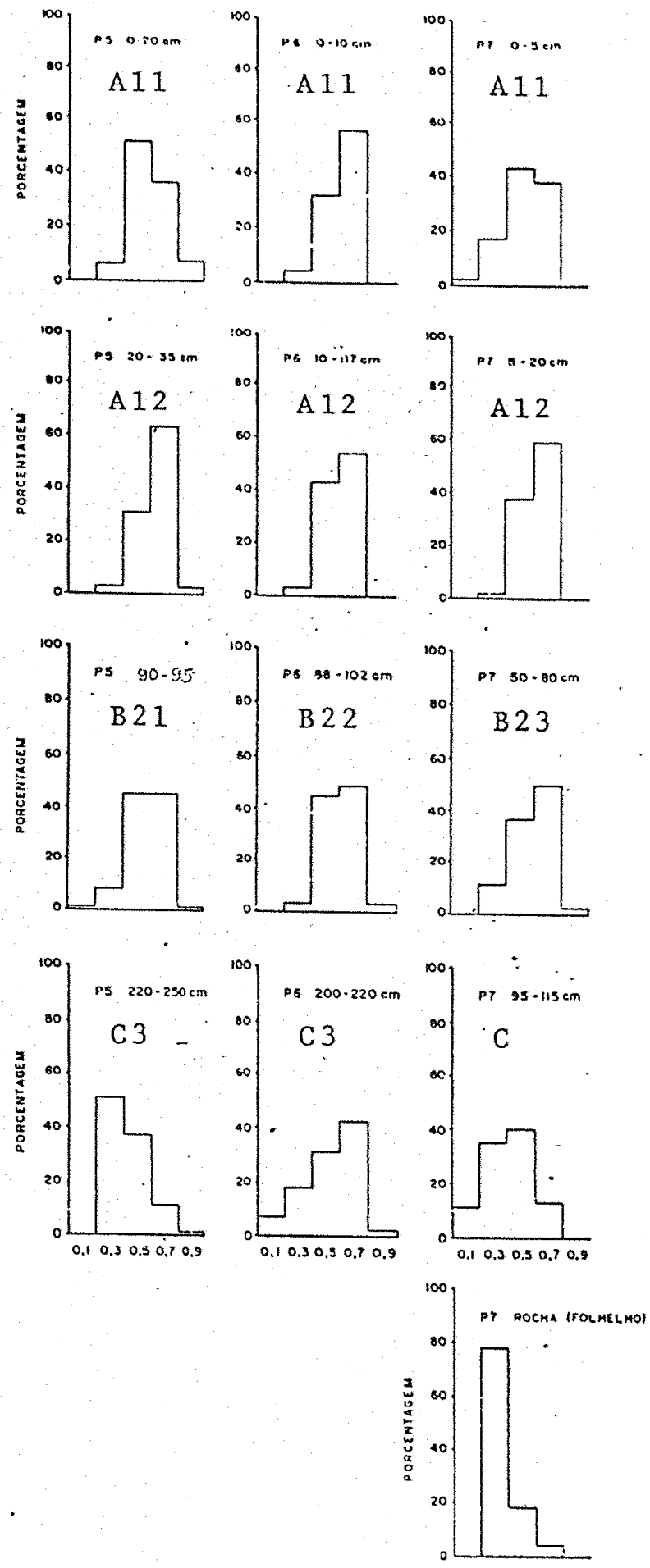

Figura 8. Histogramas da distribuição de classes de arredondamento da fração areia muito fina dos horizontes A, B e C e/ou da rocha dos perfis P5 a P7. 
5.2.6. Estudo dos minerais pesados

os minerais pesados da fração areia muito íina $(0,125-0,062 \mathrm{~mm})$ dos horizontes $A, B$ e C dos três perfis da en costa B são dos mesmos tipos identificados nos perfis da encos ta A (zircão, turmalina, estaurolita e rutilo), exceto a ciani ta que não foi encontrada (Tabela 36 ).

Tabela 36. Frequências porcentuais dos minerais pesados transparentes referentes aos perfis de solos da encosta B. (fração $0,125-0,062 \mathrm{~mm}$ ).

\begin{tabular}{|c|c|c|c|c|c|c|c|}
\hline Perfil & $\begin{array}{l}\text { Profun } \\
\text { didade }\end{array}$ & $\begin{array}{l}\text { Hori- } \\
\text { zonte }\end{array}$ & Rutilo & $\begin{array}{c}\text { Estauro } \\
\text { lita }\end{array}$ & $\begin{array}{c}\text { Zircão } \\
\text { (z) }\end{array}$ & $\begin{array}{c}\text { Turma } \\
\text { Iina } \\
\text { (T) }\end{array}$ & $Z / I$ \\
\hline & $\mathrm{cm}$ & . & & & & & \\
\hline \multirow[t]{3}{*}{ P 5} & $0-20$ & A 11 & 1 & 8 & 52 & 39 & 1,3 \\
\hline & $20-35$ & A 12 . & 6 & 1 & 75 & 18 & 4,2 \\
\hline & $90-95$ & B 21 & 0 & 11 & 19 & 70 & 0,3 \\
\hline \multirow[t]{4}{*}{ P 6} & $0-10$ & A 11 & -3 & 1 & 67 & 29 & 2,3 \\
\hline & $10-17$ & A 12 & 5 & 1 & 73 & 21 & 3,5 \\
\hline & $61-73$ & A 24 & 1 & 5 & 68 & 26 & 2,6 \\
\hline & $73-88$ & B 21 . & 0 & 6 & 74 & 20 & 3,7 \\
\hline \multirow[t]{4}{*}{ P 7} & $0-5$ & A 11 & 4 & 2 & 71 & 23 & 3,1 \\
\hline & $5-20$ & A 12 & 0 & 4 & 84 & 12 & 7,0 \\
\hline & $50-80$ & B 13 & 0 & 1 & 75 & 24 & 3,1 \\
\hline & $80-95$ & B 24 & 2 & 4 & 76 & 18 & 4,2 \\
\hline
\end{tabular}


86

Relação Zircão/Turmalina ( $/ T$ )

os valores $Z / T$ do perfil P7 (PVp) apresentam va riações não sö entre os horizontes A e B, mas também no horizonte B (Tabela 36). Portanto a mesma interpretação verificada para o perfil P4 da encosta A, pode ser feita para o perfil P7 da encosta B, ou seja essas variações obtidas nos diferentes horizontes do perfil não necessariamente coincidem com os limi tes entre os horizontes $A$ e $B$, e não justificam o exagerado aumento de argila entre eles. 


\section{2 .7 . Ferro}

Nos perfis P5, P6 e P7 foram feitas anälises de ferro extraído pelo método do ditionito. o perfil p7 por repre sentar o solo que motivou a realização do presente estudo. (PVp) alèm do ferro livre, foram feitas anälises com extrações do fer ro pelos métodos do àcido sulfūrico e oxalato. Com esses dados foram feitas as relações ferro-ditionito/ferro/total (Fe-d 1 Fe-t), ferro oxalato/ferro-ditionito (Fe-ox/Fe-d) e ferro ditionito/argila (Fe-d/argila) (Tabelas 37 e 38 ).

\section{A figura? mostra que as relações Fe-d/Fe-t e} Fe-d/argila são praticamente uniformes ao longo do perfile que a relação Fe-ox/Fe-d diminui em profundidade, passando de 0,7 para 0,3 , indicando melhor cristalizaçäo do ferro no horizonte B . 


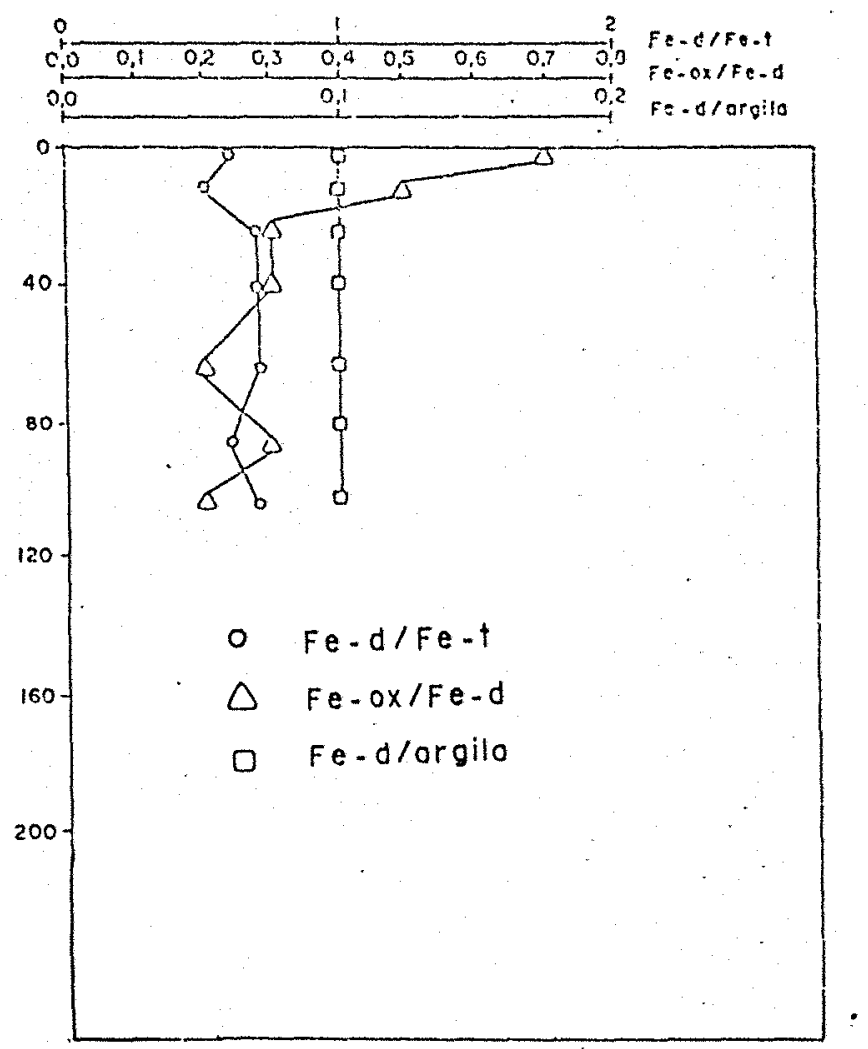

Figura 9. Relações ferro ditionito/ferrototal (Fe-d/Fe-t), ferro-oxalato/ferro ditionito (Fe-ox/Fe-d)e ferro ditionito/argila (Fe-d/argila) do perfil P7. 
Tabela 37 . Ferro extraído pelo método do ditionito (Fe-d), teor de argila e relação Fe-d/argila dos perfis P5 e P6

Perfil Profundi $\underset{\text { dade }}{\text { Horizonte Fe-d Argila Fe-d/argila }}$

\begin{tabular}{|c|c|c|c|c|c|}
\hline & $\mathrm{cm}$ & & $\%$ & $\%$ & \\
\hline \multirow[t]{9}{*}{ P 5} & $0-20$ & A 11 & 0,33 & 5 & 0,07 \\
\hline & $20-35$ & $\mathrm{~A} 12$ & 0,25 & 4 & 0,06 \\
\hline & $35-55$ & A 21 & 0,15 & 1 & 0,15 \\
\hline & $55-90$ & A 22 & 0,17 & 1 & 0,17 \\
\hline & $90-95$ & B 21 & 0,68 & 20 & 0,03 \\
\hline & $95-120$ & B 22 & 0,66 & 23 & 0,03 \\
\hline & $120-150$ & B 23 & 0,66 & 29 & 0,02 \\
\hline & $150-170$ & B 3 & 0,58 & 26 & 0,02 \\
\hline & $170-200$ & $\mathrm{C}$ & 0,68 & 16 & 0,04 \\
\hline \multirow[t]{13}{*}{ P 6} & $0-10$ & A 11 & 0,26 & 4 & 0,07 \\
\hline & $10-17$ & A 12 & 0,30 & 4 & 0,06 \\
\hline & $17-25$ & A 13 & 0,30 & 4 & 0,08 \\
\hline & $25-35$ & A 21 & 0,24 & 4. & 0,06 \\
\hline & $35-50$ & A 22 & 0,13 & 2 & 0,07 \\
\hline & $50-61$ & A 23 & 0,21 & 3 & 0,07 \\
\hline & $61-73$ & A 24 & 0,17 & 2 & 0,09 \\
\hline & $73-88$ & B 21 & 0,70 & 12 & 0,06 \\
\hline & $88-102$ & B 22 & 0,89 & 25 & 0,04 \\
\hline & $102-127$ & B 23 & 1,04 & 31 & 0,03 \\
\hline & $127-160$ & B 3 & 1,04 & 27 & 0,04 \\
\hline & $160-180$ & CI & 1,01 & 26 & 0,04 \\
\hline & $180-200$ & $\mathrm{C} 2$ & 1,07 & 26 & 0,04 \\
\hline & $200-220$ & C 3 & 1,11 & 25 & 0,04 \\
\hline
\end{tabular}




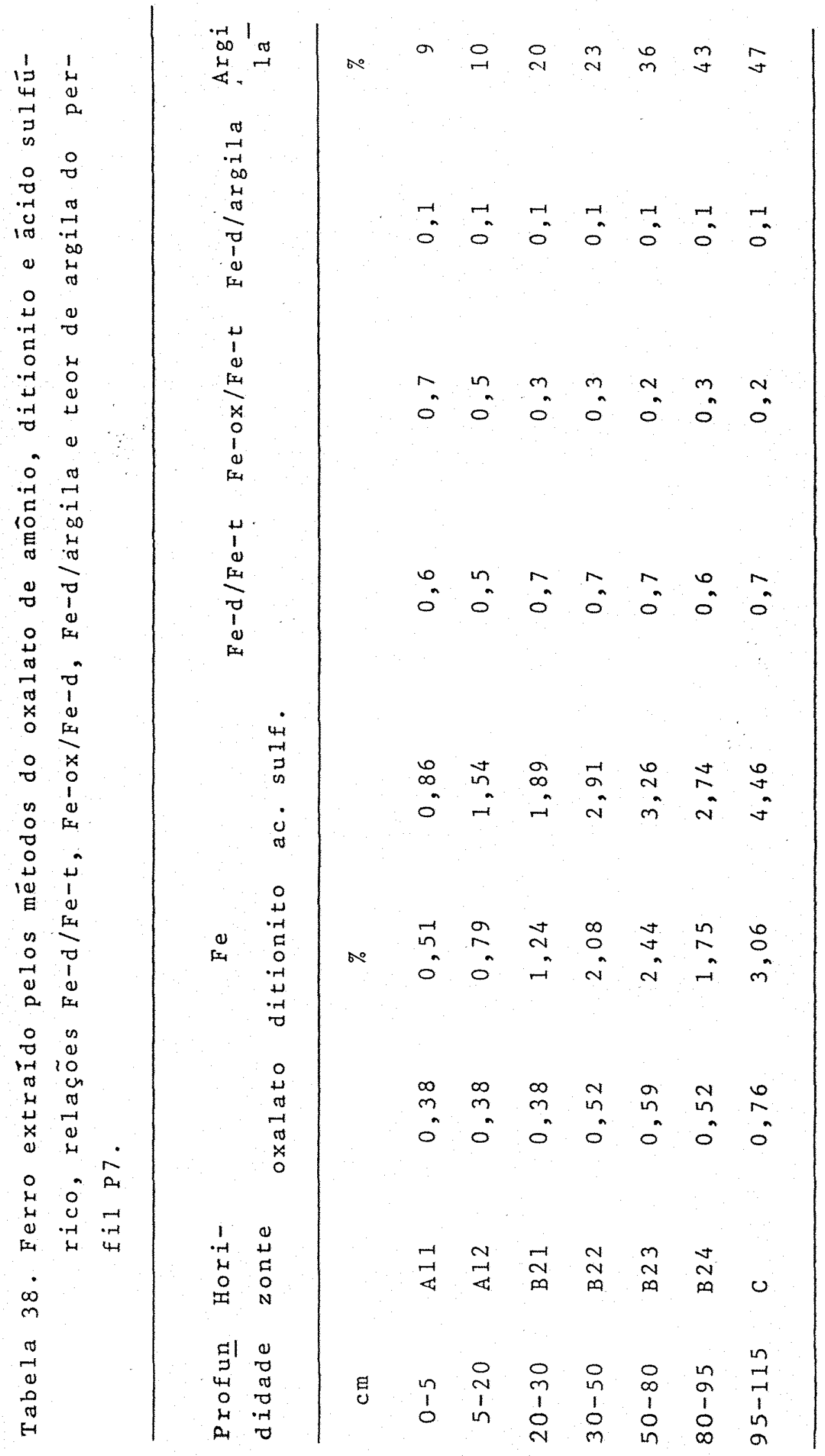


5.2.8. Anālise micromorfológica

Esse estudo foi feito com o objetivo de se conhecer as características micromorfológicas do pVp, e o perfil P7 foi escolhido para esse estudo. Os dados micromorfológicos sumārios desse perfil constam da tabela 39 e referem-seàs amos tras da rocha (folhelho) e dos horizontes sobrejacentes.

Tabela 39. Características micromorfológicas do perfil P7

\begin{tabular}{|c|c|c|c|c|c|c|}
\hline \multirow[b]{2}{*}{$\begin{array}{l}\text { Profun } \\
\text { didade }\end{array}$} & \multirow[b]{2}{*}{$\begin{array}{l}\text { Hori- } \\
\text { zonte }\end{array}$} & \multirow[b]{2}{*}{$\begin{array}{l}\text { Grãos E } \\
\text { queleto }\end{array}$} & \multicolumn{3}{|c|}{ CARACTERISTICAS } & \\
\hline & & & Vazio & P 1 a sma & $\begin{array}{l}\text { Argila or } \\
\text { cutans de } \\
\text { iluviação }\end{array}$ & $\begin{array}{l}\text { ientada } \\
\text { papulas }\end{array}$ \\
\hline $\mathrm{cm}$ & & & & $\%$ & & \\
\hline $0-5$ & A 11 & 60 & 39 & 1 & 0 & 0 \\
\hline $5-20$ & A 12 & 55 & 44 & 1 & 0 & 0 \\
\hline $20-30$ & B 21 & 45 & 44 & 10 & 1 & 0 \\
\hline $30-50$ & B 22 & 55 & 14 & 30 & 1 & 0 \\
\hline $50-80$ & B23 & $5 ?$ & 18 & 30 & 1 & 0 \\
\hline $80-95$ & B 24 & 50 & 20 & 28 & 2 & 0 \\
\hline $95-105$ & B 3 & 25 & 35 & 40 & 0 & 0 \\
\hline $105-115$ & C & 98 & 2 & 0 & 0 & 0 \\
\hline
\end{tabular}

As figuras 10 a 14 apresentam as caracteristicas micromorfologicag da rocha (10lhelho) e dos principais ho- 
rizontes do perfil P7.

o processo pedogenético mais significativo do PVp è a translocação de argila, evidenciada pela presença de argillans de iluviação no horizonte B2 (Figura 12). A presença de argillans de iluviação no horizonte B nem sempre é facilmen te diagnosticada, pois pode ocorrer sua destruição na massa do solo, como foi verificado por NETTLETON (1969).

McKEAGUE et a1ii (1978) observaram que muitos horizontes considerados no campo como Bt, na realidadenão apre sentaram $1 \%$ de argila de iluviação. Isso não ocorreu no presen te estudo, pois as observaçöes micromorfológicas no horizonte B do PVp (perfil P7) indicaram presença de argillans de iluvia ção de até $2 \%$. Essa quantidade atende a exigência para enquadramento como horizonte argílico, segundo a classificação americana (SOIL TAXONOMY, 1975).

Cälculos mostram que dos $40 \%$ de argila do horizonte B23 do perfil P7, 5\% está sob a forma orientada e que mais provavelmente teve origem por processo de iluviação. 


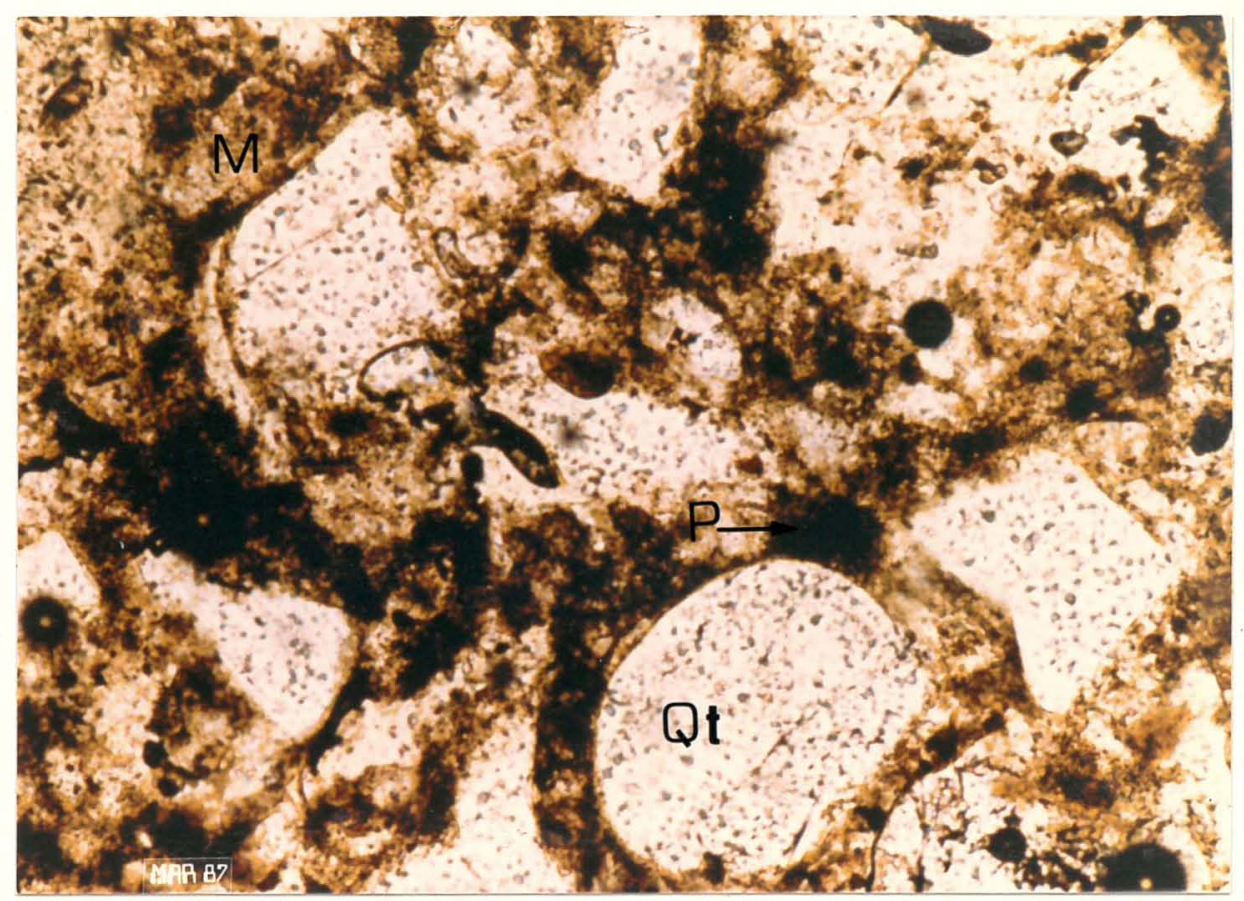

Figura 10. Lâmina delgada do horizonte Al1 fotografada sob microscópio petrográfico com analisador aberto e aumento de $10 x$.

$$
\begin{aligned}
& \mathrm{Qt}=\text { quartzo } \\
& \mathrm{P}=\text { poro } \\
& \mathrm{M}=\text { matrix }
\end{aligned}
$$




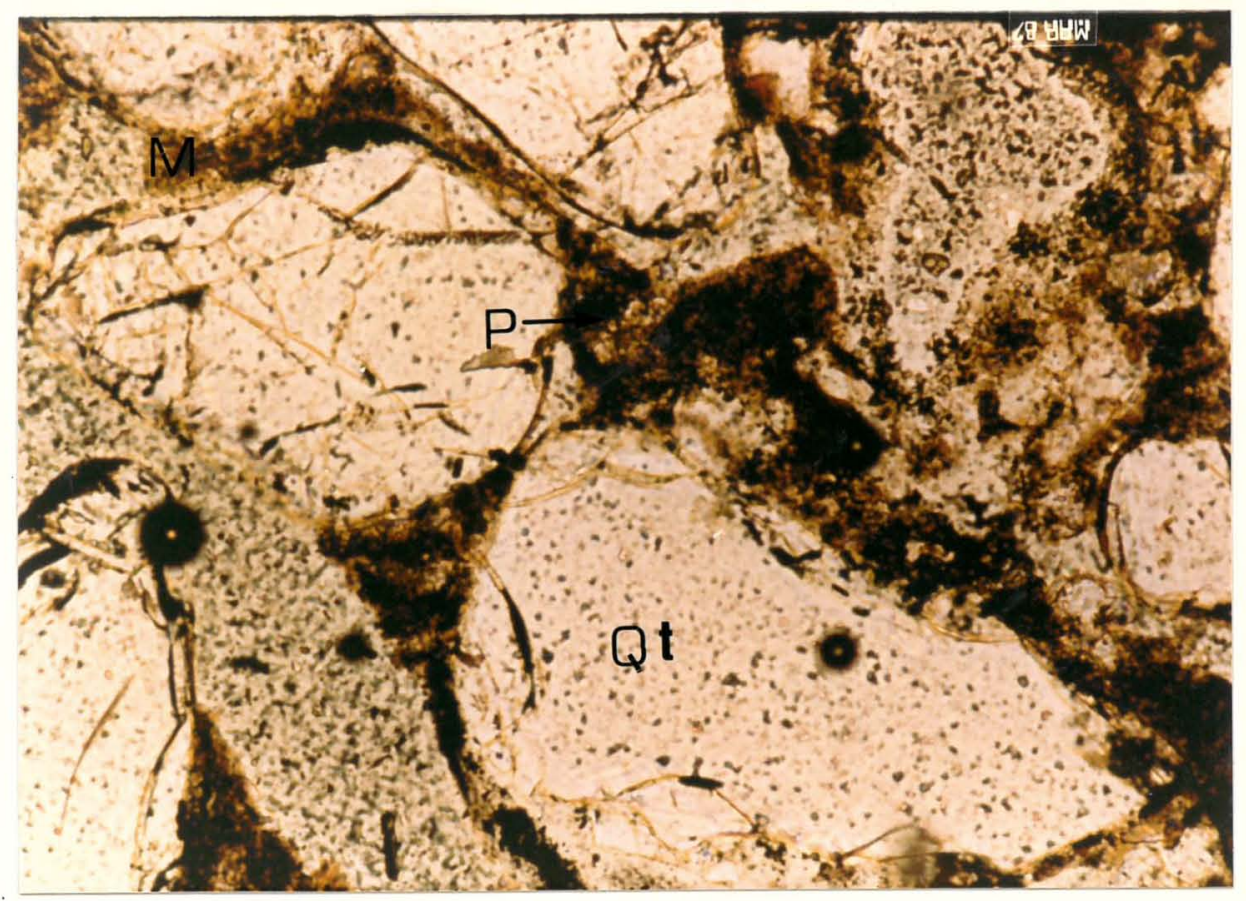

Figura 11. Lâmina delgada do horizonte Al2 fotograf́ada sob microscópio petrogrä́fico com analisador aberto e aumento de $10 x$.

$$
\begin{aligned}
& \mathrm{Qt}=\text { quartzo } \\
& \mathrm{P}=\text { poro } \\
& \mathrm{M}=\text { matrix }
\end{aligned}
$$




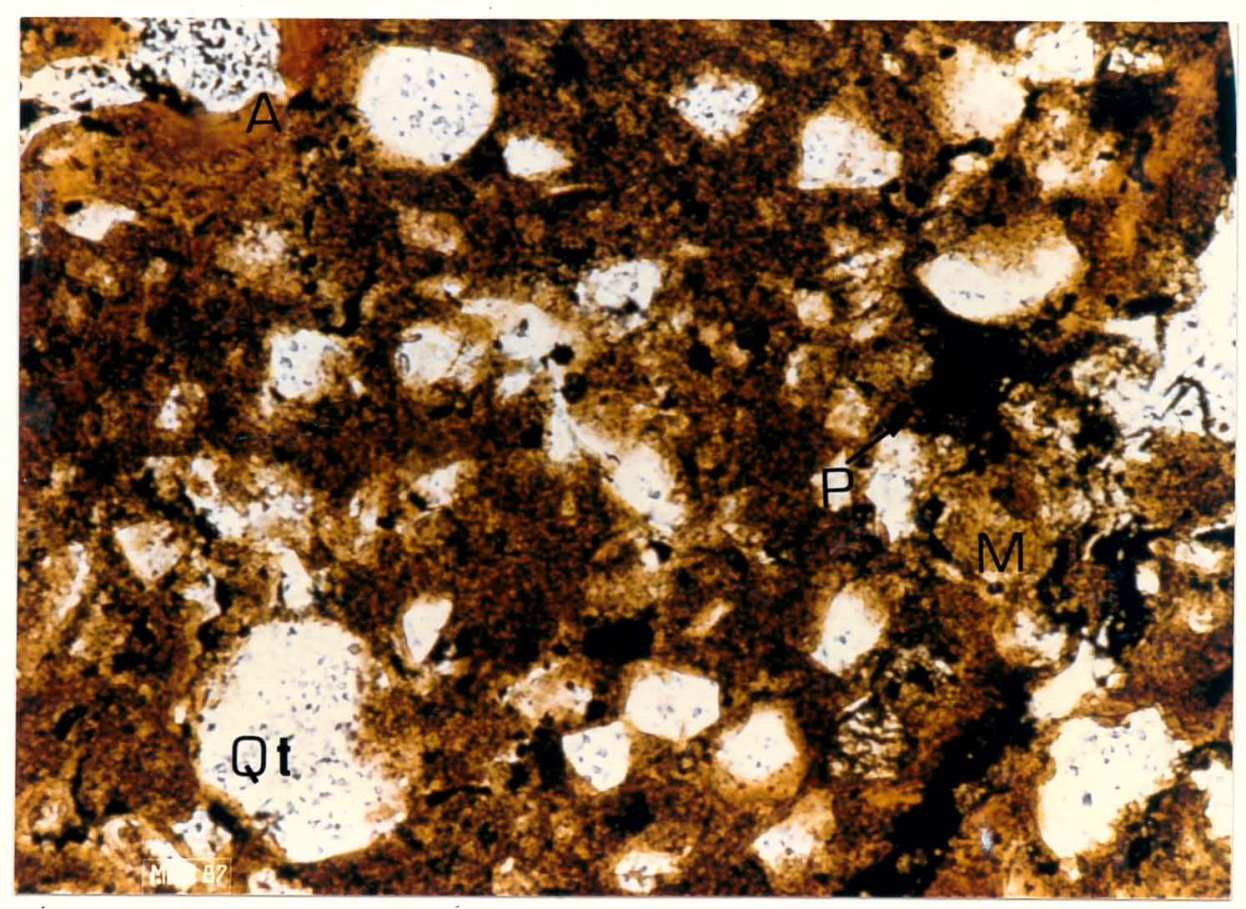

Figura 12. Lâmina delgada do horizonte B21 fotografada sob microscópio petrográfico com analisador aberto e aumento de $10 x$.

$$
\begin{aligned}
\mathrm{Q} t & =\text { quartzo } \\
\mathrm{P} & =\text { poro } \\
\mathrm{M} & =\text { matrix } \\
\mathrm{A} & =\text { Argillans de iluviação de argila }
\end{aligned}
$$




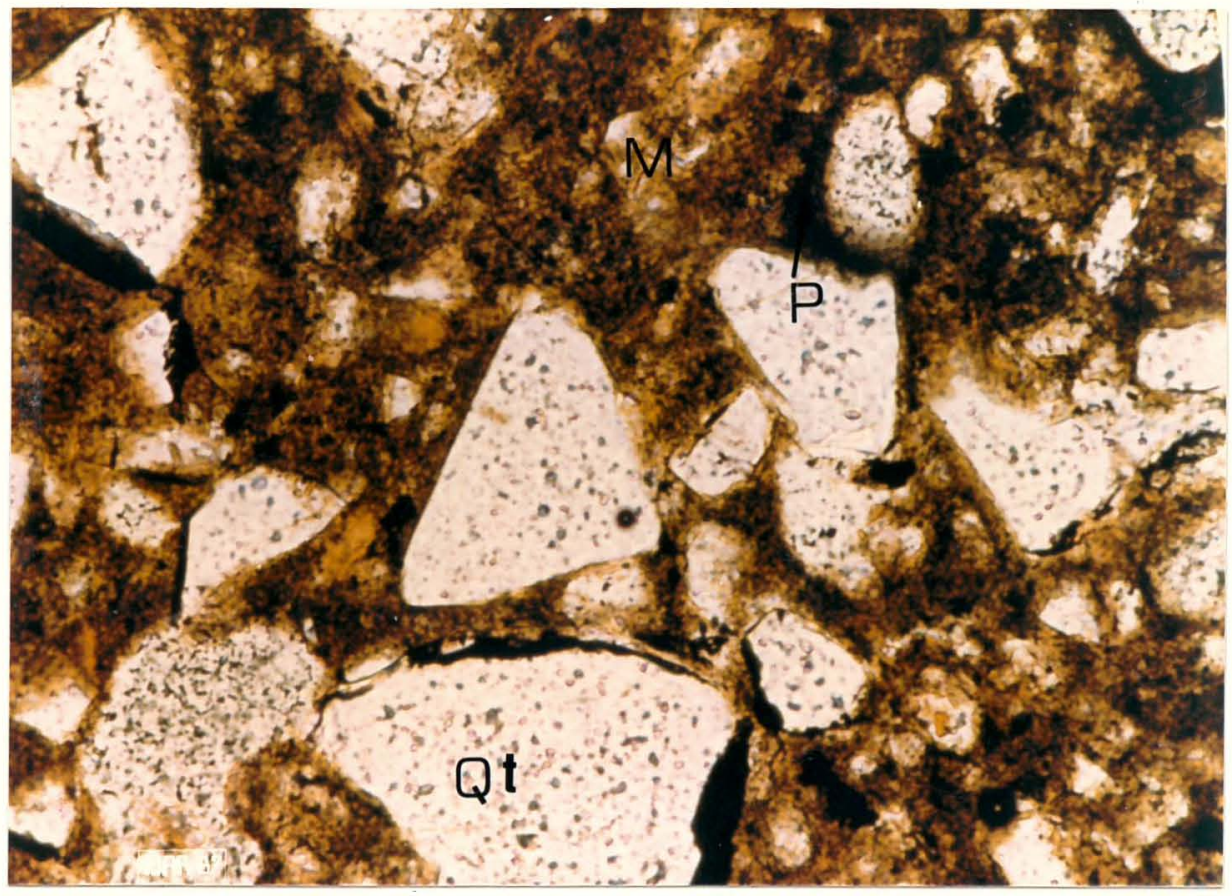

Figura 13. Lâmina delgada do horizonte B3 fotografada sob microscópio petrográfico com analisador aberto e aumento de $10 x$.

$$
\begin{aligned}
Q t & =\text { quartzo } \\
\mathrm{P} & =\text { poro } \\
\mathrm{M} & =\text { matrix }
\end{aligned}
$$




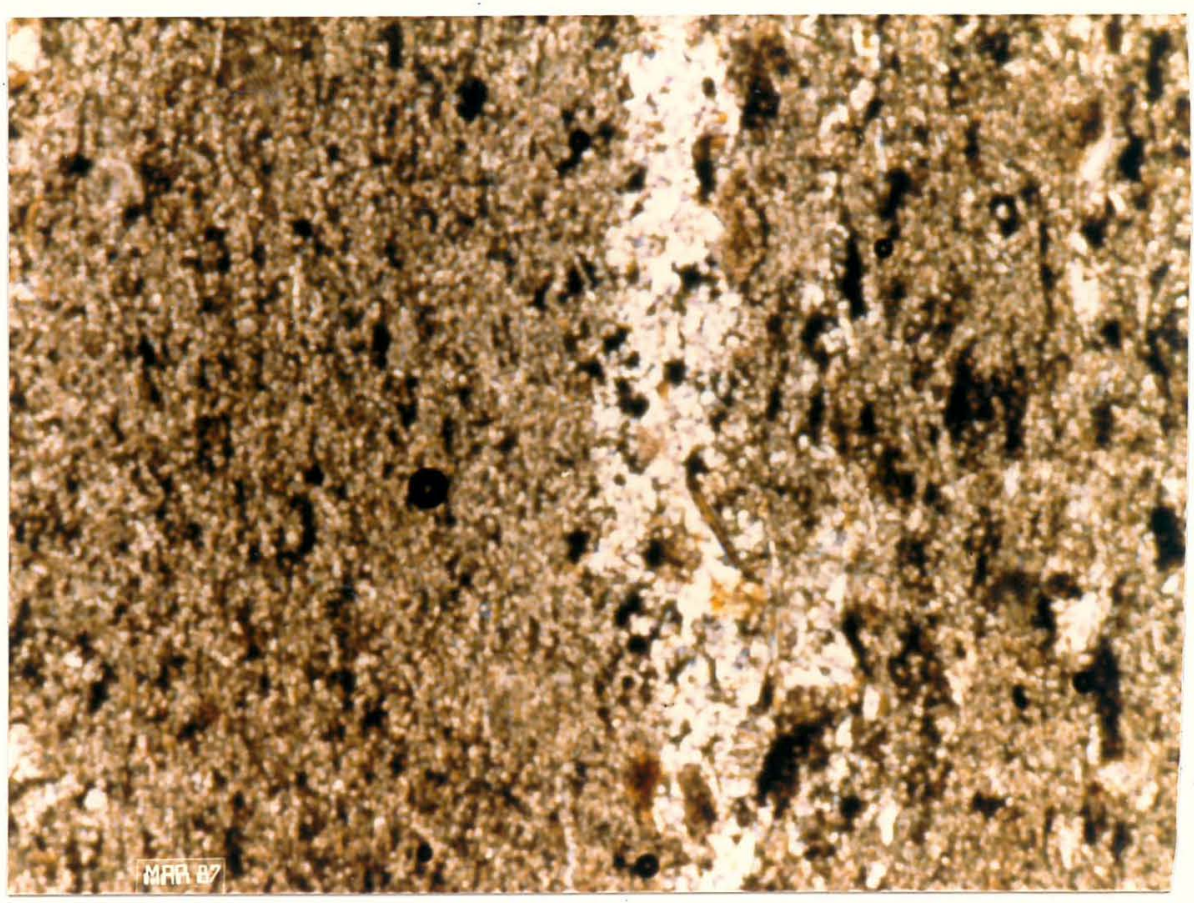

Eigura 14. Lâmina delgada da rocha (folhe1ho) do perfil p7 fotografada sob microscópio petrográfico com analisador aberto e aumento de $10 x$. 
5.2.9. Mineralogia da Fração Argila

A argila foi estudada atraves da difração de raios $x$. As figuras 15 a 17 mostram os difratogramas dos prin cipais horizontes do perfil p7 que foi selecionado para representar o PVp. A caulinita foi identificada pelos espaçamen tos nas regiões de 7,20 a $7,36 \AA$ e 3,55 a $3,59 \AA$ que desapare cem nas amostras saturadas com potássio aquecidas a $550^{\circ} \mathrm{C}$. A mica foi identificada pelo espaçamento nas regiões de 10,0 e $3,32 \AA$, não desaparecendo com nenhum dos tratamentos. Nquart zo foi jdentificado pelo espacamento a 3,32 . A. os minerais in terestratificados foram identificados pelos espaçamentos de picos entre 10 e $14 \AA$

os minerais identificados na fração argila nas amostras selecionadas dos horizontes A1, B21 e C do PVp (perfil P7) são: caulinita, mica, gibbsita e quartzo. Esse resultado concorda parcialmente com o obtido por DECHEN (1979) que estudou o Podzólico Vermelho-Amarelo variação Piracicaba, e encontrou além desses minerais a vermiculita. Comparando os mi nerais do perfil P7 com os obtidos por SOUZA e DEMATTE (1979) verifica-se que esses autores encontraram no Podzólico VermeTho-Amarelo variação Piracicaba montmorilonita e vermiculita alēm de caulinita e gibbsita. 
A partir das evidências dos difratogramas de raios $X$ nos horizontes $A$ e $B$ do perfil P7, onde observa-se pi co indicativo de espaçamento interplanar da mica melhor desen volvido no horizonte A do que no B, foi feita anāilse química total do potásio nas amostras de solo desses horizontes. A porcentagem de mica, determinada atraves do teor total de potássio diminuiu do horizonte $A(1,2 \%)$ para o $B(0,9 \%)$, o que pode ser interpretado tanto como um indício de contribuição de material menos intemperizado na superficie, como pela iluviação preferencial de argila fina, ficando o horizonte A com a concentração residual de argila grossa que, normalmente é mais rica em micadoque a argila fina (LEPSCH e BUOL, 1974) e (LEPSCH et alii, 1978). 


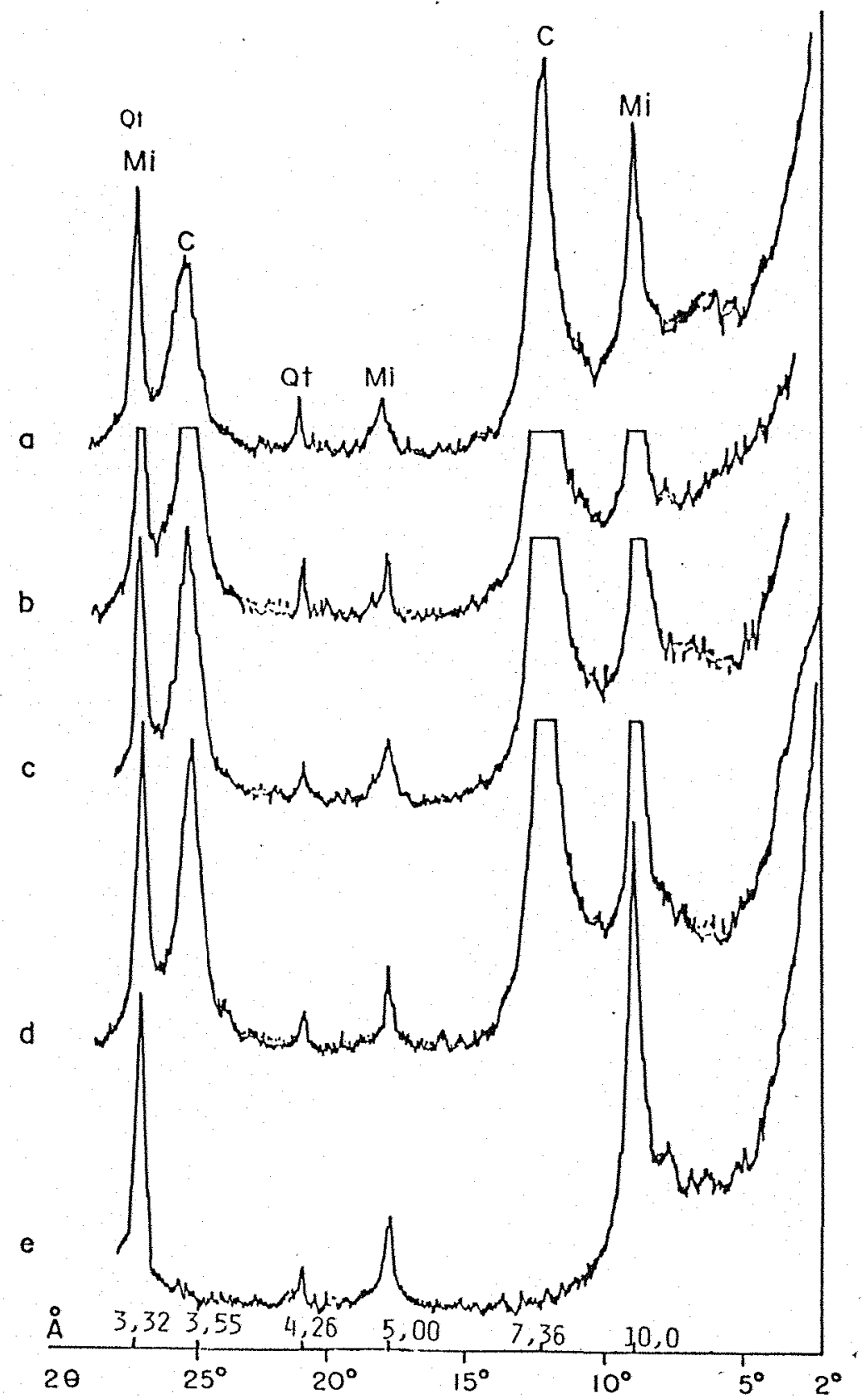

Figura 15. Difratogramas de raios $x$ da frạão argila do horizonte Al do perfil P7 - a: saturada com $\mathrm{Mg}^{2+}$ a tem peratura ambiente; b: glicolada; c: saturada com

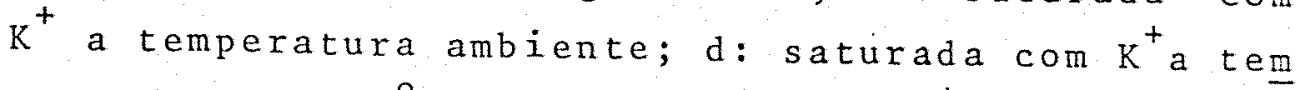
peratura de $350^{\circ} \mathrm{C}$; e: saturada com $\mathrm{K}^{+}$a temperatura de $550^{\circ} \mathrm{C} . \mathrm{C}=$ caulinita; $\mathrm{Mi}=$ mica; $\mathrm{Qt}=$ quartzo. 


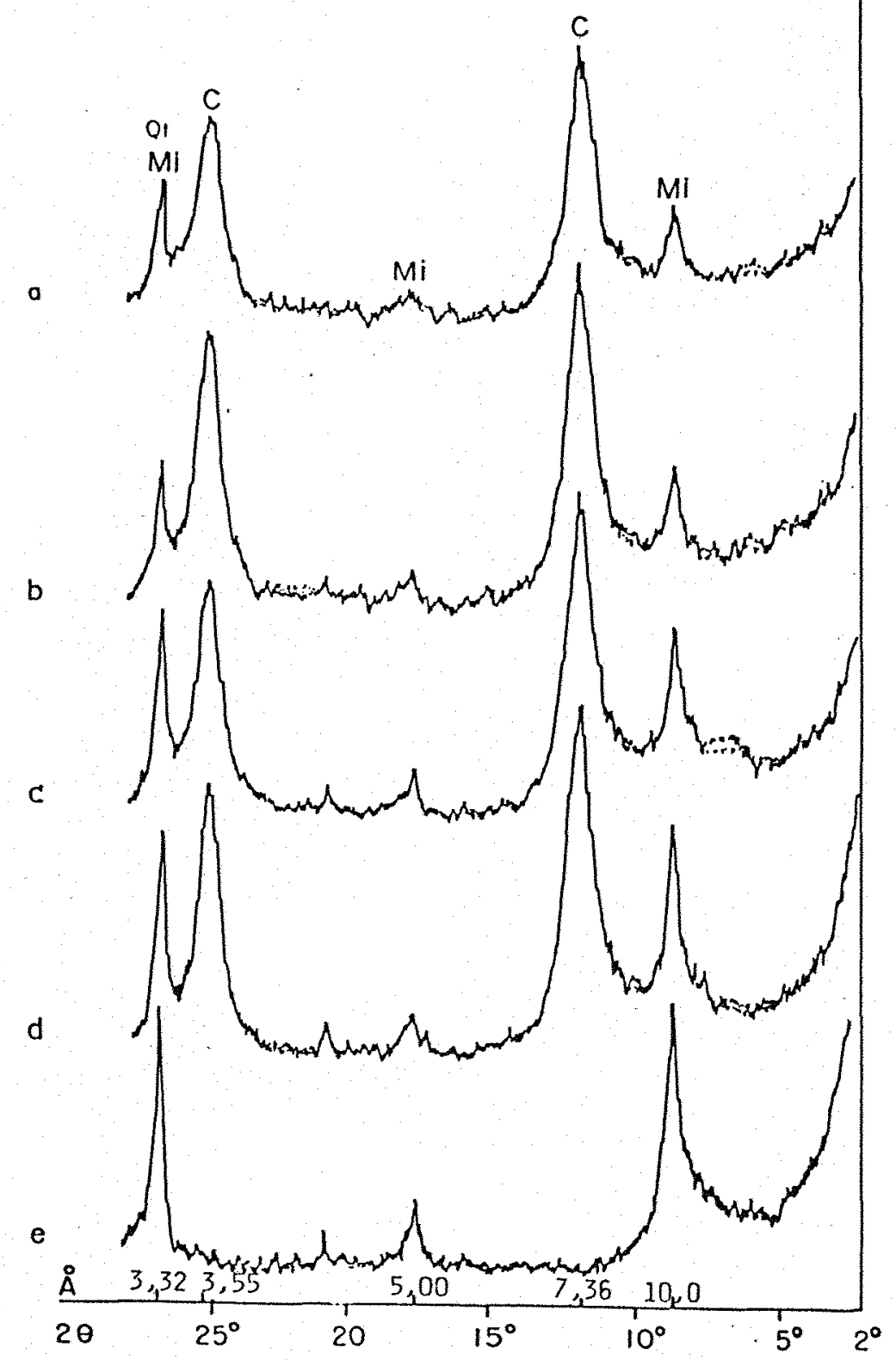

Figura 16. Difratogramas de raios $x$ da fração argila do horizonte B22 do perfil P7 - a: saturada com $\mathrm{Mg}^{2+}$ a tem peratura ambiente; b: glicolada; c: saturada com $\mathrm{K}^{+}$a temperatura ambiente; $\mathrm{d}:$ saturada com $\mathrm{K}^{+} \mathrm{a}$ tem peratura de $350^{\circ} \mathrm{C}$; e: saturada com $\mathrm{K}^{+}$a temperatura de $550^{\circ} \mathrm{C} . \mathrm{C}=$ caulinita; $\mathrm{Mi}=\mathrm{mica}$. 


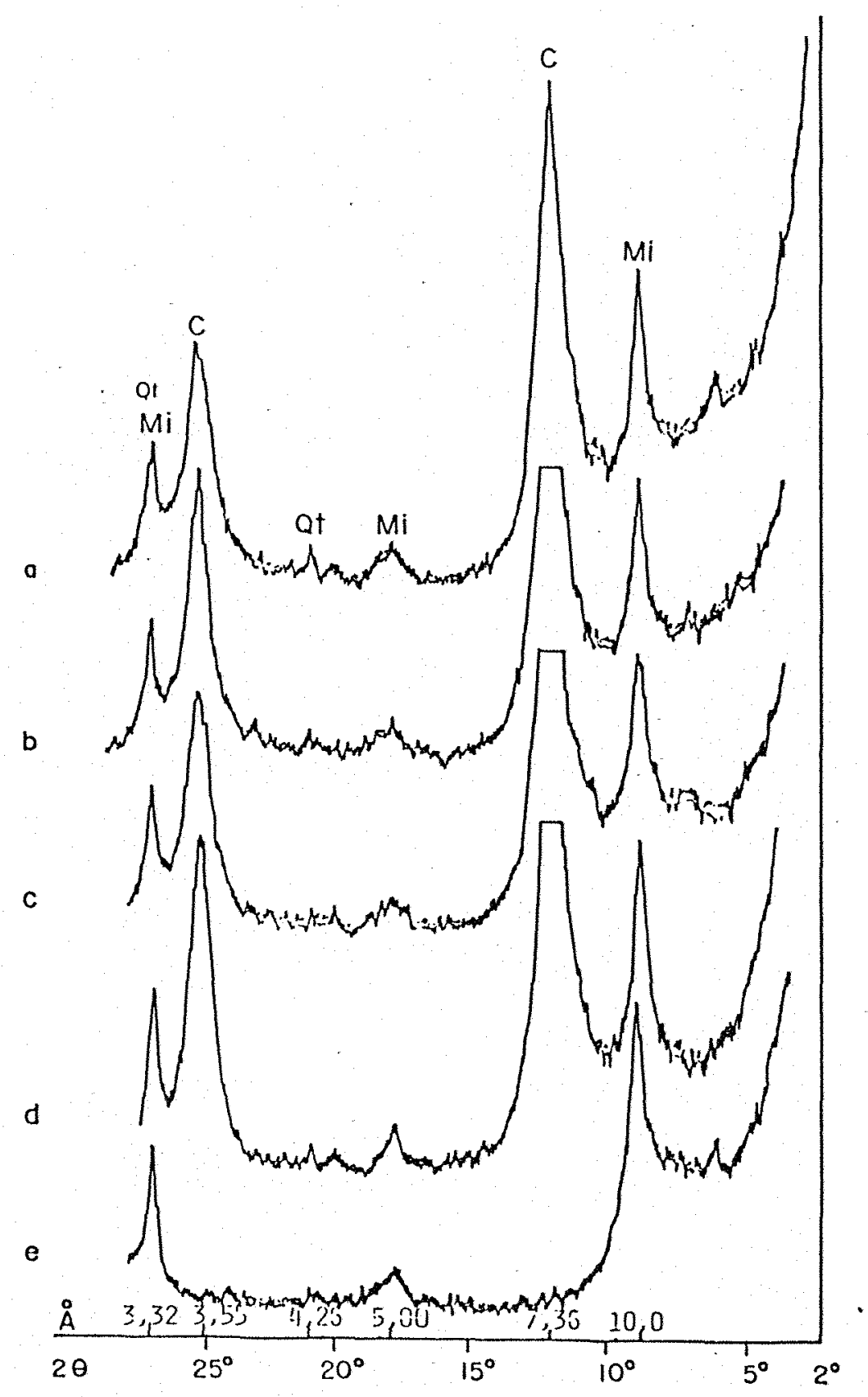

Figura 17. Difratogramas de raios $x$ da fração argila do horizonte C do perfil P7 - a: saturada com $\mathrm{Mg}^{2+}$ a temperatura ambiente; b: glicolada; c: saturada com $\mathrm{K}^{+}$a temperatura ambiente; $\mathrm{d}$ : saturada com $\mathrm{K}^{+}$a tem peratura de $350^{\circ} \mathrm{C}$; e: saturada $\operatorname{com~} \mathrm{K}^{+}$a temperatü ra de $550^{\circ} \mathrm{C} . \mathrm{C}=$ caulinita; $\mathrm{Mi}=\mathrm{mica}, \mathrm{Qt}=$ quart20. 
5.3. Comparação entre o arenito da Formação Pirambóia e o Folhelho da Formação Corumbataí

\subsubsection{Anālise Granulomētrica}

A concentração relativamente grande de areia no horizonte A do PVp (perfis P4 e P7) pode advir tanto de proces sos pedogenéticos, como da migração vertical de argila do hori zonte A para o B, e/ou então pela deposição na superfície proveniente do arenito da Formação Pirambóia e/ou do solo dele de rivado (PV1s), formando um recobrimento mais arenoso superficialmente no PVp que estā na posição mais inferior na encosta do que o PVIs.

Com o objetivo de se conhecer a composição granulometrica do arenito da Formação Piramböia e do folhelho da Formação Corumbatai, foram coletadas amostras desses materiais em äreas adjacentes as encostas $A$ e B. No arenito da Formação Pirambóia o teor de areia varia de 57 a $87 \%$ (Tabela 40 ) e no folhelho da Formação Corumbataí de 2 a $11 \%$ (Tabela 41).

os resultados referentes ao arenito são concordantes com os obtidos por SOARES (1975), que verificou no arenito da Formação Pirambóia composição granulométrica essencial mente arenosa, escassez de clästicos de tamanho inferior a $0,50 \mathrm{~mm}$. e que na fração arenosa predominam as areias muito fina, fina e média.

Segundo o mapa geolögico do Estado de São Paulo 
(IPT, 1981), a Formação Corumbataí na sua parte inferior apresenta siltitos, argilitos e folhelhos e segue-se uma sucessão de camadas siltosas ritmicamente alternadas com lâminas ou de 1 gadas camadas cuja litologia varia entre argilosa e arenosa fi na.

No folhelho os teores de areia muito grossa, grossa e média são nulos ( Tabela 4I). 


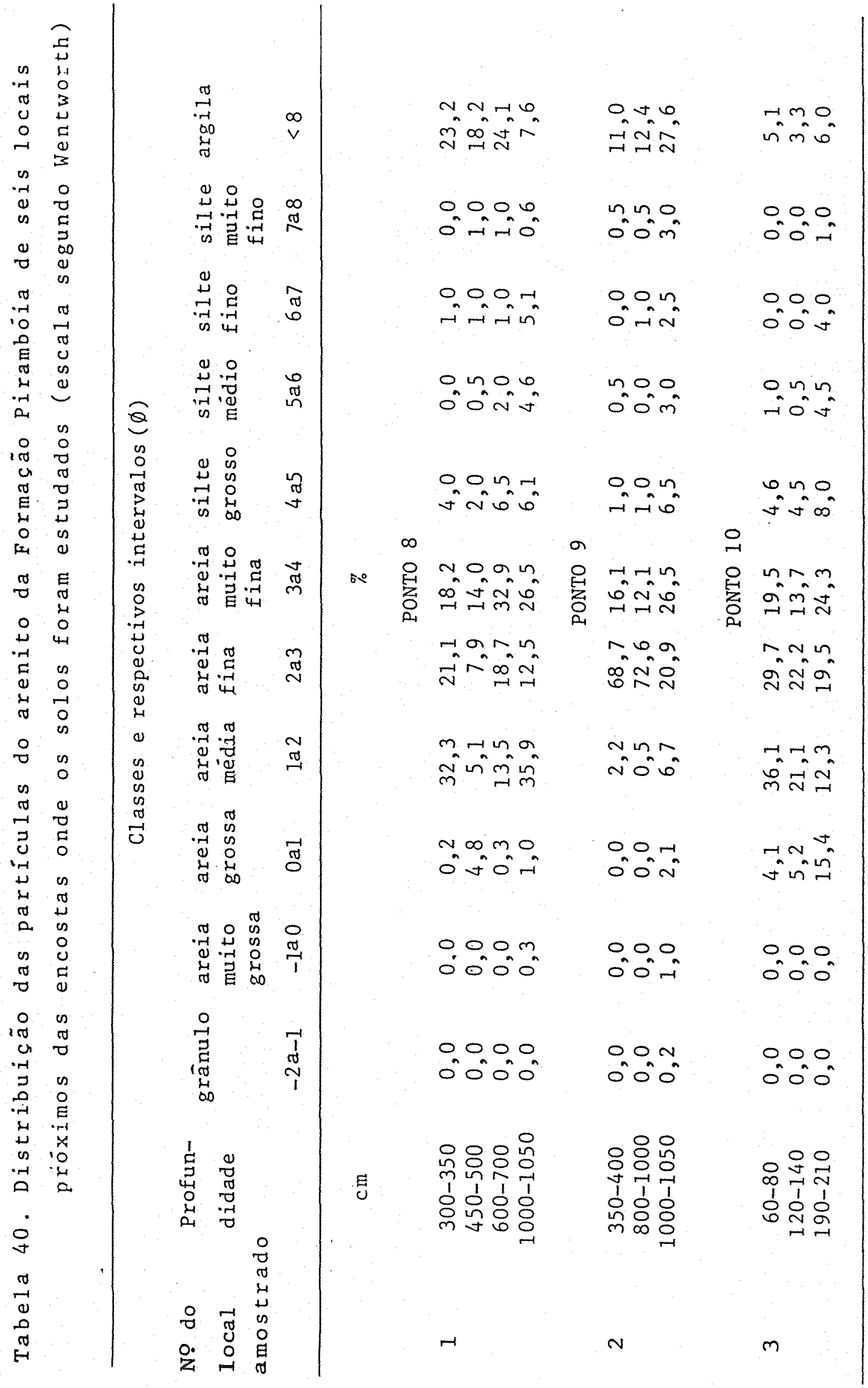




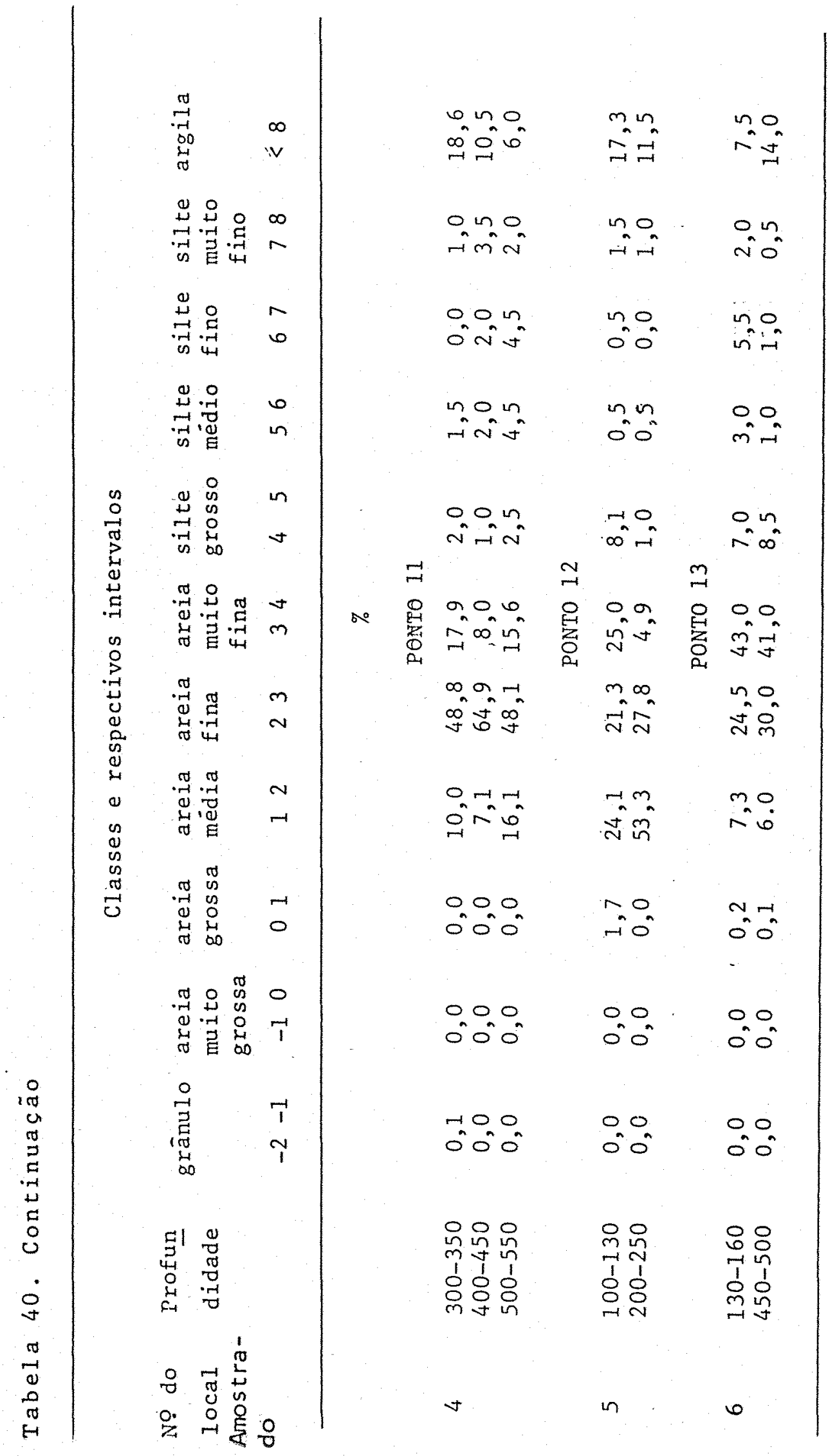




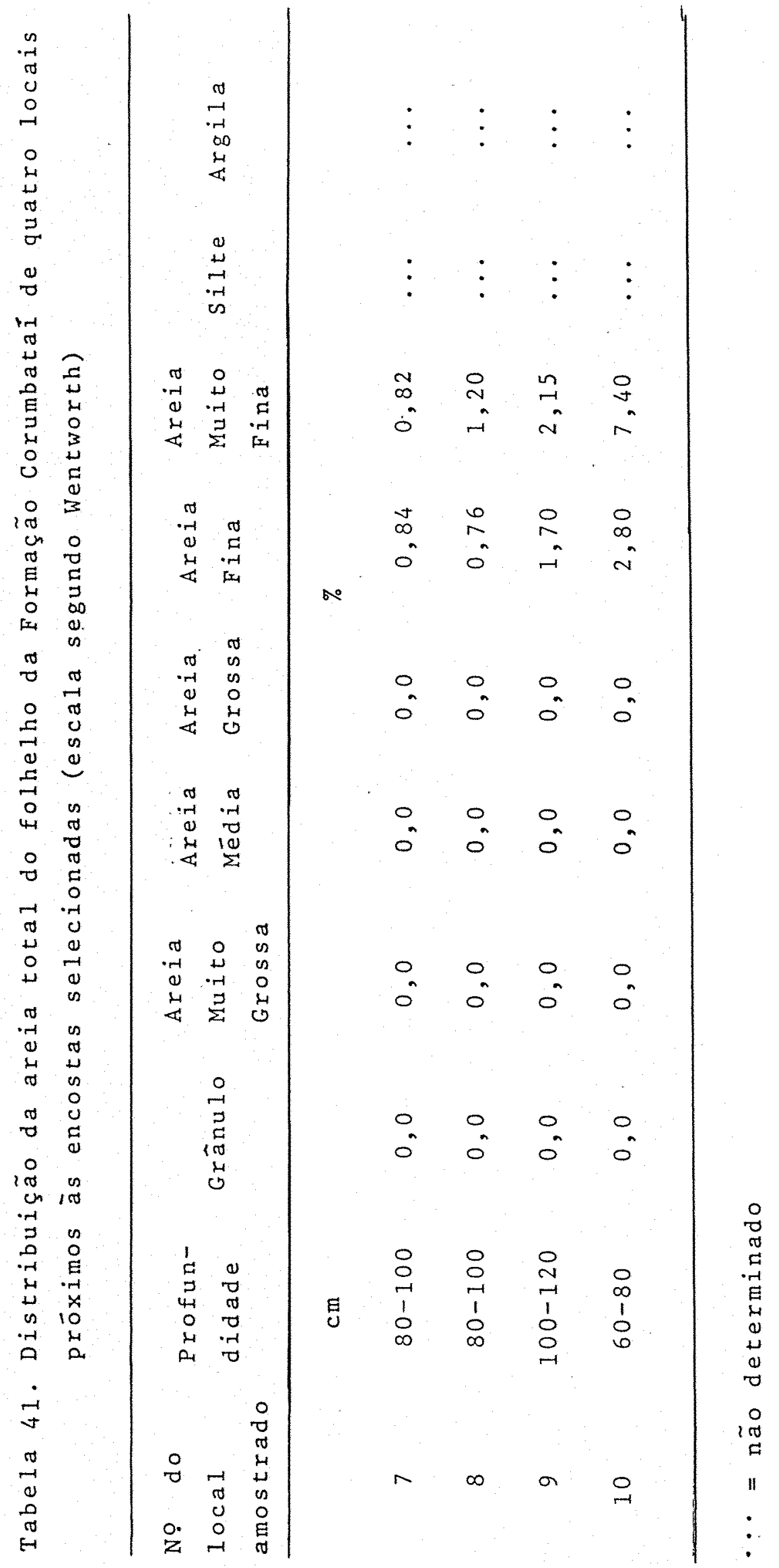




\subsubsection{Anä1ise estatística}

Foram feitos estudos estatísticos na fração areia do arenito da Formaçõo pirambóia e do folhelho da Formação Corumbataí, materiais coletados em ārea circunvizinha às encostas $A$ e $B$, para se conhecer suas caracteristicas e depois compara-las com as do PVP (perfis P4 e P7 de ambas as encostas). Verificou-se que no arenito da Formação pirambóia o valor de diâmetro médio $(M z)$ da areia tem variação de 0,11 a $0,27 \mathrm{~mm}$, o desvio padrão de 0,44 a 1,10 (bem a pobremente selecionado), o grau de assimetria de $-0,319$ a 0,600 (negativa e positiva) e a curtose de platicürtica a muito leptocūrtica) (Ta bela 42). o folhelho da Formação Corumbataí apresenta valor de diâmetro médio da fração areia variando de 0,07 a $0,18 \mathrm{~mm}$, desvio padrão de 0,26 a 0,950 (moderadamente ou pobremente selecionado), o grau de assimetria de $-0,03$ a 0,585 (negativo ou positivo) e curtose de 0,549 a 1,735 (platicürtico ou leptocü (ico) (Tabela 43).

Comparando-se as variaçōes de diāmetro mēdio da fração areia do horizonte Al do perfil p4 (0,15mm) (Tabelal5), com os do arenito da Formação Pirambäia $(0,11$ a0,27mm), (Tabe1a 42) e com os da areia do folhelho da Formação Corumbataí $(0,08$ a 0,18$)$ (Tabela 43), nota-se que o valor 0,15 do horizon te Al do perfil P4 está dentro da variação de diâmetro médio da areia obtido para o arenito da Formação Pirambóia e da variação de diâmetro médio da fração areia para o folhelhoda For 
mação Corumbataí. Portanto o valor Mz não permitiu identificar com seguraņ̧a a procedência da areia do horizonte A do perfil P 4 .

o valor de diâmetro médio da fração areia do ho rizonte Al do perfil P7 (0,19mm) (Tabela 33), situa-se dentro da variação do diāmetro médio obtido para o arenito da Formação Pirambóia $(0,11$ a $0,27 \mathrm{~mm})$ (Tabela 42) e está pröximo do l主 mite de variação do folhelho da Formação Corumbataí $(0,08$ a 0,18 ) (Tabela 43). Desse modo o diâmetro médio da fração areia, não constitui-se como bom indicador para avaliar se a areia do horizonte A do perfil P7 originou-se do folhelho ou arenito. Portanto, a comparação dos valores dos parāmetros estatísticos de materiais de uma Formação Geológica ou outra (Pirambóia x Corumbatail acima discutidos com os solos, não foram suficientemente diferenciados para identificar a origem dafração areia do horizonte A do PVP (perfis P4 a P7). 


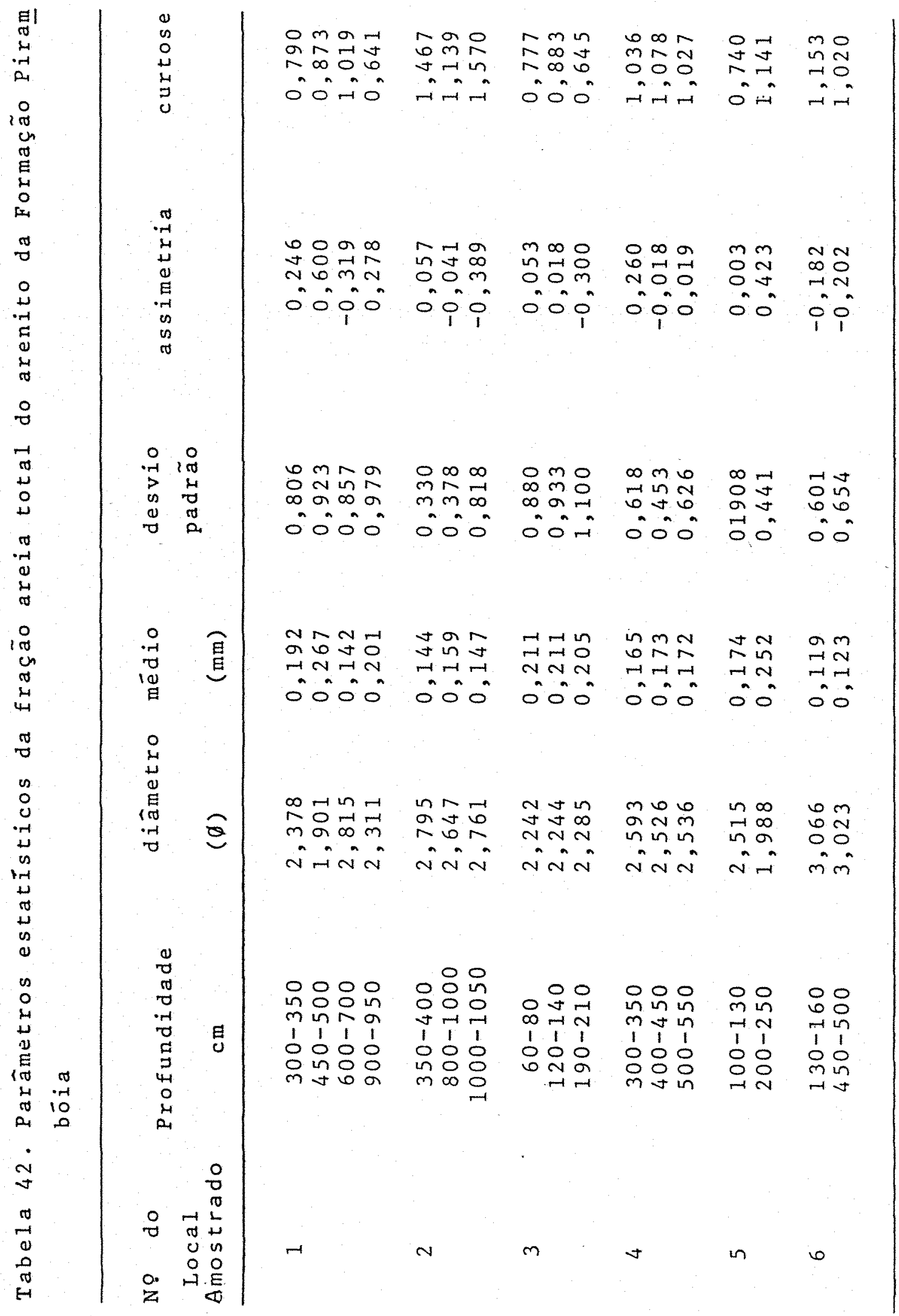




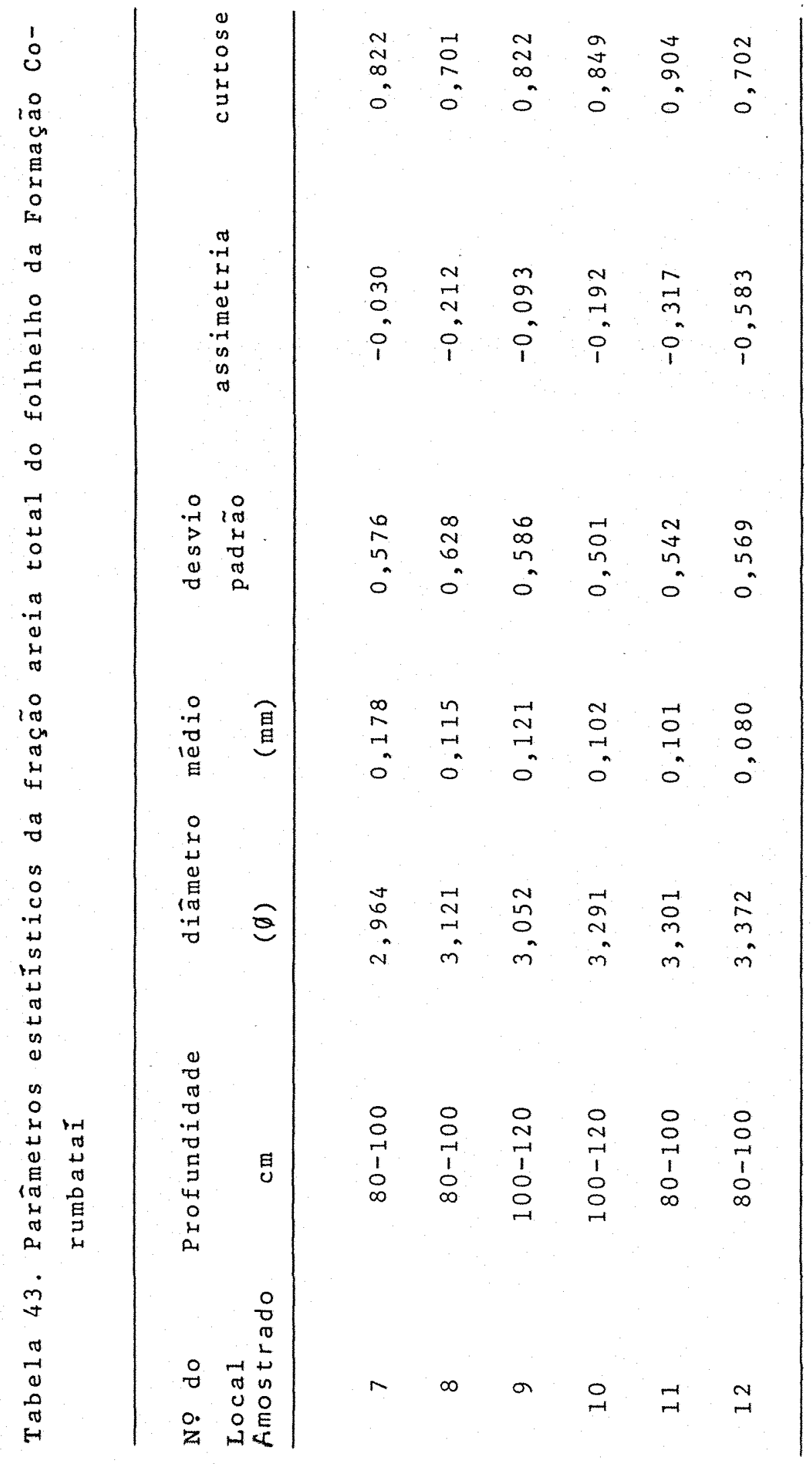




\subsubsection{Anāilise de morfoscopia}

Foram feitos estudos de arredondamento da fração areia muito fina $(0,125-0,062 \mathrm{~mm})$ no arenito da Formação Pi rambóia e no folhelho da Formação Corumbataí para efeito de com paração desses dados com os dos perfis.

Os valures de arredondamento médio do arenito da For mação pirambóia e do folhelho da Formação corumbataí coletados em ārea circunvizinha às encostas A e B são de 0,$73 ; 0,57 ; 0,55$ e 0,63 para o arenito e 0,$37 ; 0,36 ; 0,32$ e 0,39 para o folbetho (Tabela 44).

Tabela 44. Valores de arredondamento médio da areia do arenito da Formação Piramböia e do folhelho da Formação Corumbataí

\section{ARENITO DA FORMAÇÃO PIRAMBŌIA}

Amostra

1

2

3

4

0,73

0,57

0,55

0,63 
Tabe1a 44 . cont.

FOLHELHO DA FORMAÇÃO CORUMBATAI

\section{Amostra}

$\begin{array}{cccc}5 & 6 & 7 & 8 \\ 0,37 & 0,36 & 0,32 & 0,39\end{array}$

observando-se os resultados de arredondamento médio na Tabela 44 constata-se que o arenito apresenta valores mais altos do que para o folhelho.

SOARES (1973) encontrou valor de arredondamento variando de 0,6 a 0,7 nas fraçóes areia fina e média do arenito da Formação Piramböia, logo se assemelham com os valores obtidos para esse arenito, que foi estudado em área circunvizinha às encostas A e B.

A figura 18 apresenta histogramas das classes de arredondamento da fração areia muito fina do arenito da Formação Pirambóia e do folhelho da Formação Corumbataí.

os valores de arredondamento médio da areia dos hori zontes $A$ e $B$ do PVp são relativamente próximos do referido arenito não somente no horizonte A, o que esta parcialmentede acor do com a hipótese de trabalho, mas tambëm no horizonte B do PVp. 

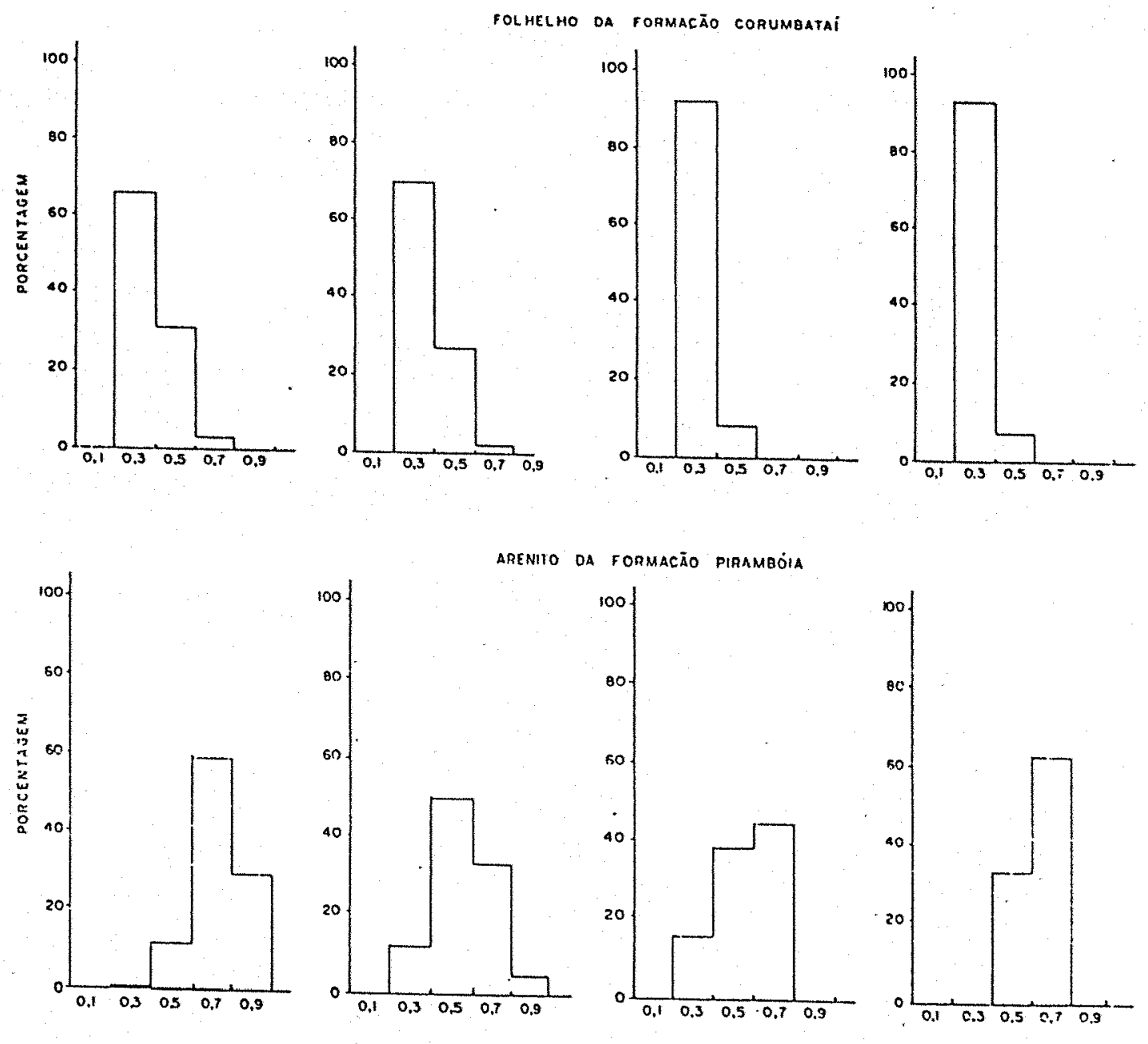

Figura 18. Histogramas da distribuição de classes de arredondamento da fração areia muito fina do folhelho da Formação Corumbataí é do arenito da Formação Piram bóia. 
5.3.4. Estudos dos minerais pesados.

Com o objetivo de se conhecer qualitativa quan titativamente os minerais pesados do folhelho da Formaçäo Corumbataí e do arenito da Formação Pirambóia, foram coletados amostras dessas rochas em local adjacente às encostas selecionadas, com o propósito de conhecer suas características e comparar com as dos solos estudados. A anälise dos minerais pesados do arenito da Formação piramböia revelou que predominam es taurolita ou zircão, conforme a profundidade (Tabela 45). Em menor quantidade ocorrem turmalina e em seguida rutilo, granada e hornblenda. Segundo wU (1981) a estaurolita é o mineral pesado mais comum no arenito da Formaçäo Pirambóiano Estado de São Paulo.

Na fração areia do folhelho da Formação Corumba taí foram encontradas baixas concentraçoes dos seguintes minerais: zircão, turmalina, estaurolita e rutilo, com predominância de zircão. 
Tabela 45. Frequências porcentuais dos minerais pesados trans parentes das amostras do arenito da formação Piram bóia do material sobrejacente de seis locais das encostas selecionadas (fração $0,125-0,062 \mathrm{~mm}$ )

\begin{tabular}{|c|c|c|c|c|c|}
\hline $\begin{array}{l}\text { Ne do } \\
\text { local } \\
\text { amostrado }\end{array}$ & $\begin{array}{l}\text { Profundidade } \\
\mathrm{cm}\end{array}$ & Zircão & $\begin{array}{l}\text { Turma- } \\
\text { Iina }\end{array}$ & $\begin{array}{l}\text { Estau- } \\
\text { rolita }\end{array}$ & Rutilo \\
\hline \multirow[t]{2}{*}{1} & $600-700$ & 48 & 28 & 24 & 0 \\
\hline & $1000-1050$ & 35 & 20 & 45 & 0 \\
\hline \multirow[t]{2}{*}{2} & $800-1000$ & 52 & 16 & 27 & 5 \\
\hline & $1000-1050$ & 51 & 32 & 17 & 0 \\
\hline \multirow[t]{2}{*}{3} & $450-500$ & 27 & 44 & 44 & 2 \\
\hline & $500-550$ & 49 & 36 & 14 & 1 \\
\hline 4 & $200-250$ & 75 & 13 & 11 & 1 \\
\hline \multirow[t]{2}{*}{5} & $130-160$ & 59 & 16 & 23 & 2 \\
\hline & $450-500$ & 67 & 18 & 12 & 3 \\
\hline
\end{tabular}


os minerais pesados da fração areia por serem qualitativamente semelhantes tanto no arenito como no folheTho e nos horizonte $A$ e $B$ do PVp não serviram para diagnosticar a contribuição de material grosseiro arenítico como cober tura, formando o horizonte A do PVP.

o parâmetro estatístico de diāmetro médio da fração areia $(M z)$, não foi suficiente para indicar a origem da fração areia do horizonte A do PVp devido a semelhança dos valores entre os horizontes $A$ e. B.

os valores de arredondamento médio da fração areia muito fina no arenito da Formação Pirambóia, que são maiores do que no folhelho da Formação Corumbataí, assemelhamse aos valores obtidos nos horizontes $A$ e B do PVP, sugerindo que esses horizontes tiveram contribuição do arenito, apesar do solo situar-se sobre ofolhelho. O horizonte C e principal 
mente a rocha (folhelho) apresenta areia com menor graude ar redondamento que nos horizontes A e B, indicando o maior retrabalhamento a que foram submetidos tanto o horizonte A como - B do PVp. Esses dados permitem afirmar que provavelmente os horizontes A $\mathrm{e}$ B do PVp, tiveram a contribuição da mesma ärea fonte (Arenito Pirambóia), tendo em vista as mesmas caracteristicas de grau de: arredondamento desse material e dos referidos horizontes.

A descrição morfológica do PVp apresentou presença de mosqueamento no topo do horizonte $B$, indicando que houve condiçóes redutoras que favoreceram o processo de destruição dos argilo-minerais em superfície.(ferrólise).

A diferença textural entre os horizontes A e B do PVp pode ser explicada, pelo menos em parte, por processos de eluviação/iluviação de argila, constatado no exame micromorfológico e na descrição morfológica (cerosidade). 


\section{LITERATURA CITADA}

BAHIA, V.G., 1973. Contribuição ao estudo da mineralogia de um LVE f. a. do Município de Iracemāpolis, SP. Dissertação apresentada à E.S.A. "Luiz de Queiróz", USP, para obtenção do titulo de mestre. $75 \mathrm{p}$.

BARSHAD, I., 1964. Chemistry of soil development. In: BEAR,F. E. (ed.). Chemistry of the soil. Reinhold, New York, pp. $250-261$.

BREWER, R.; 1968. Clay iluviation as a factor in particle-size differentiation in soil profiles. Trans. 9 th Int. Cong.Soil Sci., 4:489-499.

BRINKMAN, R.; 1970. Ferrolysis a hidromorphic soil forming process. In: Geoderma 3:199-206.

BRINKMAN, R., 1979. Ferrolysis, a soil formation process in hidromorphic conditions. Wageningen, Centre for Agricultural Publishing and Documentation. 106p. (Reports 887). 
BULLOCK, P.; M.H. MILFORD, M.G. CLINE, 1974. Degradation of argilic horizons in Udalf soils of New York State. Soil sci. Soc. Amer. Proc. 38:621-628.

BUOL, S.W.; F.D. HOLE, R.J. MCCRACKEN, 1973. SOil Genesis and classification. Iowa State. University Press, 360 .

CAMARGo, T. e P. VAGElER, 1937. Analyse de solos (II). 1. Anā lise mineralógica. Bol. Téc. no 31 do Instituto Agronómico de Campinas. $22 \mathrm{p}$.

CARVALHO, A.A.; A. CHAUVEL, e N.M.M. GONÇALVES, 1973. Alteration of basalt and formation of kaolinitic and gibbistic ma terial in the region of Ribeirão Preto (SP), Brazil. In: Pro ceeding of the "International Seminar on Laterization. Pro cesses. São Paulo, Brazil. 1982. São Paulo, USP. I. Astronô mico Geofísico, pp. 477-489.

CATANI, R.A. e J.E. PAIVA NETO, 1949. Dosagem de potásio e só dio pelo fotômetro de chama, sua aplicação em anāiise de so 1o. Bragantia, Campinas, SP . 9:175-82.

COMISST̃O DE SOLOS, 1960. Levantamento de Reconhecimento dos solos do Estado de São Paulo. CNEPA. SNPA. Miniséerio da Agricultura. Rio de Janeiro, Brasil, 634p. (Boletim 12).

DECHEN, S.C.F., 1979. Caracterização e mineralogia de solos desenvolvidos de folhelho e arenito. Tese de doutoramento. Esc. Sup. Agric. "Luiz de Queiróz", Piracicaba, 252 .

DEMATTE, J.L.I., 1970. Gênese e classificação de solos originados do grupo geológico Estrada Nova - município de Piraci caba. Tese de Livre-docência. Escola Sup. Agric. "Luiz de Queiróz", USP. Piracicaba, $123 \mathrm{p}$. 
DEMATTE, J.L.I., 1978. Zircônio e titânio da fração areia de so10. Rev. Bras. de Ciência do So10. Campinas, 2:74-77.

DEMATTE, J.L.I., 1975. Characteristics and classification of a toposequence of soils near Piracicaba, Brasi1. Tese de Phd, Ohio state University, ohio. $289 \mathrm{p}$.

EUA. 1975. Department of Agriculture Soil Taxonomy. A basic system of soil classification for making and interpreting soil surveys. Washington Soil Conservation Service. Soil Servey Staff, $754 \mathrm{p}$.

EUA. 1986. Amendments to Soil Taxonomy Part 615. no VIII. In: National Soil Taxonomy Handbook Issue. Washington.

GALHEGo, H.R., 1977. Mineralogia de solos de uma topossequência na região de contato do planalto ocidental com as cuestas Basalticas no município de Botucatu, sp. Piracicaba. ESALQ/USP. 62p. (Dissertação de Mestrado).

GAMBLE, E.E., 1966. Origin and morphogenetic relations of san dy surficial horizons of upper Coastal Plain Soils of North Carolina Ph Thesis. N.C. State University, 254 p.

GROHMANN, F. e van B. RAIJ, 1973. Influência do método de agi tação na dispersão de argila do solo. In: CONGRESSO BRASILEIRO DE CIENCIA DO SOLO, 14. Santa Maria, p.123-132.

InSTITUTO AGRONômICo, 1969. Seção de Agrogeologia. Manual para descrição de solo no campo. Campinas, SP. 48p. (Boletim $188)$. 
INSTITUTO dE PESQUISAS TECNOLOGICAS DO ESTAdO dE SÃo PAULO. 1981. Mapa geológico do Estado de São Paulo. IPT. v.2. (Mo nografia, 6).

JACKSON, M.L., 1956. Soil chemical analysis. Advanced course. Published by the author. Madison, Wisconsin. $991 \mathrm{p}$.

KARPACHEVSKI, L.0., 1960. Micromorphological investigation of the processes of leaching and podzolization of soils under forest. Pochvovedenie, 5:43-52. Apud Bibliography on Podzo lization: mineralogy and weathering, no 1003 . Commonealth Bureau of Soils. Harpenden, England.

KRUMBEIN, W.C., 1936. Application of logarithmic movements size frequency distribuition of sediments. J. Sedimentary Petrology. V.G., 35-47.

KRUMBEIN, W.C., 1938. Size frequency distribuition of sediments and the normal phi curve. J. Sedimentary Petrology.V. $8: 84-90$.

KRUMBEIN, W.C. e F.J. PETTIJOHN, 1938. Manual of Sedimentary Petrography. D. Appleton Century. N.Y. 594 p.

LEPSCH, I.F.; S.W. BUOL e R.B. DANIELS. 1977. Soil landscape relations in and area of the occidental plateau of são Pau1o, Brasil. II. Soil Morphology. Genesis and classification. Soil Sci. Soc. Am. J. 41:109-115.

LEPSCH, I.F.; C.L. ROTTA e J.M.A.S. VALADARES. 1978. Mineralo gia, classificação e formas de potāssio em solos da Estação Experimental de Pindorama (SP). Rev. Bras. de Ciência do So 10. Campinas, 2:63-68. 
LOBO, A.E.M., 1971. Descontinuidade litológica de alguns solos da região de Piracicaba, Dissertação apresentada à Esc. Sup. Agric. "Luiz de Queirōz", USP. para obtenção do título de mestre. $65 \mathrm{p}$.

MARSHALL, C.E., 1940. A petrographic method for the study of soil formation processes. Proc. Soil Sci. Soc. Amer. 5:100103.

McKEAGUE, J.A. et alii. 1978. Micromorphological evidence of illuvial clay in horizons designated Bt in the field. Can. J. Soil Sci. 58:179-186.

MEKARU, T.A. e G. UHERARA. 1972. Anion adsorption in Ferriginous tropical soils. Soil Sci. Amer. Proc., Madison,36:296300 .

MONIZ, A.C. e S.W. BUOL. 1982. Formation of and Oxissol-Ultis sol transition in são Paulo, Brazil. I Double layer water flow model of soil development. Soil Sci. Soc. J. 46:12281233.

NETTLETON, W.D.K.W. FLACH e B.R. BRASHER. 1969. Argilic horizon without clay skins. Soil Sci. Soc. Amer. Proc. $27: 78-$ 83.

PENCK, W., 1953. Morphological analysis of land forms. London, Memil1an and Co., $429 \mathrm{p}$.

PETTIJOHN, F.J., 1941. Persistance of heavy minerals and geologia age. Jour. Geo1., 49:610-625. 
PETTIJOHN, F.J., 1957. Sedimentary Rocks, 2. ed., New York, Harper nad Brothers.

PINTO; H.S.; A.A. ORTOLANI e R.R. ALFONSI. 1972. Estimativa das temperaturas médias do Estado de são paulo em função da altitude e latitude. Inst. de Geografia, USp:20p: (Ciência da Terra, 23).

PRADO, H.; J.B. OLIVEIRA e C.L.F. ALMEIDA. 1981. Levantamento pedológico semidetalhado do Estado de são Paulo: quadrícula de são Carlos, escala 1:100.000. Aerofoto Cruzeiro do Sul S/A.

QUETROZ NETO, J.P.; A. JOURNAUX; J. PELLERIN e A. CARVALHO.

1977. Formações superficiais da região de Maríia. Institu to de Geografia, Sedimentologia e Pedologia. 7, 35p.

RAIJ, B. van e M. PEECH. 1972. Eletrochemical properties of some oxisols and alfisols of the tropics. Soil sci. Amer. Proc, Madison, 36:587-593.

RAIJ, B. van e J:M.A.S. VALADARES, 1974. Anālise dos elementos maiores de rochas e solos. Boletim Técnico no 16. Insti tuto Agronômico de Campinas. $22 \mathrm{p}$.

RESENDE, M., 1983. Bruno não cālcico, interpretação de um per fi1. Esc. Sup. Agric. Mossoró, FUND. GUIMARÃES DUQUE e V.F. VIÇOSA.

RUSSELL, R.D. e R.E. TAYLOR. 1937. Roundness and shape of Mis sissipi River Sands. Journal of Geology, 45:225-267. 
SCHWERTMANN, U., 1964. Differenzierung der Eisenoxy des Bodens durch pholochemische Extracktion nuit saurer Ammoniumoxalat Losumg. A. Pflanzener nahr., Dung., Baden - Kundae. $105: 194-202$.

SCHWERTMANN, U.; W.R. FISHER e H. PAPENDORF. 1968. The influen ce of organic compounds on the formation of iron oxides. Proc. $9 t h$ Intern. Congress of Soil Sci., Adelaide, Austrä1ia. Transactions 1:645-655.

SCHWERTMANN, U.; D.G. SCHULZE e E. MURAD. 1982. Identification of ferrihydrite in soils by dissolutions kinetics, differen tial X-ray difration and Mossbauer spectroscopy. Soil Sci. Soc. Am. J., Madison, 46:869-875.

SIMONSON, R.W., 1949. Genesis and classification of Red-yellow Podzolic Soils. Soils Sci. Soc. Amer. Proc., Madison, $14: 316-319$.

SLAVIN, W., 1968. Atomic absorption spectroscopy. New York, Intercis, $307 \mathrm{p}$.

SOARES, P.C., 1973. O mesozoico gondwânico no Estado de São Paulo. Tese de Doutoramento, Rio Claro, são paulo.

SOUZA, J.J. e J.L.I. DEMATTE. 1979. Aspectos relacionados entre os solos e a paisagem da região de Iracemäpolis, Estado de säo pau1o. R. bras. Ci. Solo. Campinas, SP. 3.

SuguIo, K., 1973. Introdução e Sedimentologia. São Paulo. Ed. Edgard Blucher. Universidade de São Pau10. $317 \mathrm{p}$. 
SYS, C., 1959. The significance of clay skins certain soils of Itati (Belegian Congo). Proc.3rd Interfr. Soils Conf. $169-177$

THORNTWAITE, C.W. e J.R. MATHER, 1955. The water balance. Cen terton. N.J., Drexed Institute of Tecnology. 104p. (Publica tions in climatology, v.3, nol).

VETTORI, L., 1969. Método de anālise de solo. Rio de Janeiro, Equipe de Pedologia e Fertilidade do So10, 24p. (Boletim Técnico, 7).

WADELL, H., 1932. Volume, shape and roundness of quartz parti cles.J. Geo1., 40:443-451.

WENTWORTH, C.K., 1922. A scale of grade and class terms of clastic sediments. Journal of Geology, 30:377-392.

WU, F.T. e P. SOARES, 1974. Minerais pesados nas Formaçöes Co rumbataí e Botucatu. An. XXVIII. Congres. Bras, Geo1. 119127.

WU, F.T., 1981. Minerais pesados das sequências arenosas Paleozóica e Mesozóica no Centro-Leste do Estado de são Paulo. Tese de Mestrado. Inst. Geo1., USP : 
8. A P $\bar{E} N$ D I C E 
PERFIL - 1

Data $-05 / 11 / 84$

Classificação: Podzölico Vermelho-Amarelo, A moderado, argila de atividade baixa, ālico, textura arenosal média.

Localização: Município, Estado e Coordenadas - $2,5 \mathrm{~km}$ do la do esquerdo da estrada Ferraz - Corumbataí, SP $22^{\circ} 17^{\prime}$ s e $47^{\circ} 37^{\prime}$ WG.

Situação e declive: Topo, $5 \%$.

Altitude: $\quad 640 \mathrm{~m}$.

Litologia: Arenito

Formação Geolögica: Formação Pirambōia.

Periodo: Triāssico.

Material Originārio: Produto de decomposição de arenito.

Rochosidade: Não rochosa.

Relevo: Ondulado.

Erosão: Não aparente

Vegetação Primäria: ? 
Uso Atual: Pastagem.

Clima: $\quad$ Cwa.

Descrito e coletado por: H. do Prado.

A11 0-5cm; bruno acinzentado (7,5YR 4/2, ümido); areia; granular pequena fraca; friável, não plástico e não pegajoso; transição clara e plana.

A12 5-10cm; bruno (7,5YR 4/3, ümido); areia franca; suban gular média fraca; friävel, ligeiramente pläs tico e ligeiramente pegajoso; transição clara e plana.

A3 10-25cm; bruno ( $7,5 Y R 4 / 4$, umido); areia Eranca; suban gular média fraca; friävel, ligeiramente pläs ticoe ligeiramente pegajoso; transição clara e plana.

B1 25-45cm; 1 aranja amarelado (10YR 6/3, ümido); areia franca; subangular média fraca; friável, 1 igeiramente plástico e ligeiramente pegajoso; transição clara e ondulada.

B $21 \quad 45-60 \mathrm{~cm}$; 1aranja amarelado (10YR 6/4, ümido); franco arenoso; subangular média fraca; friävel, 1igeiramente plástico e ligeiramente pegajoso; transição clara e ondulada.

B22 60-70 cm; laranja amarelado (10YR 6/5, ümido); franco arenoso; subangular média fraca; friävel, Iigeiramente plästico e ligeiramente pegajoso; transição clara e ondulada. 
B23 70-90cm; bruno amarelado claro (10YR 7/6, ümido); fran co arenoso; subangular mëdia fraca; firme / friāvel, ligeiramente plástico e ligeiramente pegajoso; transição clara e ondulada.

B24 90-115cm; bruno amarelado claro (10YR 6/6, ümido); fran co arenoso; subangular média Eraca; firme/ friāvel, ligeiramente plästico e ligeiramente pegajoso; transição gradual e ondulada.

C1 115-130 cm; bruno amarelado claro (5YR 6/4, ümido); mosqueado comum pequeno proeminente laranja (2,5YR 6/4, úmido); franco arenoso; subangular média fraca; friável, ligeiramente plàsti ca e ligeiramente pegajosa; transição abrupta e ondulada.

C2 130-145cm; 1aranja amarelado (10YR 7/2, ümido); mosqueado comum pequeno proeminente laranja $(2,5 Y R 6 / 5$, umido); franco arenoso; 1 igeiramente plástico e 1 igeiramente pegajoso.

C3 145-160cm; coloração variegada composta de laranja amare lado (10YR 7/2, ümido) e laranja $(2,5 Y R 6 / 4$, umido); franco arenoso; 1 igeiramente plästico e 1 igeiramente pegajoso.

C4 160-180cm; vermelho acinzentado (2,5YR 6/2, úmido); mosqueado comum pequeno proeminente cinza claro (10YR 8/2); franco argilo arenoso, ligeiramen te plāstico e ligeiramente pegajoso.

C5 180-200cm; Iaranja (2,5YR 6/3, umido), mosqueado comum pe queno proeminente cinza claro (10YR $8 / 2$, ümido); Eranco arenoso; ligeiramente plästico e 1 igeiramente pegajoso. 
C6 200-220 cm; vermelho acinzentado (2,5YR 6/2; úmido); mosqueado comum pequeno proeminente cinza claro (10YR 8/2); franco arenoso; ligeiramente plä tico e ligeiramente pegajoso.

C7 220-250cm; cinza averme1hado claro (2,5YR 7/2, úmido); mosqueado comum pequeno proeminente cinza cla ro (10YR 8/2); franco argiloso arenoso; ligei ramente plástico e ligeiramente pegajoso. 


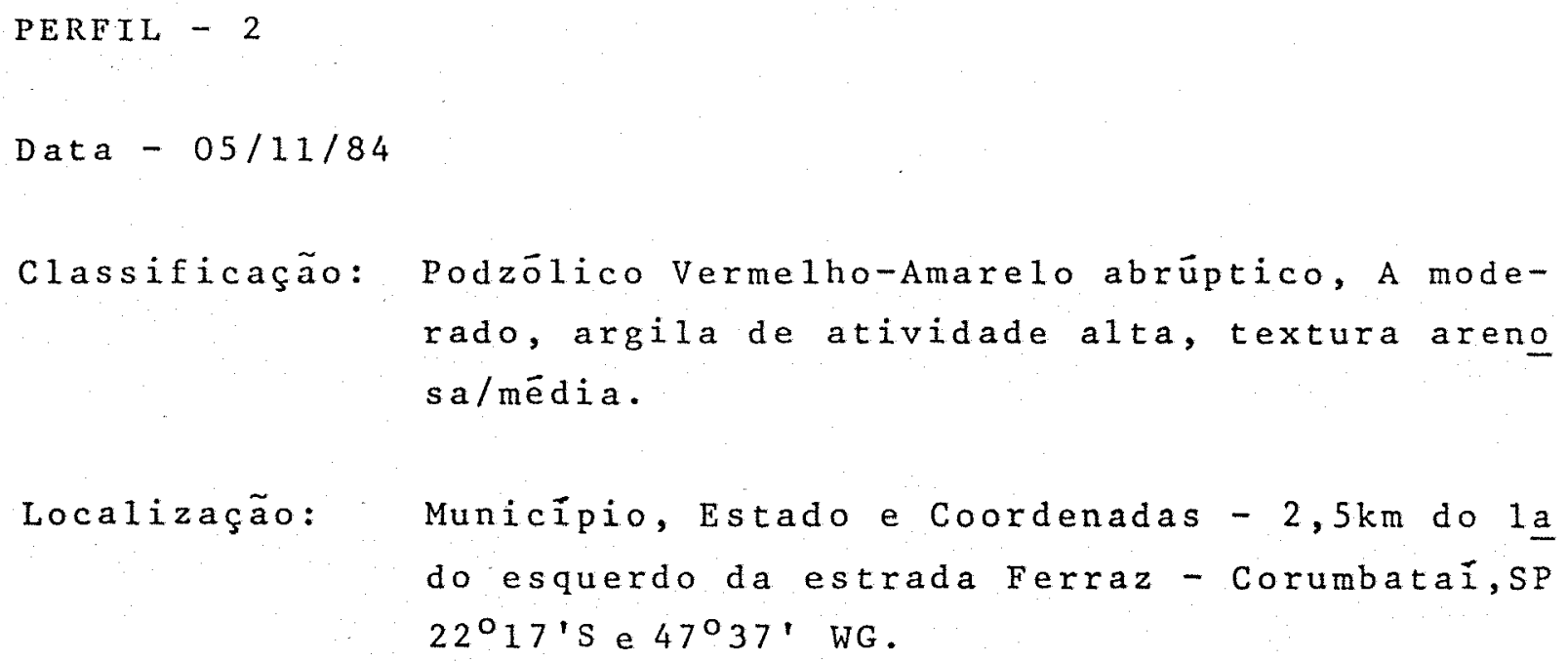

Localização: Município, Estado e Coordenadas - 2,5km do 1a do esquerdo da estrada Ferraz - Corumbataí, sp $22^{\circ} 17^{\prime}$ s e $47^{\circ} 37^{\prime}$ WG.

Situação, declive: Trincheira situada na meia encosta, com cerca de $15-20 \%$ de declive.

Altitude: $625 \mathrm{~m}$.

Litologia: Arenito.

Formação Geológica: Formação Pirambōia.

Período: Triāssico.

Material originārio: Produto de decomposição de arenito.

Rochosidade: Não rochosa.

Relevo: Ondulado.

Erosão: $\quad$ Sulcos rasos

Vegetação Primäria:?

Uso Atual: Arroz. 
Clima: Cwa.

Al1 0-7cm; bruno amarelado acinzentado (10YR 4/2, úmido) areia; grãos simples; solto, não plāstico e não pegajoso; transição clara e plana.

A12 7-18cm; bruno (7,5YR 4/3, ümido); areia; grãos simples; solto, não plástico e não pegajoso; tran sição clara e plana.

A21 18-28cm; bruno amarelado acinzentado (10YR 5/2, úmido) areia; grãos simples; solto, não plástico e não pegajoso; transição clara e plana.

A22 28-49cm; bruno amarelado acinzentado (7,5YR 5/2, ümido); areia; grãos simples, solto, não plástico e não pegajoso; transição abrupta e plana

A23 49-67cm; bruno (7,5YR 6/3, ümido); areia; grãos simples; solto, não plästico e não pegajoso; tran sição abrupta e ondulada.

B21 67-80cm; bruno amarelado (10YR 5/4, ümido); mosqueado pouco, pequeno distinto; bruno amarelado (IOYR 5/7); franco arenoso; subangular média fraca; friāvel; ligeiramente plästico e não pegajoso; transição clara e ondulada.

B22 80-90cm; bruno claro (7,5YR 5/6, úmido); mosqueado pouco, pequeno e distinto, bruno amarelado (IOYR $5 / 5)$ e pouco pequeno e distinto, bruno claro (7,5YR 5/7); franco arenoso; subangular média fraca; friāvel, ligeiramente plästico e ligeiramente pegajoso; transição clara e plana. 
B23 90-104cm; bruno (7,5YR 5/4, ümido); mosqueado pouco, pe queno e distinto, bruno amarelado (10YR 6/3); franco argilo arenoso; subangular mëdia fraca; friāvel/firme, ligeiramente plàstico e li geiramente pegajoso; transição gradual e plana.

B24 104-130cm; bruno claro (7,5YR 5/5, ūmido); mosqueado pou co, pequeno distinto, laranja amarelado (1OYR 6/3); franco argilo arenoso; subangular média fraca; friāvel/firme, ligeiramente plästico e ligeiramente pegajoso; transição gradual e pla na.

B3 130-170cm; coloração variegada composta de bruno avermeIhado claro (5YR 5/7, úmido) e laranja amarelado (10YR 7/4, ümido); franco argilo arenoso; ligeiramente plástico e ligeiramente pegą joso.

C1 170-190cm; bruno avermelhado claro (5YR 5/5, ümido):fran co argilo arenoso; ligeiramente plástico e li geiramente pegajoso.

C2 190-210cm; bruno claro (7,5YR 5/7, ümido): franco argilo arenoso; ligeiramente plästico e ligeiramente pegajoso.

C 3 210-230cm; bruno claro (7,5YR 5/6, úmido); franco arenoso; ligeiramente plästico e ligeiramente pega joso.

C4 230-250cm; bruno avermelhadoclaro (5YR 5/7, ümido); fran co arenoso; ligeiramente plästico e ligeiramente pegajoso. 
PERFIL - 3

Data $-05 / 11 / 84$

Classificação: Podzölico Vermelho-Amarelo distrófico, A mode rado, argila de atividade alta, textura areno $\mathrm{sa} / \mathrm{mēdia}$.

Localização: Município, Estado e Coordenadas - 2,5km do la do esquerdo da estrada Ferraz - Corumbataí, SP $22^{\circ} 17^{\prime}$ s e $47^{\circ} 37^{\prime}$

Situação, declive: Meia encosta, 15-25\%.

Altitude: $\quad 615 \mathrm{~m}$.

Litologia: Arenito.

Formação Geológica: Formação Pirambōia.

Período: Triàsico.

Material originärio: Produtos de decomposição de arenito.

Rochosidade: Não rochosa.

Relevo: Ondulado.

Erosão: Sulcos rasos.

Vegetação Primāria: ?

Uso Atual: Arroz 
Clima: $\quad$ Cwa.

A11 0-5cm; bruno amarelado (10YR 4/3, ümido); areia;grãos simples; solto, não plástico e não pegajoso; transição gradual e plana.

A12 5-13cm; bruno amarelado (10YR 5/3, ümido); areia; subangular mēdia fraca; não plástico e não pega joso; transição clara e plana.

A21 13-23cm; bruno amarelado acinzentado (10YR 5/2, ümido) areia; subangular média fraca; muito friável, não plästico e não pegajoso; transição abrupta e plana.

A22 23-40 cm; laranja amarelado (10YR 6/3, ümido); areia;su bangular média fraca; muito friāvel, não pläs tico e não pegajoso; transição clara e plana.

B21 40-63cm; 1aranja amarelado (10YR 6/4, ūmido); mosqueado pouco pequeno distinto, bruno avermelhado (5YR 6/5, ümido): franco argilo arenoso; subangular média moderada; firme, ligeiramente plástico e ligeiramente pegajoso; transição clara e plana.

B22 63-95cm; bruno (7,5YR 5/4, ümido); mosqueado pouco pequeno distinto, laranja amarelado (10YR 6/4, ümido); franco argilo arenoso; subangular média moderada; firme, ligeiramente plástico e 1 igeiramente pegajoso; transição clara e plana. 
B23 95-I13cm; bruno avermelhado (5YR 5/4, ümido); mosqueado pouco pequeno distinto laranja (5YR 6/6); franco argilo arenoso; subangular média fraca; firme; ligeiramente plástico e ligeiramen te pegajoso; transição difusa e plana.

C1 113-140cm; bruno averme1hado (5YR 5/5, ümido); franco arenoso; mosqueado pouco pequeno proeminente laranja amarelado (1OYR 7/2); franco arenoso; ligeiramente plástico e ligeiramente pegajoso.

C2 140-160cm; bruno avermelhado (5YR 5/4, ümido); mosqueado pouco pequeno proeminente, brunoamarelado cla ro (10YR 6/6) e cinza claro (10YR 8/1, úmido) franco arenoso; ligeiramente plástico e ligei ramente pegajoso.

C3 160-180cm; bruno avermelhado (5YR 5/5, ümido); mosqueado pouco pequeno proeminente laranja amarelado claro (10YR 6/6); franco arenoso; ligeiramente plástico e ligeiramente pegajoso.

C4 180-200cm; 1aranja (5YR 5/6, ümido); mosqueado pouco pequeno distinto (10YR 8/1): franco arenoso; 1 i geiramente plāstico e ligeiramente pegajoso.

C5 200-220cm; bruno avermelhado claro (5YR 5/7, ümido); fran co arenoso; ligeiramente plástico e ligeiramente pegajoso.

C6 220-250cm; bruno avermelhado claro (5YR 5/8, ümido); fran co arenoso; ligeiramente plästico e ligeiramente pegajoso. 
PERFIL - 4

Data $-05 / 11 / 84$

Classificação: Podzōlico Vermelho-Amarelo abrüptico ālico, A moderado, argila de atividade baixa, textura arenosa/argilosa.

Localização: Municipio, Estado e Coordenadas - 2,5km do la do esquerdo da estrada Ferraz - Corumbataí, SP $22^{\circ} 17^{\prime} \mathrm{S}$ e $47^{\circ} 37^{\prime}$ WG.

Situação, declive: Terço inferior, 15-20\%.

Altitude: $\quad 600 \mathrm{~m}$.

Litologia: Folhelhos.

Formação Geolögica: Formações Corumbatắ.

Período: Permiano.

Material Originārio: Produtos de decomposição de folhelhos com provável contribuição de material remanejado oriundo de arenitos.

Rochosidade: Não rochosa.

Relevo: Ondulado.

Erosão: Não aparente.

Vegetação Primāria: ? 
Uso Atua 1: Pastagem.

A11 0-5cm; bruno acinzentado (7,5YR 4/2, ümido); areia; granular pequena fraca; friável, näo plástico e não pegajoso; transição gradual e plana.

A12 5-10cm; bruno (7,5YR, ümido); areia; granular pequena fraca; friável; não plästico e não pegajoso; transição clara e plana.

A3 10-30cm; bruno (7,5YR 5/3, ümido): areia; subangular média fraca; friável; não plástico e não pega . joso; transição abrupta e plana.

B21 30-40cm; Iaranja amarelado (10YR 6/4, ümido); mosqueado pouco pequeno distinto amarelado claro (10YR 6/6); franco argiloso arenoso; subangular média moderada; cerosidade comum e modera da; firme; plästico e pegajoso.

B22 40-55cm; bruno ( $7,5 Y R 5 / 3$, ümido); mosqueado pouco pequeno distinto, bruno amarelado claro (IOYR 6/6); argila arenosa; subangular média modera da; cerosidade comum e moderada; firme, ligei ramente plástico e ligeiramente pegajoso;tran sição clara e plana.

B23 55-80cm; bruno (7,5YR 5/4, ümido); mosqueado pouco pequeno distinto, bruno amarelado claro (10YR 6/6); argila arenosa; subangular média modera da; cerosidade comum e moderada; firme, plástica e pegajoso; transição clara e plana. 
B24 80-102 cm; laranja (7,5YR 6/4, ümido); mosqueado pouco pequeno distinto, bruno amarelado claro (10YR 6/6); cerosidade comum e moderada/fraca; firme, plästico e pegajoso; transição clara pla na.

B25 102-135cm; bruno c1aro ( 7,5 YR 5/7, ümido); mosqueado pouco pequeno distinto, bruno amarelado claro (10YR 6/6); franco argilo arenoso; subangular média, firme, plästico e pegajoso, transição clara e plana.

B31 135-160 cm; bruno avermelhado (4YR 5/4, ümido); mosqueado pouco pequeno proeminente, bruno avermelhado claro (10YR 6/6); franco argilo arenoso; subangular média moderada; firme; plástico e pe gajoso.

B32 160-180cm; bruno (7,5YR 4/8, ümido); franco argilo areno so; ligeiramente plástico e lïgeiramente pega joso.

CI 180-200cm; laranja (5YR 6/3, ümido); mosqueado pouco pequeno distinto $(2,5 Y R 6 / 3)$; argila arenosa; 1 i geiramente plästico e ligeiramente pegajoso.

C2 200-220cm; bruno avermelhado (5YR 4/8, ümido); argila are nosa; ligeiramente plāstico e ligeiramente pe gajoso.

c3 220-250cm; coloração variegada composta de laranja (5YR 6/4, ümido) e cinza claro (7,5YR 8/1, ümido); argila arenosa; 1igeiramente plástico e ligei ramente pegajoso. 
PERFIL - 5

Data $-06 / 11 / 84$

Classificação: Podzólico Vermelho-Amarelo distrófico, A mode rado, argila de atividade alta, textura areno sa/mèdia.

Localização: Município, Estado e Coordenadas - $2,4 \mathrm{~km}$ do 1 a do direito da estrada Ferraz - Corumbataí, SP $22^{\circ} 17^{\prime}$ s e $47^{\circ} 37^{\prime} W G$.

Situação, declive: Topo $<2 \%$.

Altitude: $\quad 623 \mathrm{~m}$.

Litologia: Arenito.

Formação Geológica: Formação Pirambóia.

Período: Triássico.

Material originário: Produto de decomposição de arenito.

Rochosidade: Não rochosa.

Relevo: Suave ondulado.

Erosão: Não aparente.

Vegetação Primäria: ?

Uso Atual: Pastagem. 
Clima: $\quad$ Cwa

Descrito e coletado por: H. do Prado.

Al1 0-20cm; bruno (7,5YR 4/2, ümido); areia; granular pequena fraca; solta, não plástico e não pegajo so; transição clara e plana.

A12 20-35cm; bruno (7,5YR 4/3, ümido); areia; grãos s.imples; solta, não plästico e não pegajoso;tran sição abrupta e plana.

A21 35-55cm; bruno acinzentado (7,5YR 6/2, ümido); areia; grãos simples, solta, não plästico e não pega joso; transição difusa e plana.

A22 55-90cm; cinza brunado c1aro (7,5YR 7/2, ümido); areia; grãos simples, solta, não plástico e não pega joso; transição abrupta e ondulada.

B21 90-95cm; bruno (7,5YR 5/3, úmido); mosqueado pouco pequeno distinto Iaranja (7,5YR 6/6, ūmido); franco arenoso; subangular média fraca; friave1; 1 igeiramente plästico e ligeiramente pegajoso; transição gradual e ondulada.

B22 95-120cm; bruno (7,5YR 6/6, ümido); mosqueado pequenodis tinto, laranja (7,5YR 6/6, ümido); franco argilo arenoso, subangular média fraca; friavel, 1 igeiramente plästico e ligeiramente pegajoso; transição gradual e ondulada. 
B23 120-150cm; bruno (7,5YR 5/5, ümido); mosqueado pouco pequeno distinto, 1 aranja (7,5YR 6/6, ümido); franco argilo arenoso; subangular média fraca; friāvel, ligeiramente plästico e ligeiramente pegajoso; transição gradual e ondulada.

B3 150-170cm; laranja (7,5YR 6/4, úmido); mosqueado pouco pequeno distinto, Iaranja (7,5YR 6/4, úmido); franco argilo arenoso; subangular média fraca; ligeiramente plästico e ligeiramente pega joso; transição clara e plana.

C1 170-200cm; bruno (7,5YR 5/4, ümido); mosqueado pouco pequeno distinto, laranja amarelado (1OYR 7/4); franco arenoso; ligeiramente plästico e ligei ramente pegajoso.

C2 200-220cm; variegado composto de laranja (7,5YR 6/6, úmi do) e laranja amarelado (10YR 7/3, ümido); areia franca; ligeiramente plästico e ligeira mente pegajoso.

C3 220-250cm; variegado composto de laranja (7,5YR,6/6, ümi do) e laranja amarelado (10YR 7/4, úmido); franco arenoso; ligeiramente plástico e ligei ramente pegajoso. 
PERFIL - 6

Data- $-06 / 11 / 84$

Classificação: Podzölico Vermelho-Amarelo abrüptico, A moderado, argila de atividade baixa, textura arenos a/média.

Localização: Município, Estado e Coordenadas - 2,4km do 1a do direito da estrada Ferraz - Corumbataí, SP $22^{\circ} 17^{\prime} \mathrm{s}$ e $47^{\circ} 37^{\prime} \mathrm{WG}$.

Situação, declive: Meia encosta, 5-10\%.

Altitude: $\quad 632 \mathrm{~m}$.

Litologia: Arenito.

Formação Geolögica: Formação Piramböia.

Periodo: Triássico.

Material originärio: Produto de decomposição de arenito.

Rochosidade: Não rochosa.

Relevo: Suave ondulado.

Erosão: Não aparente.

Vegetação Primāria: ?

Uso Atual: Pastagem. 
Clima: $\quad$ Cwa.

Descrito e coletado por: H. do Prado.

Al1 0-10cm; bruno amarelado acinzentado (10YR 4/3, ümido) areia; granular pequena fraca; solta, não plas tico e não pegajoso; transição clara e plana.

A12 10-17cm; bruno amarelado (10YR 4/3, ümido); areia; subangular mẻdia fraca; muito friävel, não plás tico e não pegajoso; transição clara e plana.

A13 17-25cm; bruno amarelado (7,5YR 4/4, ümido); areia; su bangular média fraca; muito friāvel, não plás tico e não pegajoso; transição clara e ondula d a .

A21 25-35cm; bruno amarelado (7,5YR 5/3, ūmido); areia; su bangular média fraca; muito friāvel, não pläs tico e não pegajoso; transição clara e plana.

A22 35-50cm; bruno amarelado acinzentado (10YR 6/2, úmido) areia; grãos simples; solta, não plástico e não pegajoso; transição abrupta e ondulada.

A23 50-61cm; laranja amarelado (1OYR 7/2, ümido); areia; grãos simples; solta, não plástico e não pega joso; transição abrupta e ondulada.

A24 61-73cm; laranja amarelado (10YR 7/3, ümido); areia; grãos simples; solta, não plástico e não pega joso; transị̂ão abrupta e ondulada. 
B21 73-88cm; 1 aranja amarelada (7,5YR 6/4, ümido); areia; franca subangular mëdia fraca; friāve1, não plästico e não pegajoso; transição abrupta e ondulada.

B22 88-102cm; laranja amarelado (7,5YR 6/5, ümido); franco argilo arenoso; subangular média fraca, Eriavel; ligeiramente plástico e ligeiramente pegajoso; transição clara e ondulada.

B23 102-127cm; bruno amare1ado (7,5YR 5/4, ümido); franco a gilo arenoso; subangular media fraca; friävel, ligeiramente rlástico e ligeiramente pegajoso; transição clara e ondulada.

B24 127-160cm; bruno amarelado (7,5YR 5/6, ümido); franco ar gilo arenoso, subangular média fraca;friável, ligeiramente plástico e ligeiramente pegajoso; transição clara e ondulada.

Cl 160-180cm; bruno amarelado (7,5YR 5/7, ümido); franco ar gilo arenoso; 1 igeiramente plästico e ligeira mente pegajoso.

C2 180-200cm; bruno amarelado (7,5YR 5/8, ümido); franco ar gilo arenoso; ligeiramente plástico e ligeira mente pegajoso.

C3 200-220cm; bruno amarelado claro (7,5YR 6/8, ümido); fran co argilo arenoso; ligeiramente plästico e li geiramente pegajoso.

C4 220-250cm; bruno amarelado claro (7,5YR 6/7, ümido);fran co argilo arenoso; ligeiramente plástico e lí geiramente pegajoso. 
PEREIL - 7

Data $-06 / 11 / 84$

Classificação: Podzölico Vermelho-Amarelo abrüptico, A moderado, argila de atividade baixa, textura arenosa/argilosa.

Localização: Município, Estado e Coordenadas - 2,4km do 1 a do direito da estrada Ferraz - Corumbataí, SP $22^{\circ} 17^{\prime} \mathrm{S}$ e $47^{\circ} 37^{\prime} \mathrm{WG}$.

Situação, declive: Meia encosta, $10 \%$.

Altitude: $\quad 631 \mathrm{~m}$.

Litologia: Folhelho.

Formação Geológica: Formação Corumbataí.

Período: Permiano.

Material originärio: Produto de decomposição de folhelhos com provāvel contribuição de remanejado de are nito.

Rochosidade: Não rochosa.

Relevo: Ondulado.

Erosão: Sulcos.

Vegetação Primāria: ? 
Uso Atual: Pastagem.

C1ima: Cwa

Descrito e coletado por: H. do Prado.

A11 0-5cm; bruno acinzentado ( $1,5 Y R \quad 4 / 2$, ümido); areia Eranca; subangular média fraca; friāvel, não plästico e não pegajoso; transição clara e plana.

Al2 5-20cm; bruno (7,5YR 4/3, ümido): areia franca; suban gular mëdia fraca; friāvel, ligeiramente pegajoso; transição abrupta e plana.

B21 20-30cm; bruno (7,5YR 5/4, úmido); mosqueado pouco pequeno difuso, laranja $(7,5 Y R 6 / 6)$; franco are noso; subangular média fraca; cerosidade comum e moderada; friāvel, ligeiramente plástico e Iigeiramente pegajoso; transição clara e plana.

B22 30-50cm; bruno ( $7,5 Y R 5 / 5$, ümido); mosqueado pouco pequeno difuso, 1 aranja $(7,5 Y R$ 6/6); franco argilo arenoso; subangular mēdia forte; cerosidade comum e moderada; ligeiramente plástico e ligeiramente pegajoso; transição gradual e plana. 
B23 50-80cm; bruno c1aro (7,5YR 4/5, ümido); mosqueado pou co pequeno difuso, Iaranja $(7,5 Y R 6 / 6)$; argila arenosa; subangular média forte; cerosidade comum e moderada/fraca, firme, ligeiramente plástico e ligeiramente pegajoso; transição gradual e plana.

B24 80-95cm; bruno claro (7,5YR 5/7, ümido); argila arenosa; subangular média forte; firme, ligeiramen te plástico e ligeiramente pegajoso.

C $\quad 95-115 \mathrm{~cm}$ 